DOI https://doi.org/10.30525/978-9934-26-085-8-20

\title{
INCREASING OF DURABILITY \\ OF OIL AND GAS CENTRIFUGAL PUMPS MECHANICAL SEALS USING TUNGSTEN-FREE CERMETS BASED ON CHROMIUM CARBIDE
}

\section{Prysyazhnyuk P. M., Shihab T. A., Shlapak L. S., Ivanov O. O.}

\section{INTRODUCTION}

In Ukraine, the overwhelming majority of oil and gas equipment is foreign production. And its operation is carried out in difficult working conditions, which is accompanied by a complex influence of factors such as aggressive environment, abrasive wear and high specific loads, which cause intense wear of working surfaces of parts, therefore, there is a need for import of spare parts requiring significant financial costs. Friction couplings of centrifugal pump seals are one of the most striking examples of such parts, since when they fail, the replacement sealing rings are expensive, given that the price of the seal is $\sim 20 \%$ of the cost of the pump. At present, the rings of mechanical seals are made of ceramic materials or tungstenbased cemented carbides. The essential disadvantage of ceramic rings is their low resistance to thermal cracking under dry friction that occurs at the initial stage of the pump operation or in the absence of a working environment due to improper operation. Tungsten cemented carbides are more resistant to thermal cracking, but their corrosion resistance is low and the cost is relatively high. Therefore, a rational way to increase the reliability of the mechanical seals by ensuring resistance to thermal cracking of the rings is a reasonable choice of materials for their manufacture.

Materials that are perspective for the manufacture of mechanical seals are, in particular, tungsten-free metal ceramic composites containing refractory compounds of groups IV-VI of the periodic system of elements and a viscous metal matrix phase. High resistance to thermal cracking can be achieve by using corrosion-resistant alloys based on copper as a matrix phase. One of the alloys with such characteristics is a disperse hardening copper-nickel-manganese alloy (of the brand MNMts 60-20-20), which, due to the low melting point, is technologically suitable for the manufacture of rings of mechanical seals from composites by powder metallurgy and surfacing of molten additive alloy. An important feature of this alloy is that under the conditions of prolonged temperature influence, 
which occurs when the rings of the mechanical seals are rubbed, it increases the level of its mechanical properties due to artificial aging, which allows to provide high wear resistance of the friction pairs.

Thus, the development of technology for the manufacture of mechanical seal rings from metal-ceramic composites with a matrix based of manganese cupronickel and the determination of heat propagation during their operation in conditions of dry friction is an urgent task for the oil and gas industry. The solution of which will significantly improve the reliability of mechanical sealing devices.

\section{The problems of using ceramic and composite materials for mechanical face seals design}

Mechanical seals are widely used in the oil and gas industry to seal the centrifugal pump shafts. The reliability of the end seal is one of the defining characteristics of the pump's performance, since according to statistical ${ }^{1}$, almost $70 \%$ of repair work on the rehabilitation of centrifugal pumps is associated with failure of the sealing elements for a number of reasons (fig. 1.1). This leads to the forced stopping of technological lines and, as a result, significant economic costs. In addition, the leakage of the medium that is pumped due to the loss of sealing of the sealing elements leads to environmental pollution and, accordingly, additional financial costs associated with the disposal of hazardous substances. In view of this, considerable attention is paid to the materials of the sealing elements in the pumps of the leading manufacturers, so their value reaches $20 \%$ of the cost of the pump ${ }^{2}$.

Despite the large number of constructional designs ${ }^{3}$, the typical design of the mechanical seal (fig. 1.2) involves the presence of movable and fixed rings that seal the surface perpendicular to the surface of the shaft, the metal elements provide for fixing and clamping the rings. When the shaft is rotating on the contact surfaces of rings in the gap in the width of $0.5-2 \mu \mathrm{m}^{4}$, due to the heat generated by the friction, conditions are created for changing the composition of the working environment and its evaporation.

${ }^{1}$ OOO «Гидромаш Инжиниринг». URL: http:/gme.in.ua/torcevye-uplotnenijaprichiny-vyhoda-so-stroja-v-nasosah (дата звернення: 15.11.2018).

2 Преимущества торцевого уплотнения над сальниковым. URL: http:// www.sealtd.com.ua/tor/advantage.html (дата звернення: 15.12.2018).

3 Jane Wang Q., Yip-Wah Encyclopedia of tribology:monography. New York : Springer-Verlag, 2013. 4139 p.

4 Кондаков Л.А. Уплотнения и уплотнительная техника: справочник [2-е изд.]. Москва : Машиностроение, 1994. 448 с. 


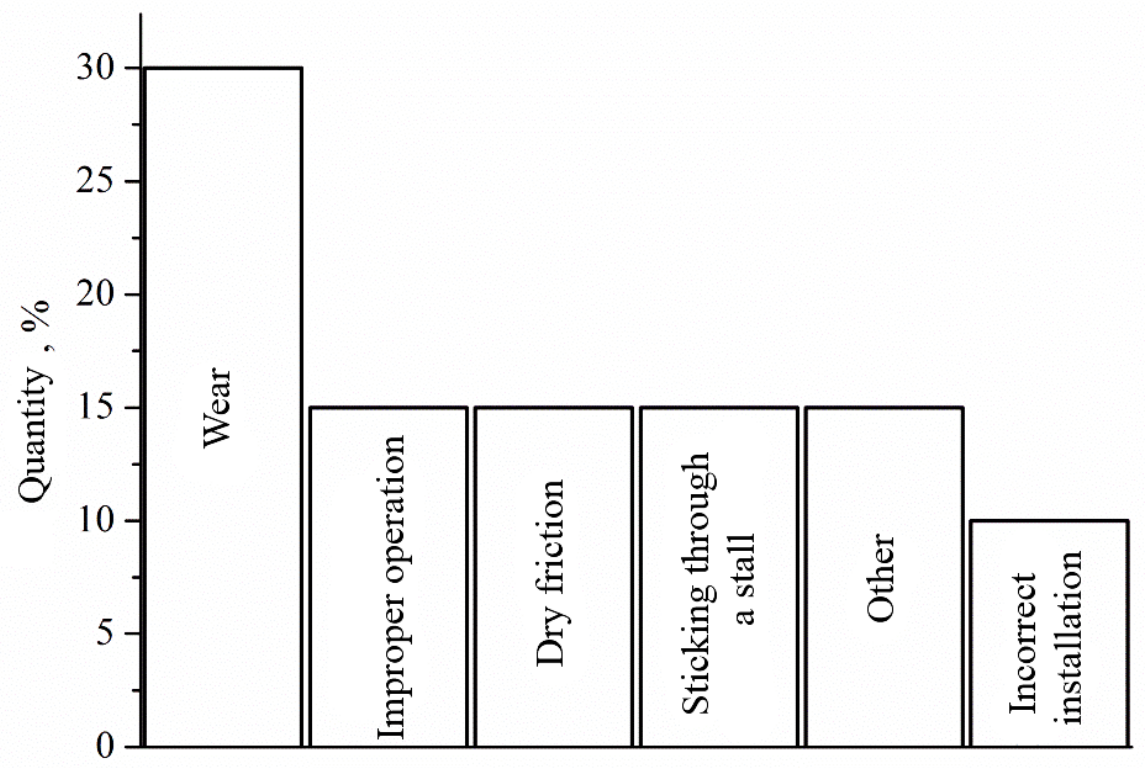

Fig. 1.1. Causes of failure of the mechanical seals

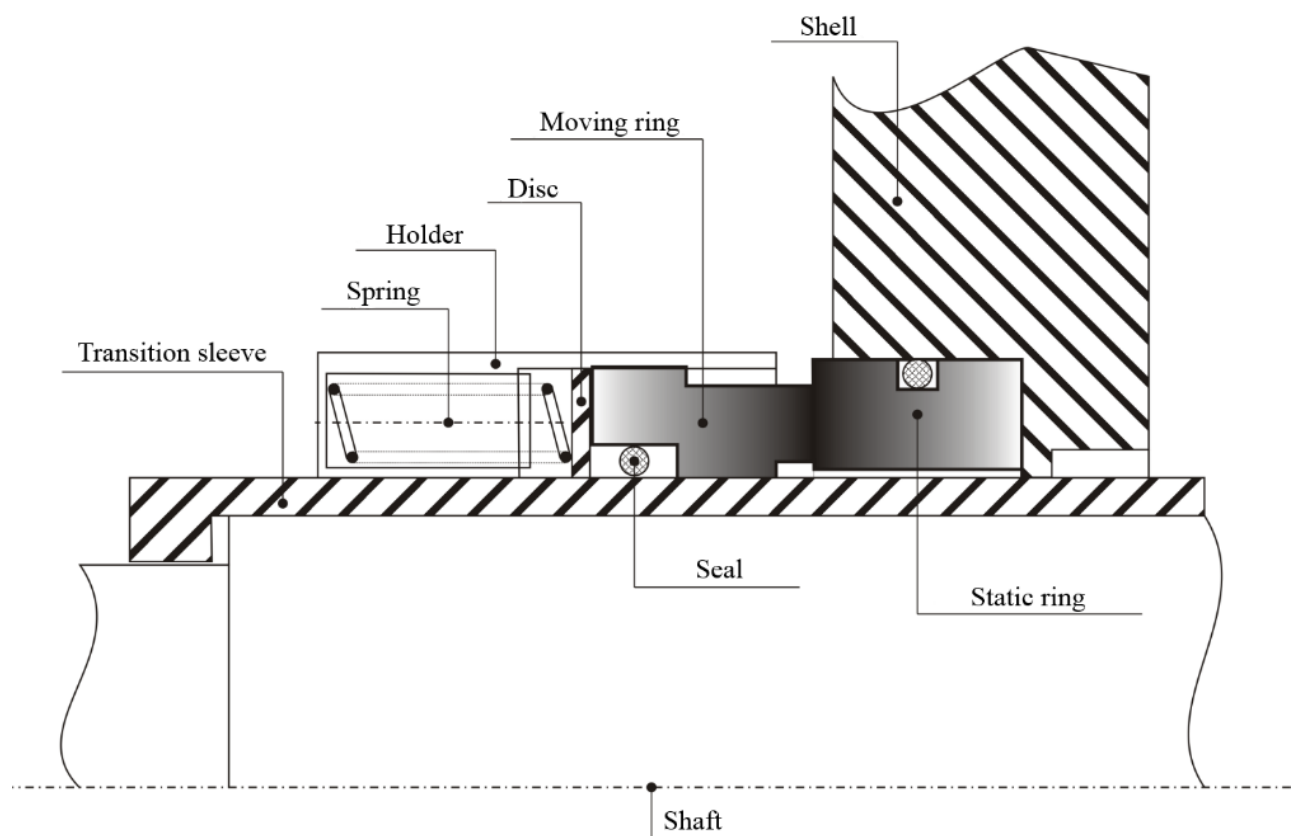

Fig. 1.2. Scheme of the typical design of the mechanical seal

Thus, for the characteristic of the stress conditions of the mechanical sealers, a parameter is used which represents the product of the pressure of the working medium $p$ on the average sliding velocity $v$. Depending on the value of the parameter $p v$ the seals according to the classification proposed by the Mayer ${ }^{5}$ are divided into four categories (table 1.1).

5 Майер Э. Торцовые уплотнения (пер. с нем.): монография. Москва : Машиностроение, 1978. 288 с. 
Classification of mechanical seals by parameter pv

\begin{tabular}{|c|c|c|c|c|}
\hline Category & $p, \mathrm{MPa}$ & $v, \mathrm{~m} / \mathrm{s}$ & $p v, \mathrm{MPa} \cdot \mathrm{m} / \mathrm{s}$ & Parameter \\
\hline I & 0,1 & 10 & 1 & Low \\
\hline II & 1 & 10 & 5 & Middle \\
\hline III & 5 & 20 & 50 & High \\
\hline IV & 5 & 20 & 50 & Highest \\
\hline
\end{tabular}

Depending on the environment being pumped in accordance with ${ }^{6}$, the seals are divided into four groups: 1) seals for non-aggressive environments (water, petroleum products); 2) seals for aggressive environments (acids, alkalis, products of the petrochemical industry); 3) seals for environments with a high content of solid particles (ground water, drilling mud); 4) special sealing.

The most common mechanical seals of pumps is the single. As a friction pair, depending on the purpose, different materials are used: chromium-nickel or chromium-nickel-molybdenum heat-treated steels in pairs with siliconized graphite or ceramics, carbon steel - with babbit, steel of type $30 \mathrm{Kh} 13$ - with wear and corrosion resistant steam (both elements of siliconized graphite). As the secondary sealing element in the mechanical seals, widespread ring welded circular cross sections were obtained. This is due to the simplicity of their shape, high tightness and reliability.

However, in some cases, the radial axial movement of the friction pair worsens due to the adhesion of sealing rings of rubber with metallic conjugated surfaces. This in most cases manifests itself after a long idle pump.

The schematic diagram of the mechanical seal is shown in fig. 1.3. The friction pair is formed by two sealing rings: the support 2, which is tightly fixed to the shaft (fig. 1.3, a), or the housing (fig. 1.3, b), and floating, or resistant, 3 which has the ability to axially move along the housing 5 (fig. 1.3, a) or shaft 1 (fig. 1.3, b) and is pressed against the support elastic element 4.

The effectiveness of the device is determined by the stability of the contact in the friction pair, and durability - the wear resistance of the steam elements and the ability of the elastic element to compensate for the wear.

${ }^{6}$ Голубев А.И. Торцовые уплотнения вращающихся валов : монография. Москва : Машиностроение, 1978. 212 с. 
In the design of structures on the basis of this scheme, the latter is subject to complications (introducing additional elements such as clamps, adjusting pads, auxiliary seals, etc.) in order to create high-performance seals that can operate in wide ranges of pressure, velocity, temperature, or simplification (combine some items) to get cheap and compact devices.

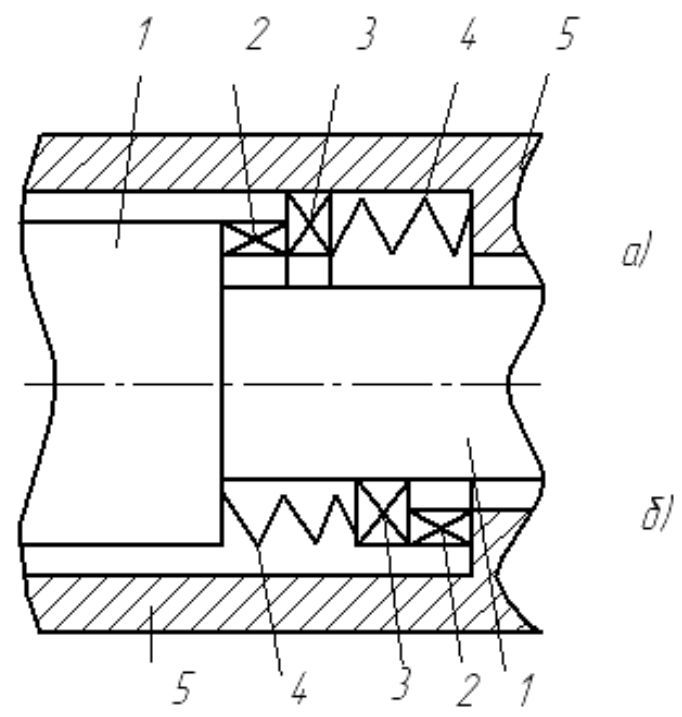

Fig. 1.3. The principle diagram of a single mechanical seal $a$ - with a fixed elastic element; $b$ - with a movable elastic element; 1 st shaft; 2 - support sealing ring; 3 - thrust sealing ring; 4 - elastic element; 5 - the case

Figure 4 shows the most common designs of the seals. All seals include the following basic elements: a thrust (floating) sealing ring 4, pressed with a screw spring 6 , a bearing seal ring 3 , a shaft 1 , and a body frame 2.

In addition to the main in the design included a number of auxiliary elements: to prevent the leakage of the surface of the axial slip of the thrust ring installed auxiliary sealing - rubber ring 5, to exclude the turn, the thrust ring is fixed pin 8 , the force and operating stroke of the spring adjusting lining 7 .

The difference between the designs is that in the compaction in fig. 1.4, a, elastic and floating sealing elements are connected with the case and are immobile, then in the compaction on fig. 1.4, b, these items are rotated along with the shaft. It should be noted that the second construction is more widespread. Its main advantage - smaller overall dimensions of several elements, the lack of - the impact of centrifugal forces on the efforts of the spring. 
In all cases, the node is located inside the case. This implies that the pressure in the cavity exceeds the ambient pressure $(\Delta p>0)$. The contact pressure in the pair of rings is created both as a result of the spring action, and due to the pressure of the sealing liquid on the end of the floating ring. Since the stable and long work of the seal is provided: $0.27>\left|\mathrm{p}_{\mathrm{k}}-\Delta \mathrm{p}\right|>0,07 \mathrm{MPa}$, a similar circuit is most appropriate in terms of the selection of an elastic element. Similarly, when the ambient pressure exceeds the pressure in the cavity $(\Delta p<0)$, it is more profitable to use the external placement of the node. External placement of the site is often used and positive, but small denoted $\Delta \mathrm{p}$, if as an elastic element choose a sufficiently rigid spring. As can be seen from Fig. 4, the pressure of the sealing liquid on the end of the floating ring is determined by the ratio $\left(d_{22}-d_{23}\right) /\left(d_{22}-d_{21}\right)$, where $d_{1}, d_{2}-$ respectively, the internal and external diameters of the contact zone; $d_{3}-$ the diameter of the contact area of the auxiliary (radial) seal.

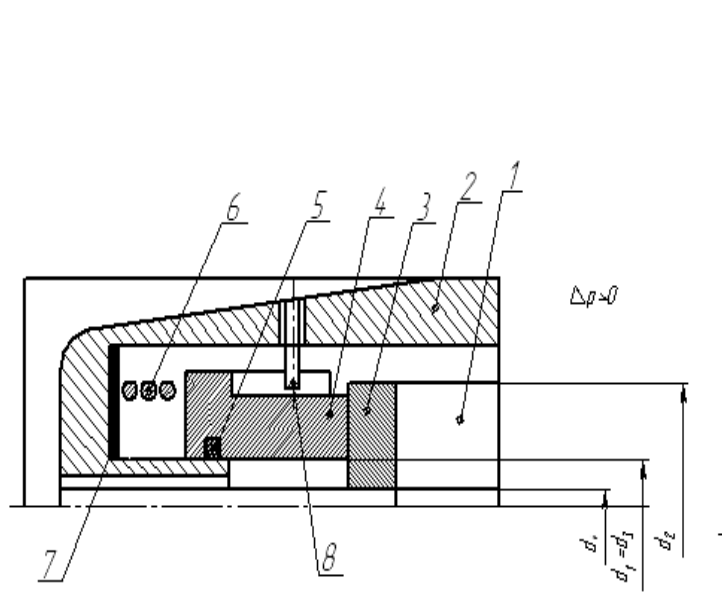

a)

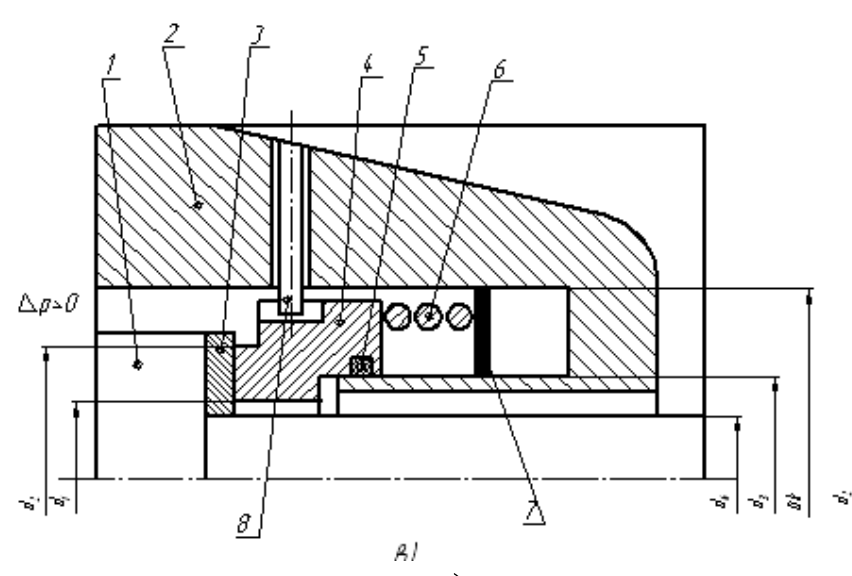

c)

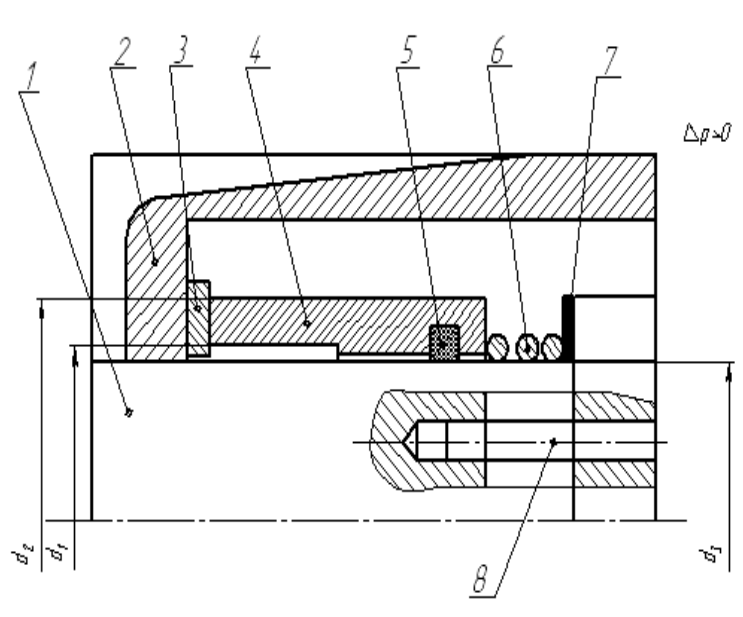

b)

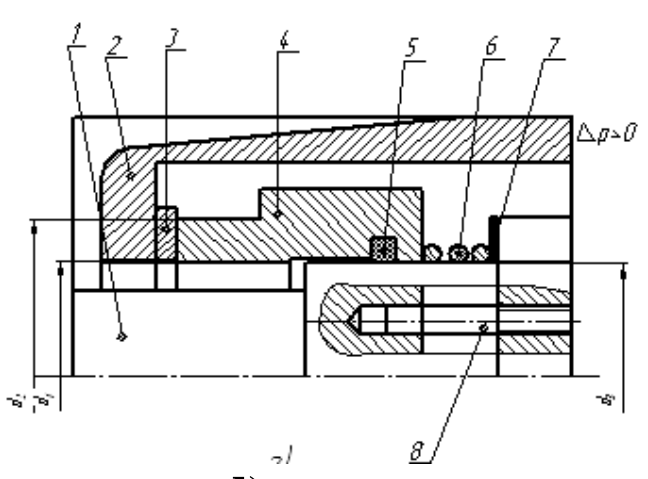

d)

Fig. 1.4. The most common schemes for assembly of seals 
By changing the ratio of the sizes $\mathrm{d}_{1}, \mathrm{~d}_{2}, \mathrm{~d}_{3}$, we can provide the optimal value of pk. For example, it is desirable to reduce the diameter $d_{2}$ in comparison with the diameter $\mathrm{d}_{3}$ at high pressures of the sealing liquid.

Unloaded seals provide more reliable sealing, but they quickly heat up and fail.

The force of the spring, which presses the sealing ring, does not have a significant effect on the work of the compression under pressure, since its strength is low, in comparison with the pressure of the liquid. The spring must move the sealing ring on the shaft to the stop.

Structurally, the diameters are regulated using stepped floating rings. In fig. $4 \mathrm{c}, \mathrm{d}$ variants of such "unloaded" seals corresponding to variants of seals shown in fig. 4, a, b. with a complete analogy of both structures in general and individual elements, with the exception of thrust rings, seals, shown in fig. $4 \mathrm{c}, \mathrm{d}$, able to withstand considerably larger pressures or at even pressures, have a higher durability.

One of the shortcomings of the end seals is the need for careful treatment of the surfaces of the friction pair. In this case, additional elastomeric elements are often used to fasten the sealing rings, which allow minor movements of the rings to compensate for the nonparallelism of the ends of the conjugated parts.

Typically, three parameters are used to characterize the operation modes of the end seals: $\mathrm{MPa}$;

- $\mathrm{p}$ - the pressure difference between the sealing and environment

- $v$ - velocity of sliding in the contact area, $\mathrm{m} / \mathrm{s}$;

- pv - product of the first two values of $\mathrm{MPa} \cdot \mathrm{m} / \mathrm{s}$. Operating conditions are determined by the temperature, nature and composition of the sealing and environment.

The mechanical seals are capable of withstanding a sufficiently high pressure. There are known examples of their use for separating cavities with a pressure drop of $\mathrm{p}=44 \mathrm{MPa}$.

When applying liquid lubricant to the rolling surface of the bearing under pressure, often the pressure in the cavity of the support exceeds the pressure of the environment. Typically, in such cases, the pressure difference is small, so for the lining of the lubricant in the cavity apply mechanical seals of general purpose or simplified.

During constructing the mechanical seals for operation at $\mathrm{pv}>100$ $\mathrm{MPa} \cdot \mathrm{m} / \mathrm{s}$, the following principles should be observed:

1) it is desirable to design the unloaded seal; 
2) sealing rings must be made of materials with maximum wear resistance, as well as with increased strength to prevent power and temperature deformation;

3) the elastic elements should be selected with a large work (preferably in the form of screw springs), which ensures stable contact in the pair;

4) auxiliary seals are made in the form of rubber circles, and in more appropriate cases, in the form of conical rings of fluoroplastic-4. such rings are better withstand pressure than membranes and bellows;

5) for $\mathrm{pv}>49 \mathrm{MPa} \cdot \mathrm{m} / \mathrm{s}$ it is expedient to apply hydrodynamic, and at $\mathrm{pv}>98 \mathrm{MPa} \cdot \mathrm{m} / \mathrm{s}-$ hydrostatic seals;

6) at $\mathrm{p}>19 \mathrm{MPa} \cdot \mathrm{m} / \mathrm{s}$, or if necessary, to reduce the leakage, if necessary, double mechanical seals, in which the elastic element, installed between the two sealing rings, by pressing them, provides contact with the corresponding rings, often supply a "shut-off liquid" - plastic lubrication is a liquid lubricant under pressure, exceeding $\mathrm{p}$;

7) at $p>9.8 \mathrm{MPa}$, it is recommended to use multi-stage mechanical seals - a set of elementary seals, uniform pressure distribution between which are carried out by special throttling units or as a result of involuntary leakage.

Fig. 5 shows the end seal, designed considering the stated principles for operation at $\mathrm{p} \leq 7 \mathrm{MPa}$. The elastic element is a multifilament screw spring 3 . The seal of the axially mobile connection of the floating sealing ring 5 and the shaft 1 is carried out with the help of a conical ring 4 . The friction pair is unloaded due to the step form of the ring 5, which is made of fluoroplastic F4K20. The bearing ring 6 is pressed into the body. The connection of the ring and the body is sealed with a gasket 7 .

Mechanical sealing devices have the highest high-speed boundary among the seals of the contact type. Known examples of their operation at circular slip speeds in a friction pair of up to $100 \mathrm{~m} / \mathrm{s}$. High sliding velocities are typical for rolling bearings of gas turbines, turbochargers, some generators, etc. ${ }^{7}$

Mechanical seal, shown on fig. 6 , intended for operation at a relative speed of moving rings 1 and $3 v=62 \mathrm{~m} / \mathrm{s}$. To reduce the slip speed, a freely rotating intermediate ring is installed. 2 . An elastic element - a set of screw springs 4 placed in a glass 6 , which is rigidly fastened to the housing 8 . An auxiliary seal that prevents leakage into the connection of

${ }^{7}$ Alan O. Lebek Principles and design of mechanical face seals : monography. New York : Wiley-Interscience, 1991. 764 p. 
the glass and floating ring, is made in the form of a rubber ring of circular cross section. The floating ring is fixed from the turn in the glass with a bolt 9 . The bearing ring is fixed to the shaft by bolt 11 .

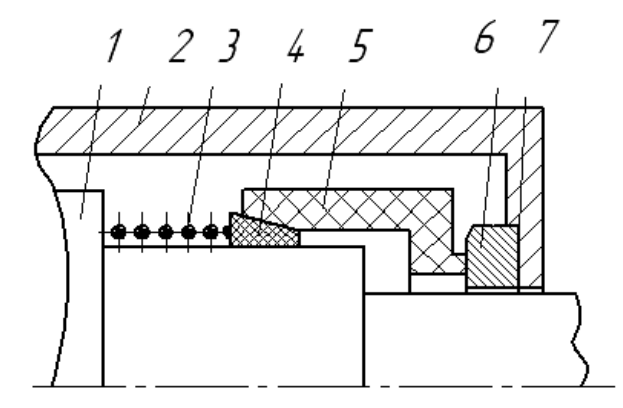

Fig. 1.5. Mechanical seal for high pressures

1 - shaft; 2 - body; 3 - a spring; 4 - auxiliary sealing with PTFE; 5 - rotary sealing ring; 6 - support sealing ring; 7 -PTFE gasket

The temperature range of the sealing devices is provided by the selection of materials and at present is $-200 \ldots+450{ }^{\circ} \mathrm{C}$.

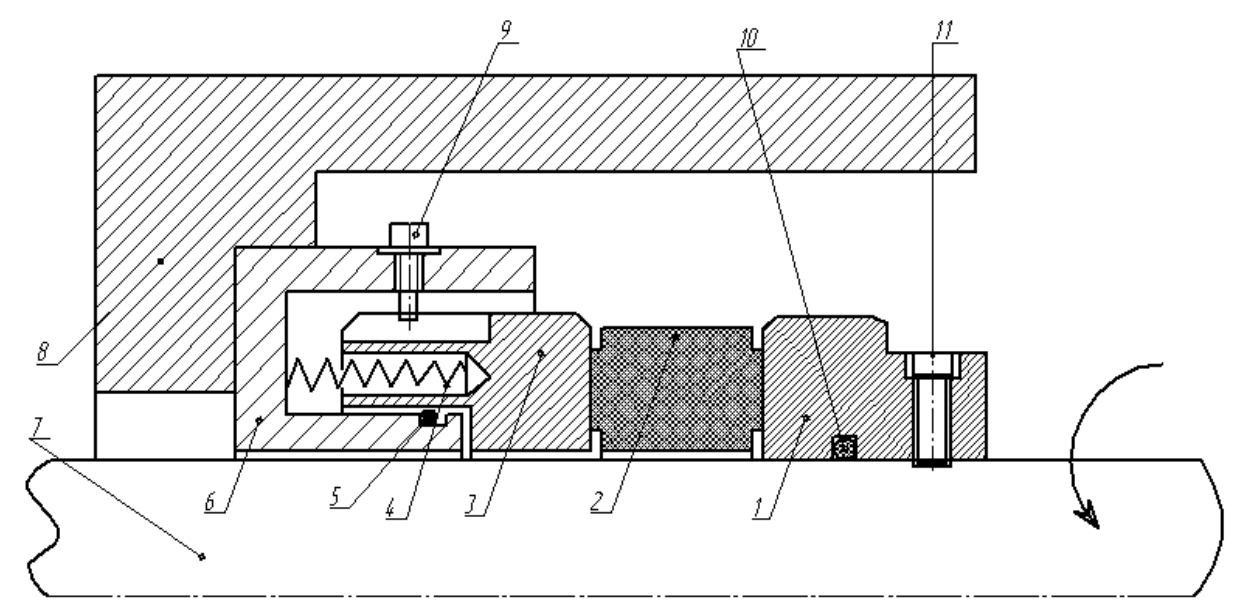

Fig. 1.6. Mechanical seal with intermediate sealing ring

1 - supporting sealing ring; 2 - an intermediate ring; 3 - thrust sealing ring;

4 - a set of springs; 5 - auxiliary sealing; 6 - a glass; 7 - shaft; 8 -case

At high temperatures $\left(\mathrm{t}>150{ }^{\circ} \mathrm{C}\right)$, metallic bellows, which serve both elastic elements at the same time, are used as an auxiliary sealing element. If $\mathrm{t} \leq 150{ }^{\circ} \mathrm{C}$, it is possible to apply conical rings of fluoroplastic-4.

An example of a seal that is operated under high temperatures can be a seal, as shown in fig. 7. Such a seal can also be used for working conditions at high temperatures. The elastic element is a set of plate springs. The sealing rings 8 and 10 are separated by two intermediate rings 9 . For self-assembly, the support ring 10 is connected to a shaft on a spherical 408 
surface that is sealed with a rubber ring 12 . The retaining ring 8 , the auxiliary ring 7 and the elastic member are fixed. Considering the increased heat dissipation in the friction zone, the auxiliary seal is made of fluoroplastic-4 in the form of a ring of conical section. The device is assembled in a glass 3 , the outer surface of which is equipped with ribs that increase the heat output. In the gap between the body 6 and the glass, a cooling fluid circulates.

The environment of aggressive nature (acid, alkali, saline solution, etc.) usually surrounds rolling bearings that are exploited in the chemical and related industries.

Mechanical seal, pictured on fig. 1.8 is designed to contain various aggressive liquids in chemical and technological equipment. Limit parameters: $\mathrm{p} \leq 0.24 \mathrm{MPa} ; \mathrm{pv} \leq 4.9 \mathrm{MPa} \cdot \mathrm{m} / \mathrm{s}, \mathrm{t}<80{ }^{\circ} \mathrm{C}$. elastic sealing element - screw spring 6 , closed in a plastic sheath to protect against leakage. Auxiliary seal - bellows 5 from fluoroplast-4, connected with sealing ring 4 and support sleeve 7 metric thread.

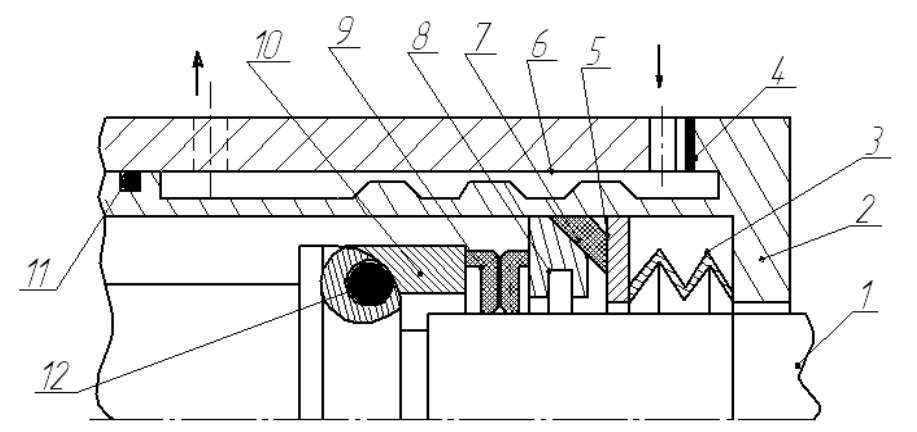

Fig. 1.7. High-speed sealing

1 -shaft; 2 -a glass; 3 - plate spring; 4 - gasket; 5 -washer; 6 -body; 7 - PTFE auxiliary sealing ring; 8 - thrust ring; 9 - an intermediate ring;

9 - support ring; 10 - rubber rings

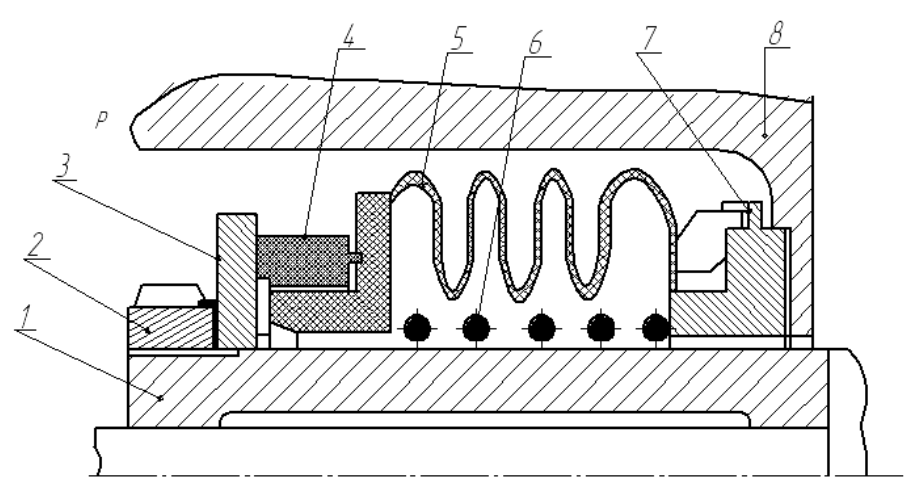

Fig. 1.8. Mechanical seal for aggressive environment

1 -sleeve; 2 - nut; 3 - support sealing ring; 4 -thrust sealing ring;

5 - bellows 6 - a spring in a plastic sheath; 7 - support sleeve; 8 -case 
The presence of abrasive impurities (sand, soil, etc.) in the sealing fluid causes increased wear of the sealing parts, especially the elements of friction pairs.

The mechanical seal for the abrasive or fibrous medium (Fig. 1.9) differs by the presence of rubber bellows 7, 10, 12, which protect all moving parts from contact with the sealing medium.

If some leakage of the sealing fluid is allowed through the contact area of the sealing rings, it is advisable to use it to create an oil film in the friction pair. The mode of liquid friction thus provided minimizes the coefficient of friction in the vapor 9 (which in this case practically does not depend on the materials of the rings), heat dissipation and wear of the rings. Oil film can form any clean liquid. Sealing, in the friction pair of which the oil film is formed due to the shape of the elements of the pair and the frequency of relative rotation, are called hydrodynamic. Sealing in a friction pair of which the oil film is formed at the expense of the fluid subjected to pressure in the contact area is called hydrostatic.

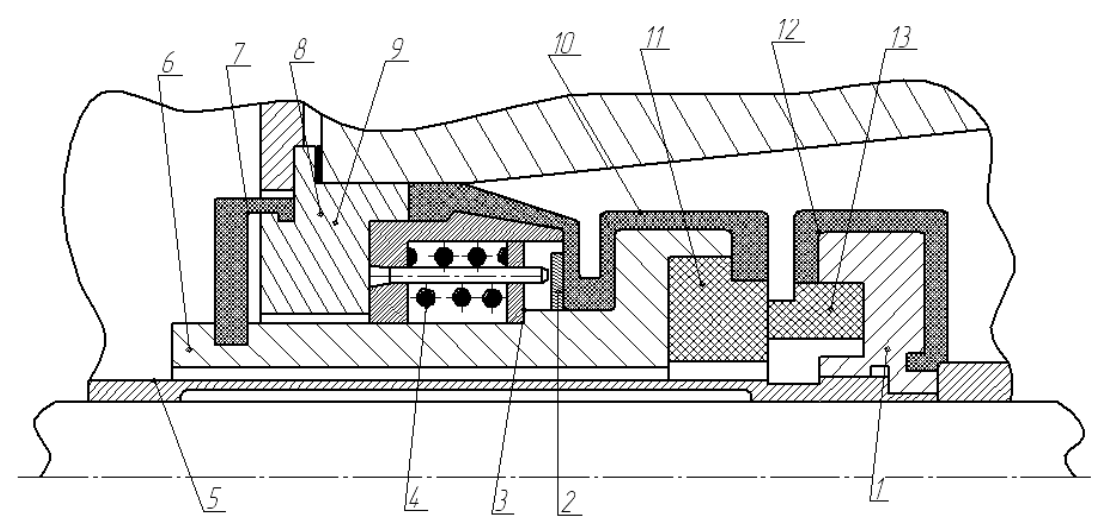

Fig. 1.9. Mechanical seal for abrasive conditions

1 - a ring of support ring; 2, 3 -washers; 4 - a set of springs; 5 - sleeve;

6 - a ring of support ring; 7, 10, 12 - rubber bellows; 9 - a glass;

11 - thrust sealing ring; 13 - support sealing ring

Hydrodynamic and hydrostatic seals have the greatest durability and are used at high sliding speeds. The gap in the friction pair is, as a rule, 2-20 microns. The hydrodynamic effect in the designs of the end seals is provided by the rolling on one of the rings. The variants of hydrodynamic friction pairs are shown in fig. 1.10.

Hydrostatic mechanical seal, depicted in fig. 1.11 includes a shaft bunch 1 (bearing seal ring) and a thrust sealing ring 3 pressed by a set of springs 5 and mounted in the housing on rubber rings 4 and 6 . In ring 3 , a circular groove is provided that connects with the cavity through several 
holes in case 2 , the cavity is filled with a pressure fluid that exceeds the pressure of the sealing medium, through the hole in the body ${ }^{8}$.

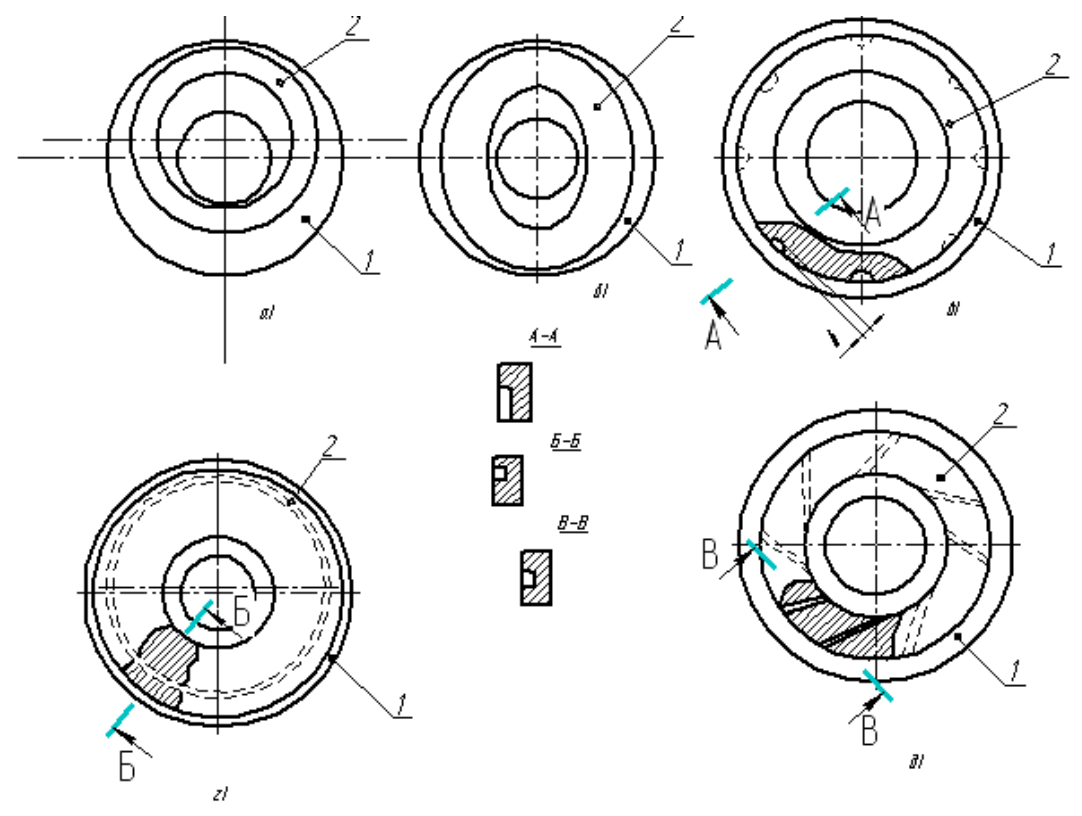

Fig. 1.10. Rings of a hydrodynamic friction pair

$a$-eccentric placement of rings; $b$ - the oval form of one of the rings;

$c$-with a groove on the periphery of one of the rings; $d$-circular flow

through one of the rings; $e$ - spiral-like risks; 1,2-sealing rings

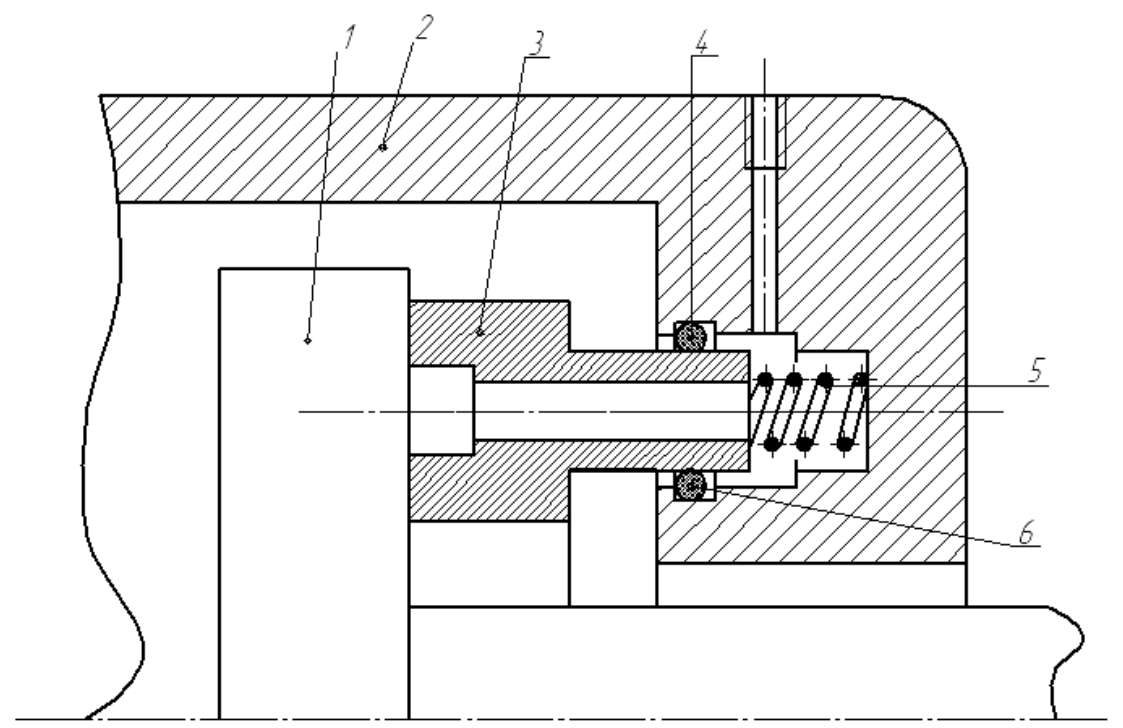

Fig. 1.11. Hydrostatic sealing

1 - support sealing ring; 2 - body; 3 - ring; 4, 6-the condition of the rings; $5-a$ set of springs

${ }^{8}$ Макаров Г.В. Уплотнительные устройства: справочник. Москва : Машиностроение, 1973. $232 \mathrm{c}$. 
For various designs of the mechanical seals, which are considered, in particular $^{9}$, the same requirements apply, the main of which are: 1) the maximum possible leakproofness; 2) the maximum possible durability (low wear of rings); 3) no need for frequent maintenance; 4) the minimum coefficient of friction and, accordingly, heat dissipation; 5) low cost.

In most cases, the ring seals fail due to the following reasons:

a) high local temperature, which occurs on the surface of the slip of the seal and causes jamming of the materials of the friction pairs;

b) insufficient quality of rubbing, as a result of which pressure of the leaks increases;

c) insufficient strength of the sealing material, for example, ceramics, fluoroplasts;

d) cracking of metal ceramic fastened on a metal base due to thermal stresses;

e) fluid leakage through the pores of the sealing material with increasing pressure, for example, for materials: iron graphite, carbon graphite, and others. without leakage.

The wear of sealing rings in mobile joints can be divided into 5 groups:

1) adhesive as a result of the forces attracting the surface of the friction;

2) abrasive, resulting from the adhesion of the roughness of the two roughly treated surfaces or when it enters the gap of the abrasive particles, with abrasive wear a few tens of times higher than the adhesive;

3) corrosive, which is promoted by chemical reactions, in particular high temperatures in the sealing gap;

4) superficial, caused by formation in contacting surfaces of cracks that arise under the influence of thermal stresses and fatigue;

5) erosion, which occurs as a result of erosion of liquids and gases at high flow rates.

During operation, there can be one type of wear and a combination of them.

Most of mechanical seals work in rather favorable friction modes from the semi-liquid to the liquid, but along with this are quite common cases when the steam operates in the modes from boundary to dry friction. Dryfriction modes in pump shaft seals are observed, for example, in the operation of pumps that are not flooded, at the initial start-up, in case of

9 Воронков Б.Д. Подшипники сухого трения: монография. Ленинград : Машиностроение. Ленингр. отд., 1979. 224 с. 
fluid supply failures, etc. This leads to a significant temperature gradient and, consequently, the emergence of thermal stresses followed by thermal cracking of the working surfaces of the rings. Tests and operation of the mechanical seals have shown that thermal cracking of rings of friction pairs is observed quite often. In some cases, after the detection of crack cracks, the seals continue to work with increased fluid flow and increased wear before the next trickle of friction pairs, which is accompanied by an increase in non-flatness and a decrease in the purity of the surface of the friction (Fig. 1.12).

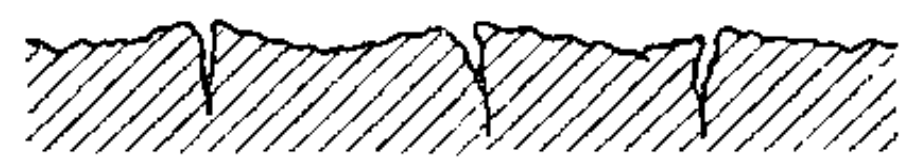

\section{Fig. 1.12. Profile of the surface of the ring with thermal cracks}

In other cases, the seal after the thermal cracking fails due to the unacceptably high fluid flow due to partial or complete destruction of the rings of the friction pair. As a rule, thermal cracking of rings of a friction pair is not accompanied by their destruction and is observed in rings of elastic-plastic materials, for example, from various metals and alloys (carbon, chromium steel, stellites, etc.) with hardness of HRC 40-60. When thermosetting, the temperature on their surfaces reaches $\sim 400{ }^{\circ} \mathrm{C}$ (Fig. 1.13). Cracks are radial and not deep enough to cause a brittle rupture.

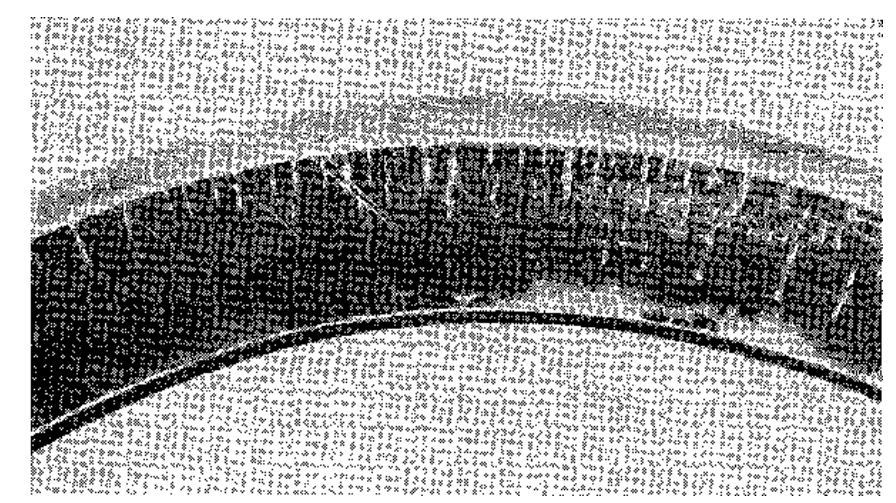

Fig. 1.13. The surface of a metal ring with thermal cracks

The most dangerous are the thermal cracking of rings from brittle materials, whose coefficient of linear expansion is much lower than in steels such as ceramics, in which cross-cracks are formed (Fig. 1.14). 


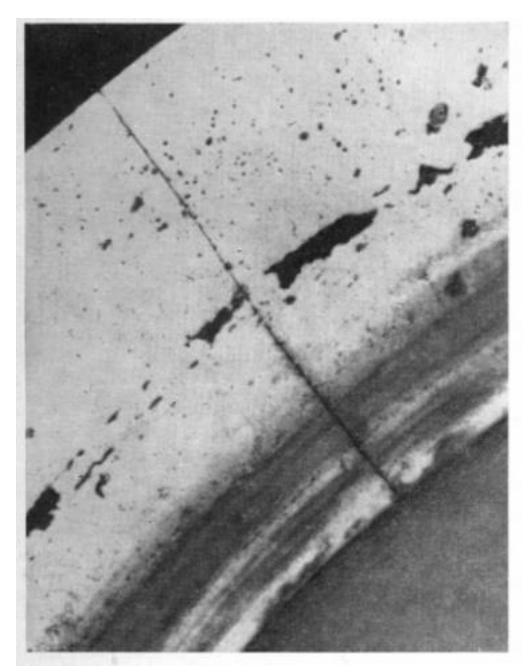

Fig. 1.14. Surface ceramic rings with thermal cracking

\subsection{Materials for mechanical seals}

The key to determining the reliability and durability of mechanical seals is the right choice of materials for sealing rings ${ }^{10}$. The materials of the rings must meet a number of requirements, the main of which according to ${ }^{11}$ are: low friction coefficient and wear intensity in various environments, high corrosion resistance, high thermal conductivity, spin ability, sufficient mechanical strength and performance at elevated temperatures. The most common combination of materials for rings is the use of "soft" material for a stationary and "solid" material for a fixed ring. As "soft" materials are widely used graphite materials, but in some cases, they do not provide sufficient reliability due to their low mechanical strength, therefore, special fillers based on thermoplastic and thermosetting resins are used for their manufacture, which significantly reduce the thermal conductivity of the material $^{12}$. Among the metal binders the highest working characteristics (high strength and thermal conductivity) of graphite materials provide the use of antimony. Such materials are characterized by high resistance to

${ }^{10}$ Huebner M.B. Material selection for mechanical seals : Proceedings of the 21st International Pump User's Symposium (Houston, Texas, February-March 2005). Houston, 2005. PP. 127-135.

11 Федорченко И.М., Пугина Л.И. Композиционные спеченные антифрикционные материалы: монография. Киев: Наук. думка, 1980. 404 с.

${ }^{12}$ Déprez P., Hivart P., Coutouly J. F., Debarre E. Friction and wear studies using Taguchi method: application to the characterization of carbon-silicon carbide tribological couples of automotive water pump seals. Advances in Materials Science and Engineering. London, 2009. № 830476. P. 10. 
blowing and bundle ${ }^{13}$, which occurs when pumping highly viscous liquids and hydrocarbons. However, the widespread use of graphite materials impregnated with antimony is limited for economic reasons, so they are used in special purpose pumps.

The main types of materials for the production of moving rings ${ }^{14}$ are: metallic alloys, structural ceramics, cermets and metal-ceramic composites.

\subsubsection{Metal alloys}

The most common metal alloys for the manufacture of rings are:

- Gray modified cast iron of the brand Meehanite ${ }^{15}$ and modified cast iron with $\mathrm{Ni}, \mathrm{Cu}$ and $\mathrm{Cr}$ grades of the Ni-resist ${ }^{16}$;

- Copper-based alloys: aluminum bronzes and copper-nickel alloys $^{17}$;

- Corrosion-resistant high-chromium steel grades 95Kh18GOST5632-72 ${ }^{18}$ and AISI316;

- Cr-W-Co (stellites) alloys.

The essential advantage of using rings of mechanical seals from metal alloys, primarily from cast iron, bronze and metal, is that when the liquid film disappears in the friction zone and the transition to a dry friction mode, there is no observed failure (the wear process is progressing gradually). In addition, sealing metal rings are characterized by high thermal conductivity (except for stainless steel) and high strength, with their cost is relatively low. Their main disadvantage is low resistance in media containing abrasive particles, so its using is limited to groups I-II (Table 1.1).

${ }^{13}$ Wakely K. Mechanical seals: some developments in face materials. Tribology Int. Amsterdam, 1986. vol.19, №4. PP. 198-203.

14 Müller H.K., Nau B.S. Fluid Sealing Technology: Principles and Applications.monography : NewYork : Marcel Dekker, Inc., 1998. 485 p.

${ }^{15}$ Meehanite worldwide specification handbook. URL: http:// www.meehanite.com/Meehanite_Worldwide_Specification_Handbook_ver09.07.201 3.pdf (дата звернення: 15.12.2018).

16 Криль Я.А., Флюнт О.Р., Криль Г.В. Матеріалознавство. Тлумачний словник: Т.1. Львів : «Новий світ - 2000», 2012. 476 с.

17 Lai T., Gabriel R., Mayer-Yep L. Improved performance seals for pipeline applications. Lubrication Engineering. Amsterdam, 2003. vol.59, №4. PP. 18-29.

18 ОСТ 26-06-1426-87: Уплотнения валов насосов. Классификация и условные обозначения. URL: http://www.complexdoc.ru/ntdpdf/481379/ uplotneniya_valov_nasosov_klassifikatsiya_i_uslovnye_oboznacheniya.pdf (дата звернення: 15.12.2018). 


\subsubsection{Ceramic materials}

Ceramic rings ${ }^{19}$ made of materials based on silicon carbide $(\mathrm{SiC})$ and aluminum oxide $\left(\mathrm{Al}_{2} \mathrm{O}_{3}\right)$ sealing seals are currently the most widespread because of their high wear resistance and chemical inertia in many aggressive environments. Rings from materials based on silicon carbide are most versatile in view of their high wear resistance in conditions of simultaneously abrasive wear and effect of chemically active substances (acids, alkalis, etc.). They are made of:

- reactive-sintered $\mathrm{SiC}$, which is obtained by silicon impregnation of the formed billet from a mixture of graphite and $\mathrm{SiC}$, as a result of the chemical reaction, an additional (secondary) $\mathrm{SiC}$ is formed which binds the grains of the primary $\mathrm{SiC}$ to the continuous frame ${ }^{20}$. While the reaction sintering process is characterized by a slight shrinkage $(<1 \%)$. The structure of the material obtained is characterized by the presence in the intergranular space of free silicon in the amount of $8-12 \%$ (Fig. 1.15, a). The presence of free silicon has a significant effect on the chemical properties of the material, since when passing the reaction of free silicon with the medium that is pumped through the through channels formed filled with reaction products and the friction pair fails. In order to increase the content of the carbide phase and, consequently, to reduce the proportion of free silicon into the composition of the initial composition, $\mathrm{SiC}$ particles are introduced which differ significantly in size (Fig. 1.15, b).

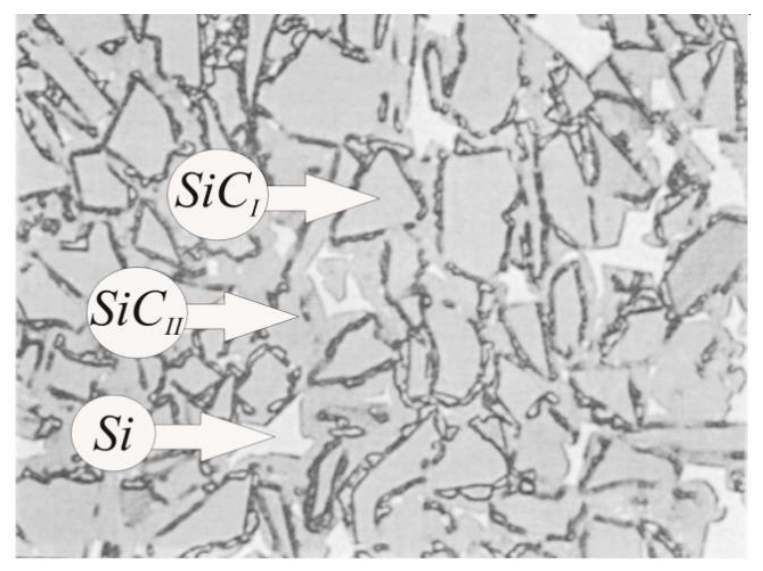

a

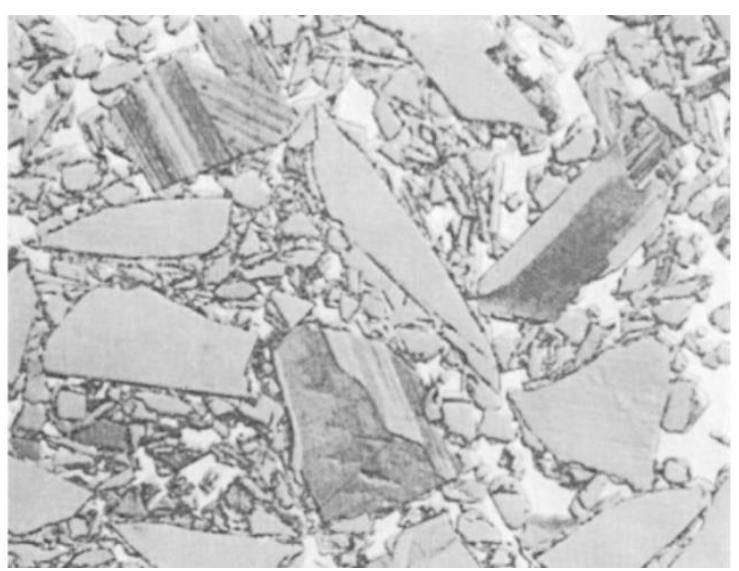

b

Fig. 1.15. Structure of silicon carbide:

$a$ - reactionary sintered; $b$ - of bimodal

19 Самсонов Г.В., Винницкий И.М. Тугоплавкие соединения: справочник. Москва : Металлургия, 1976. 560 с.

${ }^{20}$ Гнесин Г.Г. Бескислородные керамические материалы: монография. Київ : Техніка, 1987. 152 с. 
- $\mathrm{SiC}$ in the solid phase are obtained by sintering at temperatures of $2000-2100{ }^{\circ} \mathrm{C}$ from preforms made of submicron powders with high superficial surface energy and a specific surface $\sim 45 \mathrm{~m}^{2} / \mathrm{g}$, which makes it possible to obtain shrinkage when sintered to $23 \%^{21}$ (Fig. 1.16). To accelerate the shrinkage process,

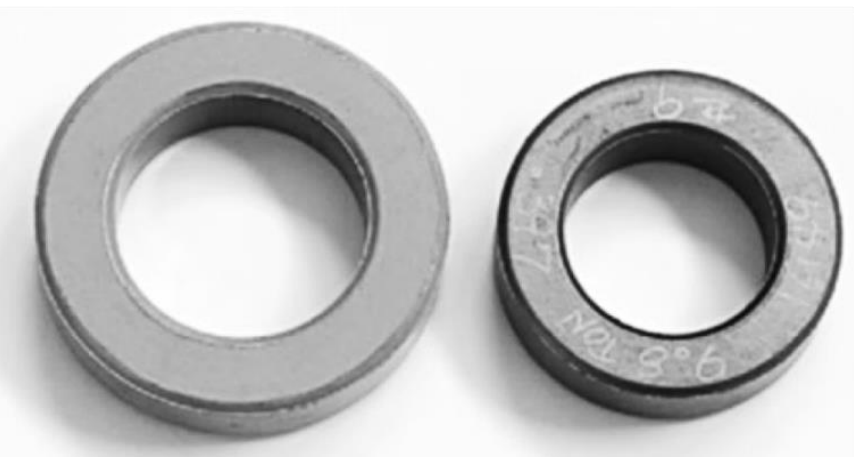

Fig. 1.16. SiC shrinkage after solid-phase sintering activating additives of carbon, boron and aluminum are often used in an amount of $\sim 1$ wt. \%

- Sliced graphite is obtained by the method of reaction impregnation of porous graphite billets with silicon in a protective atmosphere at temperatures $\sim 2000{ }^{\circ} \mathrm{C}$. The structure of the material obtained is a continuous $\mathrm{SiC}$ frame containing carbon and graphite inclusions. Such structure (Fig. 1.17) provides simultaneous high antifriction properties and high thermal conductivity. For the manufacture of rings of mechanical seals, siliconized graphite of the SG-T grades (obtained by infiltration with graphite silicon of the mark PG-50), SG-P (obtained by impregnation with silicon of graphite chips, crushed graphite waste preplasticized and formed with the use of pulverbakelite) are used.

Graphite infiltration with Si-B alloys is borosilated graphite (BSG-60), which, in comparison with siliconized graphite, is characterized by low residual porosity, high compressive strength and hardness, as well as chemical resistance, in particular, in solutions of sulfuric nitric, hydrochloric and phosphoric

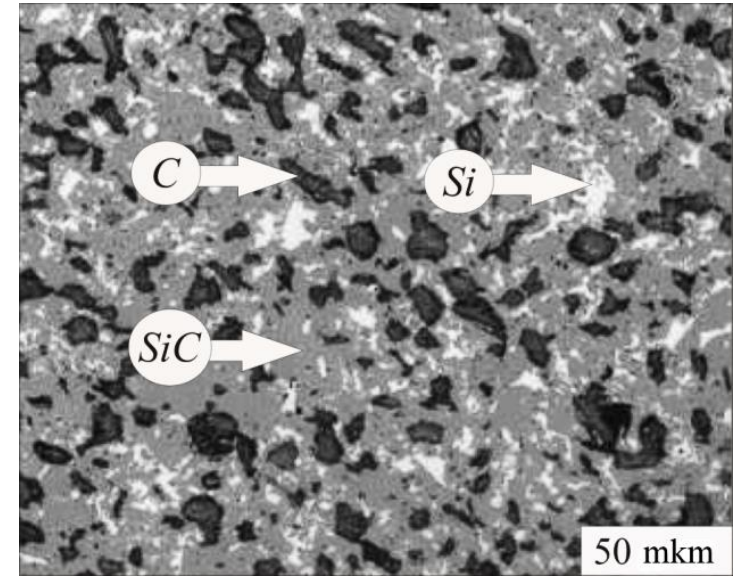

Fig. 1.17. Structure of Sliced Graphite ${ }^{22}$

${ }^{21}$ Неметаллические тугоплавкие соединения : монография / Т.Я. Косолапова и др. Москва : Металлургия, 1985. 224 с.

22 Сорокин О.Ю., Бубненков И.А., Кошелев Ю.И. и др. Разработка мелкозернистого силицированного графита с улучшенными свойствами. Химия и химическая технология. Иваново, 2012. Т. 55, № 6. С. 12-16. 
acids. The most universal mark of siliconized carbides is the doped material additionally of aluminum oxide (grade HACC 55/40), which is characterized by high chemical resistance in a number of aggressive acidic media ${ }^{23}$. In order to increase the operational characteristics of siliconized graphite, in particular, the fracture strength of the formation of blanks is carried out by vacuum pressing ${ }^{24}$. The common disadvantage of siliconized graphite is the high brittleness, low tensile strength, which makes it difficult to fix them in metal cases.

Rings from materials based on aluminum oxide are obtained by forming billets of a given shape by pressing or molding under the pressure of a plasticized mass from alumina powders $\left(\mathrm{Al}_{2} \mathrm{O}_{3}\right)$, a purity of $94-99 \%$, and subsequent sintering in the air, which is accompanied by a significant shrinkage (Fig. 1.9). The obtained rings are characterized by high hardness and extremely high chemical resistance in the vast majority of acids, alkalis and hydrocarbons (up to $1800^{\circ} \mathrm{C}$ ) ${ }^{25}$ which allows them to be

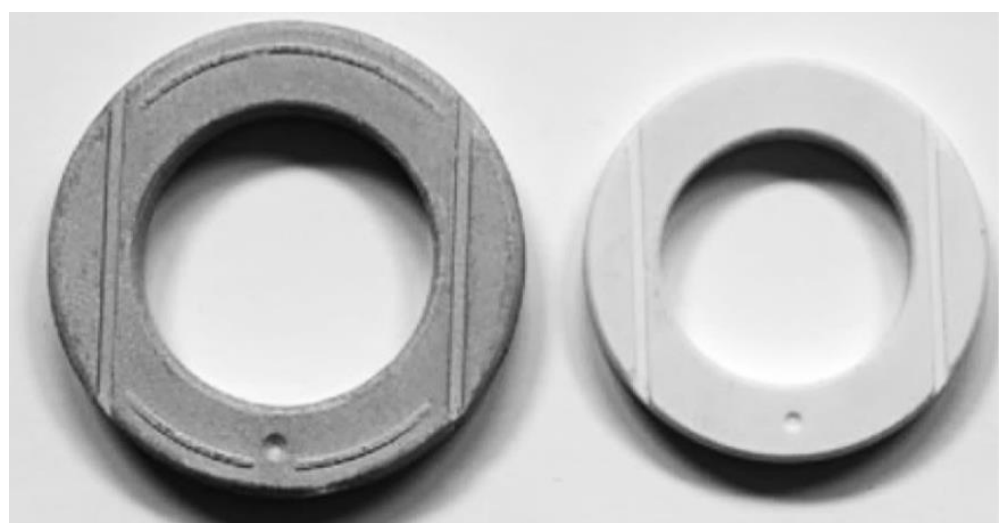

Fig. 1.18. Nature of shrinkage of $\mathrm{Al}_{2} \mathrm{O}_{3}$ after solid-phase sintering used in pumps for the petrochemical industry, but the main factor inhibiting their widespread use there is a low resistance to heat shocks that arise when switching to dry friction $\operatorname{mode}^{26}$.

The authors ${ }^{27}$ are recommended to improve the performance of

23 Материалы уплотняющих колец торцового уплотнения. URL: http://www.sealtd.com.ua/tor/ring_matirial.html (дата звернення: 15.12.2018).

24 Гнилиця І.Д., Криль Я.А., Цап. І.В. Дослідження впливу технологічних параметрів процесу одержання силіційованих графітів для виготовлення кілець торцьових ущільнень відцентрових насосів на їх експлуатаційні властивості. Проблеми трибології. Хмельницький, 2011. № 3. С. 39-43.

25 Борисова А.Л. Физико-химические свойства окислов: справочник. Москва : Металлургия, 1978. 472 с.

${ }^{26}$ Flitney R.K. Seals and sealing handbook, sixth edition. monography: Oxford: Butterworth-Heinemann, 2014. $648 \mathrm{p}$

27 Bellosi A., Daurelio G., Chita G. UV laser ablation of alumina ring faces for mechanical seal applications. Applied Physics A. Berlin: Springer Berlin Heidelberg, 1999. vol.69, № 1. PP. 539-542. 
sealing rings to modify the surface layer to a depth of $\sim 2 \mu \mathrm{m}$ by laser intensification with a low intensity of irradiation $\left(1.8 \mathrm{~J} / \mathrm{cm}^{2}\right)$, which allows the grain size to be significantly reduced, micropores can be created and roughness reduced.

In order to combine the properties of $\mathrm{SiC}$ and $\mathrm{Al}_{2} \mathrm{O}_{3}$ for the manufacture of rings of seal seals developed composites of the brand $\mathrm{SIAL}^{28}$, which are obtained by hot pressing without a protective atmosphere at temperatures $1600-2250{ }^{\circ} \mathrm{C}$ pre-dispersed $4-6$ microns mixture of $\mathrm{SiC}$ and $\mathrm{Al}_{2} \mathrm{O}_{3}$ powders. The results of testing these materials during sliding friction show that in the system $\mathrm{SiC}-\mathrm{Al}_{2} \mathrm{O}_{3}$ the highest complex of tribology characteristics is achieved with an equal component of the components in the initial composition (material SiAl-50).

Silicon nitride $\left(\mathrm{Si}_{3} \mathrm{~N}_{4}\right)$ obtained by hot pressing or high-temperature gas-static sealing $^{29}$ is used mainly for rings of special mechanical seals, which are subject to high requirements for cracking and strength at high slip rates and temperatures. For rings from $\mathrm{Si}_{3} \mathrm{~N}_{4}$-based materials that work under particularly difficult conditions (Group IV, Table 1), the authors of the paper ${ }^{30}$ propose to apply on the working surfaces diamondlike coatings (DLCs) that provide high wear resistance due to low friction coefficient $\sim 0.001$ (in a water environment) caused by passing of processes of self-lubrication in the zone of frictional contact.

\subsubsection{Cermets and metal-ceramic composites}

The most widely used cermets for the production of sealing rings since the 1960s are tungsten solid alloys of WC-Co and WC-Ni systems obtained by rare-phase sintering, the amount of metal bonds in which is 6-15 wt. \% Their use as tribotechnical materials is due to the high modulus of elasticity of the carbide phase, hardness and toughness during bending and compression (the highest among all known cermets), high thermal conductivity (depending on the content of the metal component). Tungsten cemented carbides can be used rationally in pairs where there

28 Уманский А.П., Довгаль А.Г., Костенко А. Д. Влияние состава и структуры карбидокремниевых композитов на износостойкость и механизмы их изнашивания при трении в паре с керамическим контртелом. Проблеми трибологї̈. Хмельницький, 2011. №3. С. 81-88.

29 Крыль Я.А. Высокотемпературное газостатическое уплотнение нитрида кремния: монография. Киев : Наукова думка, 1993. 141 с.

30 Vila M., Carrapichano J.M., Gomes J.R. Ultra-high performance of DLCcoated Si3N4 rings for mechanical seals. Wear. Amsterdam, 2008. vol.256, № 5-6. PP. 940-944. 
are significant specific loads (III-IV group, Table 1) and the presence of abrasive particles is assumed. Despite its versatility, the sealing rings of tungsten solid alloys of the WC-Co system have a number of disadvantages due to the low chemical resistance of cobalt, which dissolves even in chemically pure water, high material density, which complicates the operation of high-speed friction pairs, as well as high cost. In addition to tungsten cemented carbides, metal-ceramic composites (sometimes with graphite additives) are also used on the basis of refractory compounds of the IV-VI periodic system of elements such as $\mathrm{TiC}, \mathrm{Cr}_{3} \mathrm{C}_{2}, \mathrm{VC}, \mathrm{NbC}, \mathrm{TaC}$ and their combinations, the role of a metal component in such materials is alloyed alloys based on $\mathrm{Ni}, \mathrm{Cu}$ et $\mathrm{al}^{31}$.

Table 1.2

\section{Comparative characteristic of the properties of the main types} of materials for the manufacture of rings of mechanical seals ${ }^{32}$

\begin{tabular}{|c|c|c|c|c|c|c|}
\hline Material & 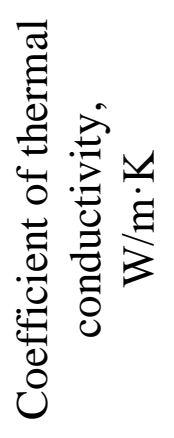 & 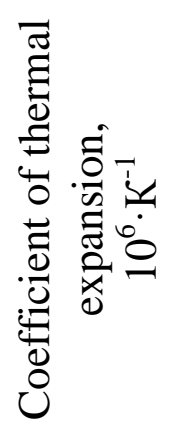 & 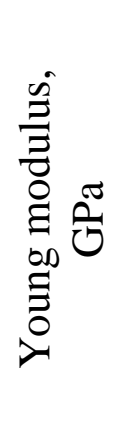 & 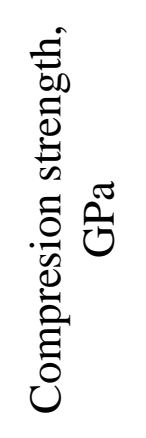 & 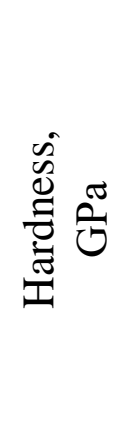 & 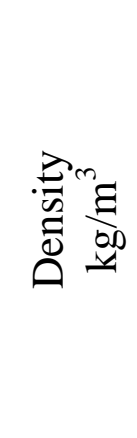 \\
\hline Graphite $+S b$ & 20 & 3,5 & 33 & 280 & - & 2300 \\
\hline Aluminum bronze & 42 & 18 & 130 & 960 & - & 7600 \\
\hline $\begin{array}{l}\text { Gray iron } \\
\text { (Meehanite) }\end{array}$ & 42 & 10 & 110 & 720 & - & 7200 \\
\hline Niresist & 40 & 19 & 96 & - & 150 & 7300 \\
\hline Stainless steel (316) & 16 & 16 & 190 & - & 185 & 8100 \\
\hline \begin{tabular}{|l|} 
Stellite \\
\end{tabular} & 15 & 11 & 250 & - & 600 & 8700 \\
\hline $\mathrm{Al}_{2} \mathrm{O}_{3},(95 \%)$ & 30 & 6,9 & 365 & 3200 & 1500 & 3900 \\
\hline reactionary $\mathrm{SiC}$ & 150 & 4,3 & 410 & - & 3000 & 3100 \\
\hline$S i C$ sintered & 100 & 4,8 & 390 & 10000 & 2800 & 3100 \\
\hline$W C+C o$ & 105 & 4,5 & 650 & 6900 & 1300 & 15000 \\
\hline
\end{tabular}

31 Бондаренко В.П. Триботехнические композиты с высокомодульными наполнителями : монография. Киев : Наукова думка, 1987. 232 с.

${ }^{32}$ Nau B.S. Mechanical seal face materials: Proceedings of the Institution of Mechanical Engineers, Part J : Journal of Engineering Tribology (London, March 1). London, 1997. PP. 165-183. 
In the works ${ }^{33,34,35}$ different methods for obtaining mechanical seals are proposed. Which consist of filling the ring groove of steel billet with solid alloy granules and subsequent sintering at temperatures of $1150-1200{ }^{\circ} \mathrm{C}$ during which the groove is infiltrated by copper-nickel alloy $(\mathrm{Cu}+10 \%$ by weight $\mathrm{Ni})$ of which is $60 \mathrm{wt}$. \% of the amount of carbide mixture.

\subsection{Combination of materials in friction pairs}

Along with the choice of materials for friction pairs, it is extremely important to combine them in different combinations to avoid stacking, scratching and cracks, and also ensure the existence of a lubricant film in the friction zone, since the transition from liquid to dry friction results in an increase in the coefficient of friction in practically 30 times $^{36}$. According to the international ISO standard ${ }^{37}$, friction pairs are the most successful combination of heterogeneous materials, for example: graphite based material - silicon carbide. However, in cases where the friction pair operation is accompanied by factors such as the presence of abrasive particles in the medium, the high viscosity of the medium and the possibility of its crystallization or polymerization, the presence of strokes and vibrations, combinations of two solid materials such as $\mathrm{SiC}-\mathrm{SiC}$, $\mathrm{WC}+\mathrm{Co}(\mathrm{Ni})-\mathrm{WC}+\mathrm{Co}(\mathrm{Ni}), \mathrm{SiC}-\mathrm{WC}+\mathrm{Co}(\mathrm{Ni})$. As can be seen from the comparative characteristics (Table 1.2), the highest complex of performance characteristics is characterized by a pair of silicon carbide per silicon carbide. This is also confirmed by the experience of one of the world's leading manufacturers of pumping equipment by Grundfos ${ }^{38}$. The level of operational properties of silicon carbide materials can be

33 Способ изготовления контактных поверхностей торцевых пар трения: Пат. 2169640 РФ. МПКВ22F7/04. №2000118575/02; заявл. 17.07.2000; опубл. 27.06.2001.

${ }^{34}$ Composite wear-resistant articles such as face seals: Пат. US3594011 A USA, МПКВ22F7/08; заявл. 04.08.1968; опублік. 20.07.1971.

35 Method of making composite wear resistant articles, such as face seals: Пат. US3666456 A USA, МПКВ22F7/08; заявл. 14.09.1970; опублік. 30.05.1972.

36 Wei L., Gu B. Q., Feng X., Sun J. J. Research on friction characteristic of end faces of mechanical seals. Advanced Tribology: Proceedings of CIST2008 \& ITS-IFToMM2008. London, 2010. PP. 304-308.

${ }^{37}$ ISO 21049/API 682, 2004, Pumps - shaft sealing systems for centrifugal and rotary pumps. URL: https://www.iso.org/standard/35625.html (дата звернення: 15.12.2018).

38 Chapter 3 Materials. URL: http://machining.grundfos.com/media/16605/ shaftseal_chapter3.pdf (дата звернення: 15.12.2018). 
improved by adding molybdenum $\mathrm{Mo}_{5} \mathrm{Si}_{3}$ and $\mathrm{MoSi}_{2}{ }^{39}$, as well as active metals (Al, Ti, Cr) and boron ${ }^{40}$, which partially eliminates free silicon in the material structure. In materials based on $\mathrm{SiC}$ obtained by hot pressing with the addition of $\mathrm{MoSi}_{2}$, the crack strength increases by almost $50 \%{ }^{41}$. In such pairs, a sufficient number of lubricating liquids in the contact area is a prerequisite for their satisfactory operation, otherwise an intensive destruction of the sealing elements takes place (Fig. 1.19).

For light working conditions (sliding speed of $5 \mathrm{~m} / \mathrm{s}$, pressure up to $0.5 \mathrm{MPa}$ ), infiltrated graphite is used most often in pairs with a rotary ring made of metal alloys, for example with gray iron when pumping oil, aluminum bronze when working in a medium of water and iron, grade $\mathrm{Ni}$ resist, stainless steel or stellite in poorly aggressive environments.

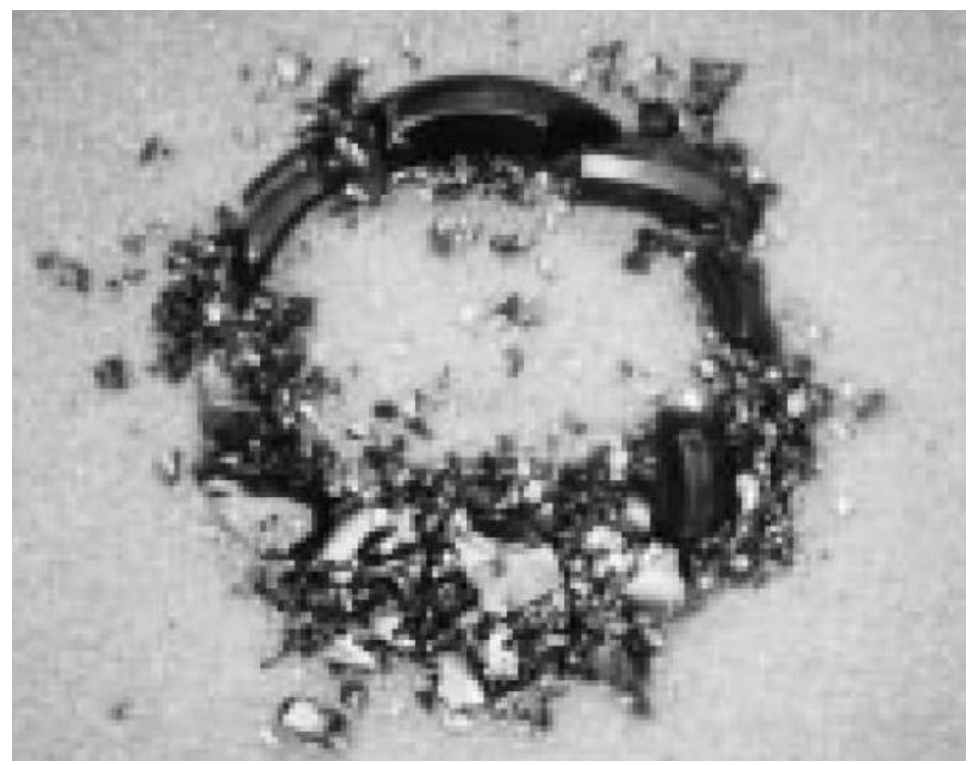

Fig. 1.19. The nature of the destruction of the $\mathrm{SiC}$ ring, with the appearance of dry friction due to the evaporation of the liquid film after friction by the counter body of a tungsten cemented carbide

39 Гнесин Б.А. Возможности управления связностью карбида кремния в композиционных материалах карбид кремния силициды молибдена. Наука $u$ Образование. МГТУ им. Н.Э. Баумана. Электрон. журн. Москва, 2014. № 12. С. 941-950.

${ }^{40}$ Mayer S., Heinrich Ju.G Processing-microstructure properties relationships of MoSi2-SiC composites. Journal of the European Ceramic Society. Amsterdam, 2002. vol.22, №13. PP 2357-2363.

${ }^{41}$ Suresh Kumar R., Sivakumar D., Venkateswarlu K., Gandhi A.S. Mechanical behavior of molybdenum disilicide reinforced silicon carbide composites. Scripta Materialia. Amsterdam, 2011. Vol. 22, №13. PP. 838-841. 
Comparative characteristic of combinations of friction pairs of mechanical seals

\begin{tabular}{|l|l|c|c|}
\hline \multicolumn{2}{|c|}{ Friction pair } & $\begin{array}{c}\mathrm{pv}, \\
\mathrm{MPa} \cdot \mathrm{m} / \mathrm{s}\end{array}$ & $\begin{array}{c}\text { Friction } \\
\text { coefficient }\end{array}$ \\
\hline \multirow{4}{*}{ Carbographite } & Ni-resist & 3,5 & 0,07 \\
\cline { 2 - 4 } & Aluminum oxide & 3,5 & 0,07 \\
\cline { 2 - 4 } & $\mathrm{WC}+\mathrm{Co}(\mathrm{Ni})$ & 17,5 & 0,07 \\
\cline { 2 - 4 } & $\mathrm{SiC}$ & 17,5 & 0,02 \\
\hline $\mathrm{WC}+\mathrm{Co}(\mathrm{Ni})$ & $\mathrm{WC}+\mathrm{Co}(\mathrm{Ni})$ & 4,2 & - \\
\hline $\mathrm{SiC}$ & $\mathrm{SiC}$ & 17,5 & $0,02-0,05$ \\
\hline
\end{tabular}

\subsection{Perspectives for the use of dispersion-aging copper-nickel-manganese alloys as components for the manufacture of rings of mechanical seals}

\subsubsection{Properties of copper-nickel-manganese alloys}

Alloys based on copper, which have the ability to strengthen during aging, are promising for use as a matrix phase in cermets for tribotechnical purposes. Their use allows you to adjust the hardness and viscosity of cermets in a fairly wide range. This creates conditions for facilitating the machining of non-heat-treated "soft" billets from cermets and subsequent rendering of the necessary hardness by strengthening the matrix phase by heat treatment (with aging and subsequent aging).

Representatives of dispersion-hardening alloys on a copper base are, in particular, alloys of the $\mathrm{Cu}-\mathrm{Ni}-\mathrm{Mn}$ system. According to ${ }^{42,43,44,45}$, the highest ability to strengthen during heat treatment is observed for alloys with $\mathrm{Cu}$ content of 60 wt. \% (the remaining $\mathrm{Ni}$ and $\mathrm{Mn}$ in the same proportions), in addition the mentioned alloys are characterized by high corrosion resistance.

${ }^{42}$ Dean R. S., Anderson C.T. Alloys of manganese-copper and nickel. Am. Soc. Metals Trans. USA, 1941. Vol. 29. PP. 808-812

${ }^{43}$ Belousov V. Ya. Increasing the wear resistance of granular tungsten carbide base composite materials by heat treatment. Soviet materials science. Lviv, 1979. Vol. 15, № 5. PP. 512-514.

44 Masamichi Miki, Shigenori Hori Grain Boundary Reaction in a Cu-Ni-Mn Alloy. Soviet materials science. Sendai, 1982. Vol. 46, № 3. PP. 301-307

45 Shapiro S., Derek E. Tyler, R. Lanam Phenomenology of precipitation in copper-20 pet nickel-20 pct manganese. Metallurgical Transactions. USA, 1982. Vol. 46, № 3. PP. 301-307 
The earliest phase equilibrium studies in the $\mathrm{Cu}-\mathrm{Ni}-\mathrm{Mn}$ system are presented in ${ }^{46}$, where the surfaces of solidus and liquid chromatographs were determined using thermal analysis for a wide range of concentrations. $\operatorname{In}^{47}$, a ternary system was constructed in which the author of ${ }^{48}$ made changes to the rich manganese corner diagram based on the analysis of isothermal section at $1000^{\circ} \mathrm{C}, 700^{\circ} \mathrm{C}$ and $500{ }^{\circ} \mathrm{C}$, which indicate the existence of solid solutions based on polymorphous manganese modifications. Studies ${ }^{49}$ were carried out in copper-rich charts at 35\% Mn and 35\% Ni by mass by X-ray, thermal and metallographic analysis, and also by measurements of hardness. As a result, an existing $\mathrm{Cu}$-based solid solution $(\mathrm{Cu}, \gamma \mathrm{Mn}, \mathrm{Ni})$ and intermetallic $\mathrm{MnNi}$, which dissolves at an increase in temperature, was confirmed. The concentration region of the existence of alloys, which are strengthened by heat treatment, corresponds to the quasi-binary section of $\mathrm{Cu}-\mathrm{MnNi}$, which can be explained by the results of the study ${ }^{50}$, in which the microhardness of alloys with a $\mathrm{Cu}$ content of $95 \%$ and $90 \%$ was measured. The alloys were annealed at $900{ }^{\circ} \mathrm{C}, 700^{\circ} \mathrm{C}$ and $500{ }^{\circ} \mathrm{C}$. The sharp drop in microhardness at the intersection points of the quasi-binary diagram of $\mathrm{Cu}-\mathrm{MnNi}$ was explained by the dissolution of $\mathrm{MnNi}$ intermetallics. In the paper ${ }^{51}$ phase transformations were studied in the heat treatment of $\mathrm{Cu}-\mathrm{MnNi}$ alloys by $\mathrm{X}$-ray analysis; the decomposition of the solid solution was observed at temperatures around $350-370^{\circ} \mathrm{C}$. This was explained by the formation of low-temperature modification of $\mathrm{MnNi}$, as a result of a decrease in the solubility of $\mathrm{Mn}$ and $\mathrm{Ni}$ in $\mathrm{Cu}$ with a decrease in temperature. Isolation of the intermetallic phase $(\mathrm{MnNi})$ in alloys with a content of $20 \mathrm{wt} \% \% \mathrm{Mn}$ and $\mathrm{Ni}(\mathrm{Cu}$ the rest) leads to a significant (to the level of steels) tensile strength (up to $1550 \mathrm{MPa})^{52}$.

${ }^{46}$ Parravano N. The Ternary Nickel-Manganese-Copper Alloys. Gazz. Chim. Ital. 1912. Vol. 42, № 11. PP. 385-394.

${ }^{47}$ Fischer V. The Equilibrium Diagrams for the Ternary Systems. Z. Metallkd. München, 1934. Vol. 26, № 4. PP. 80-82.

${ }^{48}$ Zwicker U. Structure of Manganese rich Manganese-Copper-Nickel Alloys. Z. Metallkd. München, 1951. Vol. 42. PP. 331-335.

${ }^{49}$ Chjan B.C. The Study of Ternary Copper Alloys of Copper-Nickel-Manganese. Izv. Vyss. Uchebn. Zaved. Tsvetn. Metall., 1951. Vol. 42. PP. 331-335.

50 Glasov V.M. Chemical interaction between nickel and manganese in ternary cooper - based solid solution at various temperatures. Dokl. Acad. Nauk SSSR., 1962. Vol.144, № 3. PP. 565-568.

51 Rolland J., Whitwham D. Decomposition of Pseudobinary Cu-NiMn Alloys. Compt. Rend. Acad. Sci. Paris, 1970. ser. C, 270, № 3. PP. 1777-1780.

52 Осинцев О. Е., Федоров В.Н. Медь и медные сплавы. Отечественные и зарубежное марки: справочник. Москва: Машиностроение, 2004. 336 с. 
According to the results of the analysis of studies conducted from 1912 to 2006 , the authors ${ }^{53}$ in the system of $\mathrm{Cu}-\mathrm{Mn}-\mathrm{Ni}$ showed no ternary compounds, the possible phases in this system are shown in Table 1.4.

The liquidus and solidus lines for the $\mathrm{Cu}-\mathrm{Mn}-\mathrm{Ni}$ system are shown in fig $1.20,1.21$. As it shown in the diagram, there are two solid phases (separated by a dashed line connecting nonvariant transformations in binary systems $(\delta \mathrm{Mn}) \leftrightarrow \mathrm{L}+(\gamma \mathrm{Mn}, \mathrm{Cu})$ and $(\delta \mathrm{Mn})+\mathrm{L} \leftrightarrow(\gamma \mathrm{Mn}, \mathrm{Ni}))$ is a copper-based solution $(\mathrm{Cu}, \gamma \mathrm{Mn}, \mathrm{Ni})$ and $\delta \mathrm{Mn}$.

Table 1.4

Possible phases in the $\mathrm{Cu}-\mathrm{Mn}-\mathrm{Ni}$ system

\begin{tabular}{|c|c|c|}
\hline Phase & $\begin{array}{c}\text { Temperature interval } \\
\text { of existence, }{ }^{\circ} \mathrm{C}\end{array}$ & $\begin{array}{c}\text { Space group, } \\
\text { prototype }\end{array}$ \\
\hline$(\gamma \mathrm{Mn}, \mathrm{Ni}, \mathrm{Cu})$ & $<1455$ & $\begin{array}{c}F m 3 m \\
\mathrm{Cu}\end{array}$ \\
\hline$(\delta \mathrm{Mn})$ & $1246-1138$ & $\begin{array}{c}\mathrm{Im} 3 m \\
\mathrm{~W}\end{array}$ \\
\hline$(\beta \mathrm{Mn})$ & $1100-586$ & $\begin{array}{c}P 4132 \\
\beta \mathrm{Mn}\end{array}$ \\
\hline$(\alpha \mathrm{Mn})$ & $<727$ & $\begin{array}{c}I 3 m \\
\alpha \mathrm{Mn}\end{array}$ \\
\hline$\eta, \mathrm{MnNi}$ & $911-675$ & $c P 2$ \\
\hline$\eta^{\prime}, \mathrm{MnNi}$ & $775-620$ & $P 4 / m m m$ \\
\hline$\eta,, \mathrm{MnNi}$ & $<480$ & $\mathrm{AuCu}$ \\
\hline$\gamma^{\prime}, \mathrm{MnNi}^{\prime}$ & $<520$ & $P m 3 m$ \\
\hline$\varphi, \mathrm{Mn}_{3} \mathrm{Ni}$ & $<430$ & $\mathrm{AuCu} 3$ \\
\hline$\varepsilon, \mathrm{Mn}_{2} \mathrm{Ni}$ & $720-560$ & - \\
\hline$\zeta, \mathrm{MnNi}_{2}$ & $710-580$ & - \\
\hline $\mathrm{Cu}_{3} \mathrm{Mn}$ & $\leq 450$ & - \\
\hline
\end{tabular}

${ }^{53}$ Watson A., Wagner S., Lysova E., Rokhlin L. Cu-Mn-Ni (Copper-ManganeseNickel). Landolt-Börnstein - Group IV Physical Chemistry, 2007. Vol. 11C3. PP. 274-285. 


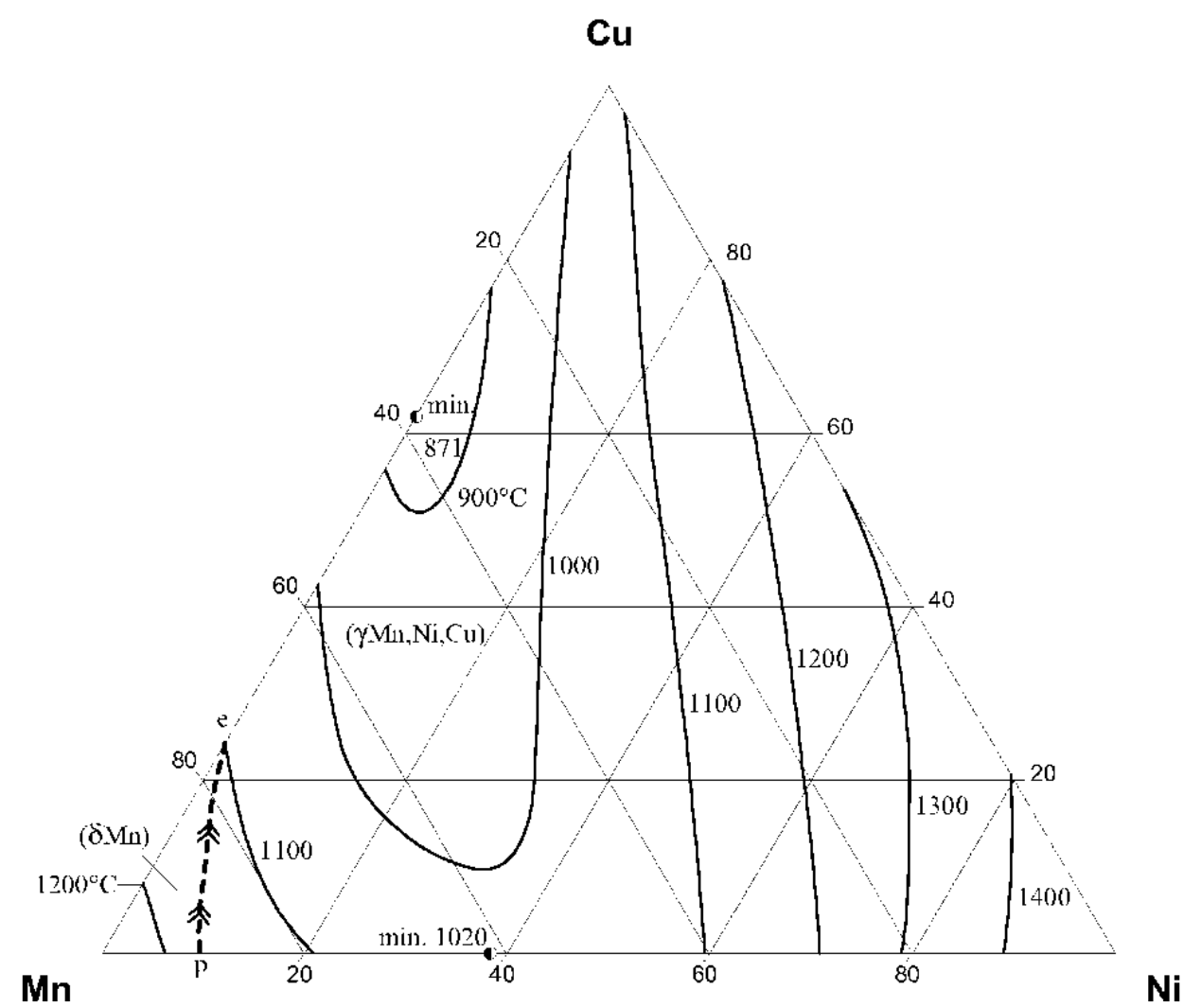

Fig. 1.20. Liquidus projections of the $\mathrm{Cu}-\mathrm{Mn}-\mathrm{Ni}$ diagram

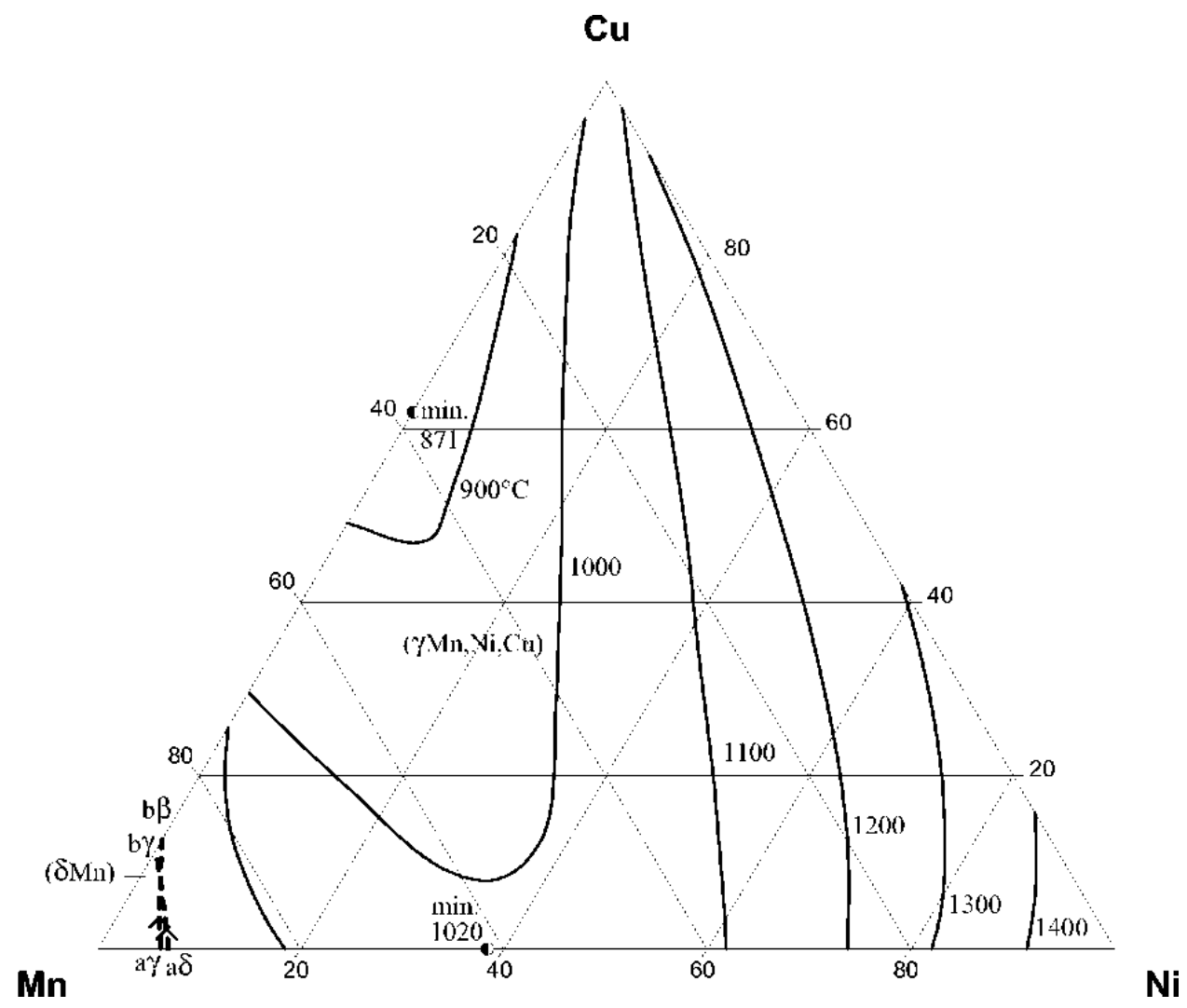

Fig. 1.21. Solidus projections of the $\mathrm{Cu}-\mathrm{Mn}-\mathrm{Ni}$ diagram 
For the study of the aging processes of the $\mathrm{Cu}-\mathrm{Ni}-\mathrm{Mn}$ alloys, it is expedient to consider the $\mathrm{Cu}-\mathrm{NiMn}$ system as a polythermal section of the ternary diagram with equivalent fractions of $\mathrm{Ni}$ and $\mathrm{Mn}$, this diagram is shown in Fig. 1.22.

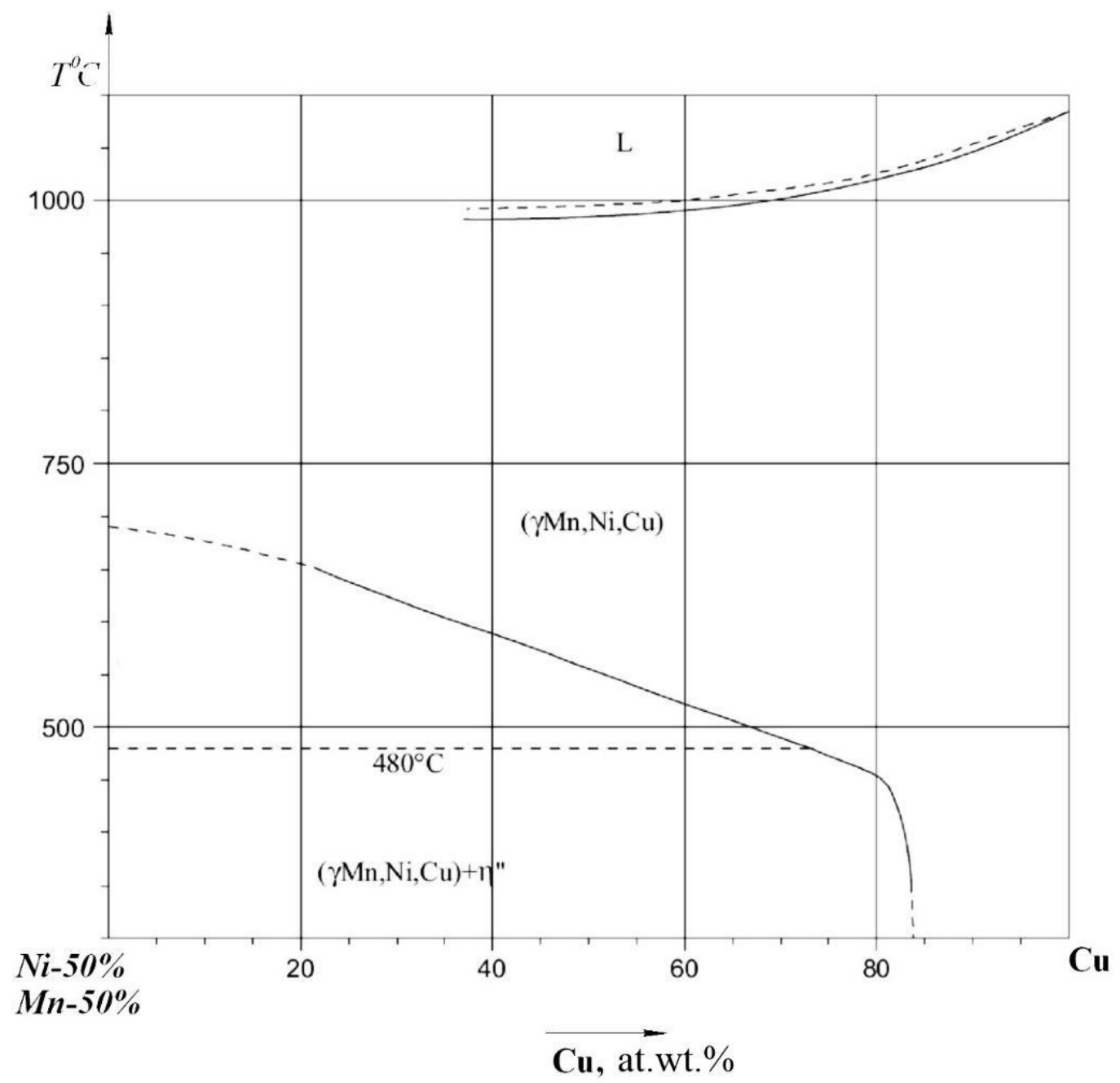

Fig. 1.22. Polythermal separation of the triple system $\mathrm{Cu}-\mathrm{Ni}-\mathrm{Mn}$, with equivalent atomic shares of $\mathrm{Ni}$ and $\mathrm{Mn}$

From the diagram it can be seen that with the increase of the equivalent content of $\mathrm{Ni}$ and $\mathrm{Mn}$ stable below $480^{\circ} \mathrm{C}$, the phase $\eta$ "becomes", which gives the possibility to choose the aging modes of the alloys of this system. Property of alloy with mass content. \%: $60 \mathrm{Cu}, 20 \mathrm{Ni}$, $20 \mathrm{Mn}$ to strengthen aging was investigated in a number of papers in particular $^{54}$ to achieve the optimal complex of properties during aging

${ }^{54}$ Dea R., Long J., Graham T., Mathews C. Age Hardening Cu-Ni-Mn Alloys. Trans. ASM, 1945. Vol. 34. 
proposed to hold at $650{ }^{\circ} \mathrm{C}$ for 1 hour. Followed by cooling and aging at a temperature of $350-450{ }^{\circ} \mathrm{C}$ it is not recommended to raise the temperature for 24 hours, as it will result in grain growth and a decrease in the level of mechanical properties, the hardness of the treated according to the specified mode of the alloy is about 50 HRC. Metallographic studies of hardened alloys show that at temperatures up to $4000^{\circ} \mathrm{C}$, there is a new phase, both in the boundaries and inside the grains, which leads to their deformation, and at a temperature of $4500{ }^{\circ} \mathrm{C}$ and above, a new phase is observed only along the grain boundaries.

Experimental studies of aging of the alloy of the MNMts 60-20-20 grade have been carried out in ${ }^{55}$. In this case, the temperature range of the heating of the alloy under aging in the range of $600-800{ }^{\circ} \mathrm{C}$ was chosen for the results. The results show that the highest hardness has an alloy annealed at a $600{ }^{\circ} \mathrm{C}$ of $1 \mathrm{~h}$, tempered and aged at $400{ }^{\circ} \mathrm{C}$ for $20 \mathrm{~h}$. With the most intensive strengthening observed during the first 8 hours, metallographic studies show a high inhomogeneity along the grain boundaries, which is explained by the heterogeneity of the structure. Energy dispersive X-ray spectroscopy analysis of the aged alloy shows the presence of grains of the phase with a high content of Mn 30-31\% and $\mathrm{Ni} 47-50 \%$. Durometric analysis shows that the microhardness within the grains varies within $140-450 \mathrm{kgf} / \mathrm{cm}^{2}, 478-600 \mathrm{kgf} / \mathrm{cm}^{2}$. The total hardness is 28-37 HRC, while the impact strength of the alloy is reduced by $8 \mathrm{kgf} \times \mathrm{m} / \mathrm{cm}^{2}$, and the relative elongation from 14.5 to $2 \%$. It is proposed to use plastic deformation to improve the properties of the alloy.

\subsubsection{Metal-ceramic composites based on copper-nickel-manganese alloys}

Manganese cupronickels close to the specified (the grade MNMts 60-20-20) are widely used as components of wear-resistant materials on the basis of the tugsten carbides to deposite wear-resistant coatings for wearing parts of the metallurgical and oil and gas equipment by the method of surfacing with molten additive alloy ${ }^{56,57}$.

55 Петросянц А.А., Белоусов В.Я. Саркисов В.С. Повышение долговечности деталей газо-нефтепромыслового оборудования : монография. Москва : Недра, 1976. $211 \mathrm{c}$.

56 Патон Б.Е., Дудко Д.А., Максимович Б.И., Агафонов Н.Г. Наплавка намораживанием и заливкой расплавленного присадочного материала. Автоматическая сварка. Киев, 1966. № 11. С. 44-48.

57 Danilov, L.I., Rovenskikh, F.M. Surfacing of charging equipments ofblast Furnaces by a composite alloy. Metallurg. Москва, 1973. № 29. РP. 12-15. 
Such composite materials are in most cases referred to the macroheterophase type, because as a reinforcing phase, angular-shaped tungsten carbide is used in the form of a bulk form of particle size $0.2-2 \mathrm{~mm}^{5}$ or granules of solid alloys of the type VK and $\mathrm{TC}^{6}$. Such shape and particle sizes are not favorable in many cases, for example, for materials for tribotechnical purposes. The development of microheterophase-type composites in which the dimensions of the reinforcing ceramic component grains are much smaller than the grain of the disperse-hardening alloy - the bonds create the preconditions for the combination of dispersion and dispersion hardening in a monolithic material. In addition, the high dispersion of ceramic particles is conducive to the processes of structuring through the mechanism of dissolution and deposition and to ensure a strong connection between the phases due to limited solubility.

One of the methods for obtaining microheterophase composites is to infiltrate the pre-pressed and sintered porous ceramic skeletons. In this case, the ceramic phase must meet a number of criteria, the main of which is wettability of the melt of the binder and the absence of excessive chemical interaction with its components (except in cases where the products of the interaction are strengthening phases). Such requirements correspond in particular to refractory compounds (TS) of IV-VI groups of the periodic system of elements. The global trend towards rising prices for tungsten raw materials leads to the need to search for tungsten-free components of composite materials. The $(\mathrm{Ti}, \mathrm{Cr}) \mathrm{B}_{2}{ }^{58,59}$, the complex carbide $(\mathrm{Ti}, \mathrm{Cr}) \mathrm{C}^{60}$, and alloys of the Fe-B-C system ${ }^{61}$ were investigated as the reinforcing phase of the tungsten-free composites with metal binders.

58 Belousov V.Ya. Surfacing of charging equipments of blast Furnaces by a composite alloy. Soviet materials science. Lviv, 1979. Vol 15, № 5. PP. 512-514.

59 Белоусов В.Я. Долговечность деталей машин с композиционными материалами : монография. Львов : Вища школа, 1984. 180 с.

60 Спиридонова I., Сухова О. Композиційні матеріали 3 металевою матрицею, зміцнені частками $\mathrm{Cr}-20 \mathrm{Ti}-10 \mathrm{C}$. Фізика і хімія твердого тіла. ІваноФранківськ, 2002. Т. 3, № 3. С. 503-507.

61 Суховая Е.В. Структурный подход к созданию износостойких композиционных материалов. Сверхтвердые материалы. Киев, 2013. №5. С. 29-38. 


\section{The analysis of the techniques suitable for manufacturing tungsten-free composite mechanical seal faces and methods for investigation its physical and mechanical properties}

\subsection{Substantiation of the choice of the method of manufacturing rings and raw materials}

Among the methods of powder metallurgy, which are widely used for obtaining metal-ceramic materials of tribotechnical purpose with a manganese cupronickel binder, it is most rational to use the method of infiltration of the preformed porous frames, considering its advantages over traditional methods, namely:

- the possibility of manufacturing products of complex configuration;

- lack of shrinkage, which greatly simplifies the technology of manufacturing products;

- the possibility of using as a metal component of alloys, powders which are not produced serially. In this case, the metal components can be used in the form of waste, sludge, chips, etc., which significantly increases the profitability of the method;

- the simplicity of technology, which is ensured by the lack of laborintensive mixing and grinding operations of the original components and the use of standard furnace and press equipment;

- low process length, which, with the correct selection of components, ensures maximum complete preservation of their chemical composition, and, consequently, properties.

- low influence of harmful impurities (first of all, oxide phases), which during the passage of the melt front through the porous body are transferred to the surface of the products and further easily removed by mechanical treatment.

The choice of the carbide phase for cermets of tribotechnical purposes with a cupronickel manganese binder was carried out considering the following basic characteristics:

- high level of hardness and elasticity;

- high corrosion resistance and chemical stability;

- high thermal conductivity;

- wettability;

- low cost.

Such requirements can be most fully ensured by the use of refractory carbides IV-VI of the periodic table of elements. Tungsten monocarbide (WC) is the most common among these compounds due to the highest 
modulus of elasticity ( $720 \mathrm{GPa}$ ). However, the widespread use of tungsten solid alloys of WC-Co and WC-Ni systems for the manufacture of sealing rings of centrifugal pumps is in many cases not justified due to the worldwide trend of rising prices for tungsten raw materials. Over the past 5 years, prices for tungsten have increased by almost 2 times from $\sim 20$ to $\sim 40 \$ / 1 \mathrm{~kg}^{62}$, besides the main world exporter of tungsten raw materials $(84 \%)$ is the China, which at the same time is also its primary consumer (more than 50\% of world demand). Considering that the domestic market of the China is developing dynamically, the increasing share of tungsten raw materials is aimed at securing domestic needs, which in turn poses a threat to the tungsten sector outside the PRC due to a significant drop in supplies ${ }^{63}$. Therefore, in order to save energy resources, the search for alternative materials for tungsten hard alloys, in particular tribotechnical purposes, remains an urgent problem in the oil and gas industry. An alternative material for the production of sealing rings is the higher carbide chromium $\left(\mathrm{Cr}_{3} \mathrm{C}_{2}\right)$, which is characterized by a rather high level of physical and mechanical characteristics, along with a high corrosion resistance in various chemically active gas and liquid media $^{64}$. In addition, the cost of the metal component of chromium carbide is practically 10 times lower than that of tungsten carbide (Fig. 2.1), and its density is lower by about 2.3 times. At the same time, the level of mechanical properties of $\mathrm{Cr}_{3} \mathrm{C}_{2}$ is relatively high along with relatively high thermal conductivity (Table 2.1).

The important difference $\mathrm{Cr}_{3} \mathrm{C}_{2}$ from most refractory carbides IV-VI groups of the periodic system of elements is high wettability of copper and copper alloys. In this case chromium carbides are also characterized by the ability to form solid solutions with manganese carbides $^{65}$, whose microhardness is higher than the initial components, and its concentration dependences in the $\mathrm{Cr}_{3} \mathrm{C}_{2}-\mathrm{Mn}$ systems are described by curves with extremum ${ }^{66}$. This creates the prerequisites for increasing

62 Whittaker P. Global tungsten prices show signs of stabilising. Powder Metallurgy Review. 2014. vol. 4, №2. Р. 20.

63 Мировой рынок вольфрама. URL: http://www.cmmarket.ru/markets/ woworld.htm (дата звернення: 15.12.2018).

64 Панасюк А.Д., Фоменко В.С., Глебова Г.Г. Стойкость неметаллических материалов в расплавах: справочник. Киев : Наукова думка, 1986. 351 с.

65 Борисова А.Л. Совместимость тугоплавких соединений с металлами и графитом: справочник. Киев : Наукова думка, 1985. 247 с.

66 Гольдшмидт Ж. Дж. Сплавы внедрения (пер. с англ.) : монография. Москва : Мир, 1971. 424 с. 
the level of chromium carbide-based cermet properties due to their doping. The comparative analysis of carbides promising for use as a carbide phase of cermets for mechanical seals on wettability of copper and the values of their microhardness and thermal conductivity (Fig. 2.2) shows the most successful combination of the above characteristics characterized by vanadium carbide VC.

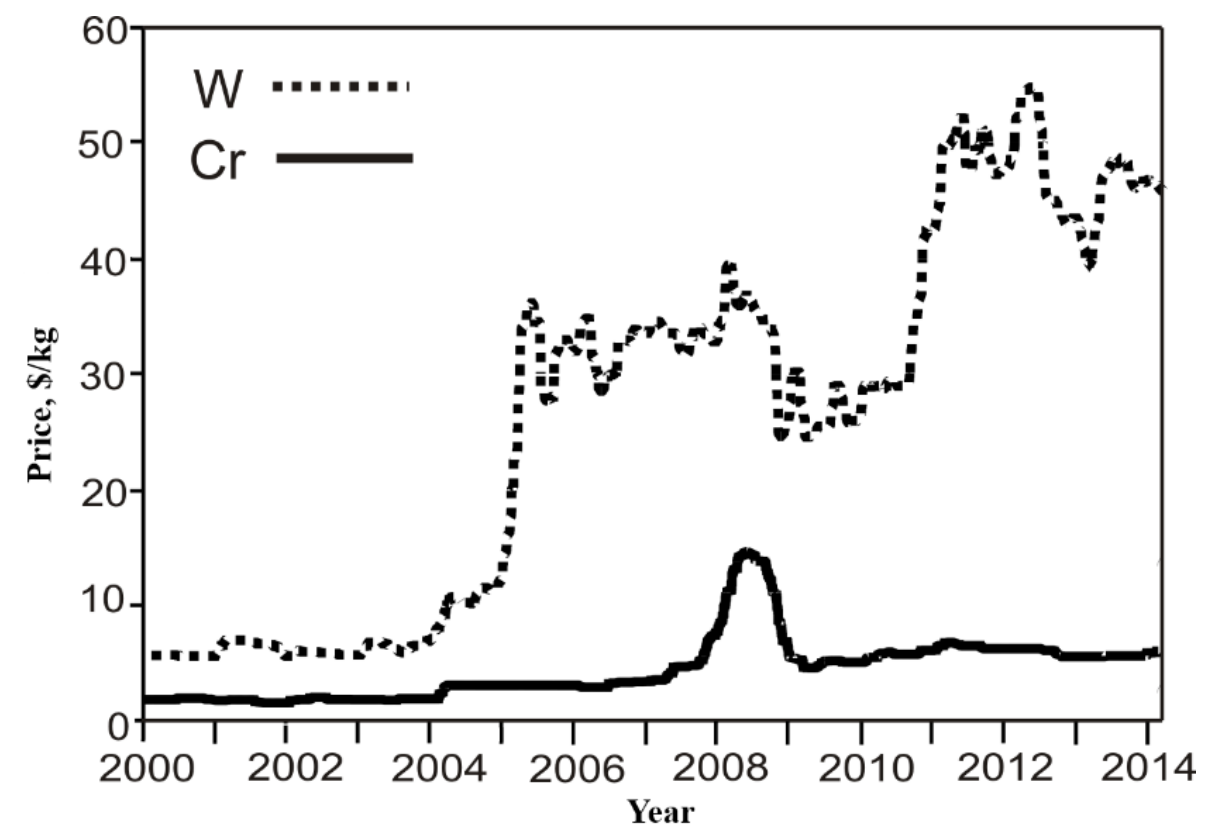

Fig. 2.1. Comparative characteristics of the dynamics of price growth on $\mathrm{W}$ and $\mathrm{Cr}^{67}$

Table 2.1

Comparative characteristic of the properties of tungsten and chromium carbides

\begin{tabular}{|c|c|c|c|c|c|}
\hline 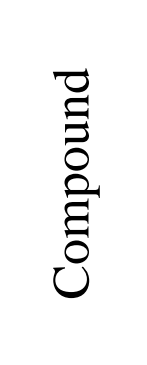 & 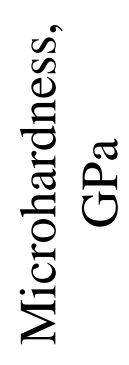 & 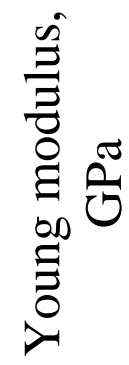 & 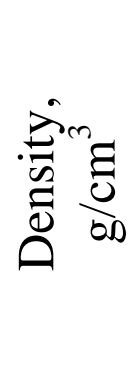 & 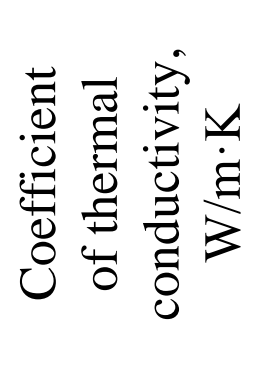 & 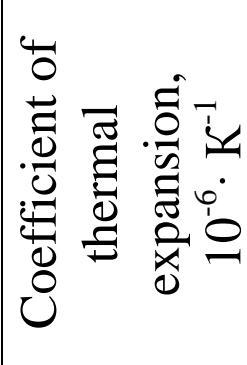 \\
\hline $\mathrm{Cr}_{3} \mathrm{C}_{2}$ & 18 & 380 & 6,7 & 13 & 11,7 \\
\hline $\mathrm{WC}$ & 17,1 & 710 & 15,7 & 29 & 3,9 \\
\hline
\end{tabular}

${ }^{67}$ Materials information system. URL: https://setis.ec.europa.eu/mis/material/ chromium (дата звернення: 15.12.2018). 


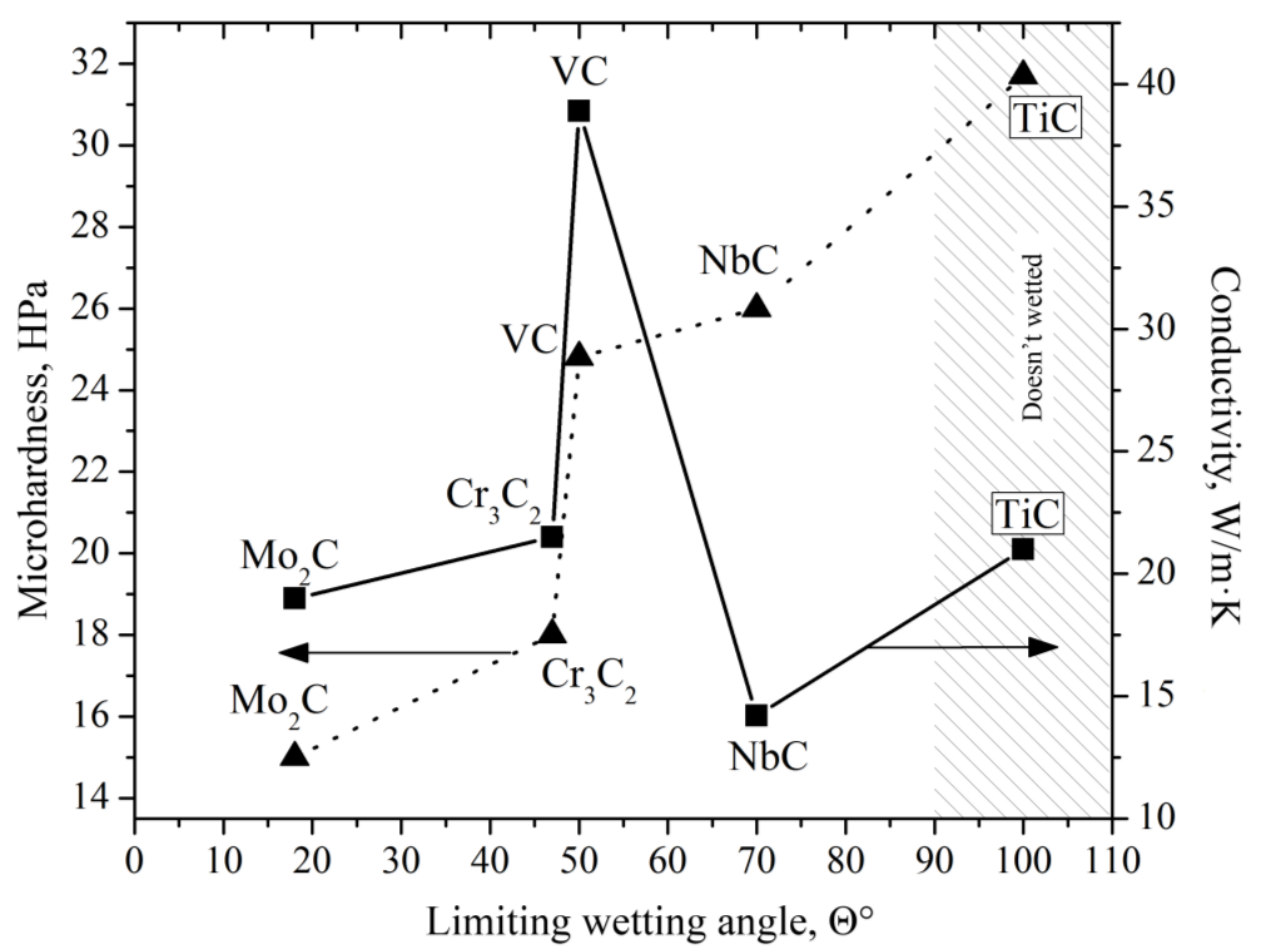

Fig. 2.2. Comparative characteristics of copper wettability, microhardness $(\Delta)$ and thermal conductivity $(\square)$ of some refractory carbides

However, the comparative analysis of the relative price of the metal components (considering their density) of the carbide phases (Fig. 2.3) shows that for $\mathrm{V}$ it is higher practically 3.5 times than for $\mathrm{Cr}$. Although the relative price $\mathrm{Ti}$ is lower than $\mathrm{Cr}$, almost twice the titanium carbide is not wetted with copper, which prevents the production of materials in the system TiC-manganese cupronickel.

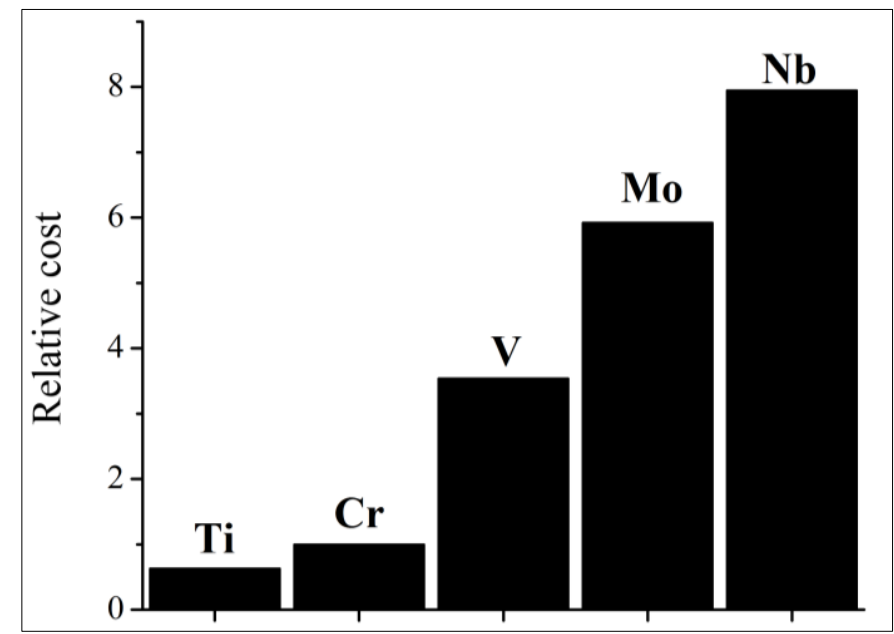

Fig. 2.3. Relative cost of metal components of carbide phases for use as material for rings of mechanical sealants 
Thus, based on the comparative analysis of the properties of the carbide phases, as well as the economic considerations of obtaining cermets for the manufacture of rings of mechanical seals, was carried out on the basis of the system: $\mathrm{Cr}_{3} \mathrm{C}_{2}-\mathrm{Cu}-\mathrm{Ni}-\mathrm{Mn}$.

\subsection{Selection of raw materials, their chemical composition, main characteristics and methods of manufacturing prototype samples}

As the initial carbide components for researches, powders $\mathrm{Cr}_{3} \mathrm{C}_{2}$ from TU 14-22-28-90 and TU 6-09-03-10-75 with a particle size average of 6 to $120 \mu \mathrm{m}$ were used. Their chemical composition is given in Table 2.2 and manganese cupronickel of the brand MNMts 60-20-20 for TU 48-21-486-75 (hereinafter referred to as the MNMTs) whose chemical composition is shown in Table 2.3, the main properties in Table 2.4.

Table 2.2

The chemical composition of the powder $\mathrm{Cr}_{3} C_{2}$, mass \%

\begin{tabular}{|c|c|c|c|c|}
\hline $\mathrm{Cr}$ & $\mathrm{C}$ & $\mathrm{Fe}$ & $\mathrm{Si}$ & $\mathrm{P}$ \\
\hline 86 & $12-14$ & 0,5 & 0,3 & 0,05 \\
\hline
\end{tabular}

Table 2.3

The chemical composition of the alloy MNMts, mass \%

\begin{tabular}{|c|c|c|c|c|}
\hline $\mathrm{Cu}$ & $\mathrm{Ni}$ & $\mathrm{Mn}$ & $\mathrm{Fe}$ & $\mathrm{Si}$ \\
\hline $58,5-60,1$ & $19,5-21,5$ & $19,5-21,5$ & up to 0,3 & up to 0,03 \\
\hline
\end{tabular}

Table 2.4

Physical, mechanical and technological properties of the alloy MNMts

\begin{tabular}{|l|c|}
\hline \multicolumn{1}{|c|}{ Properties or processing modes } & Value \\
\hline \multicolumn{1}{|c|}{ Physical properties } & 2 \\
\hline \multicolumn{1}{|c|}{ Pelting point, ${ }^{\circ} \mathrm{C}($ liquid$)$} & 1040 \\
\hline Specific mass $(\gamma), \mathrm{kg} / \mathrm{m}^{3}$ & 8260 \\
\hline Specific heat capacity $\left(c_{p}\right), \mathrm{kJ} /(\mathrm{kg} \cdot \mathrm{K})$ & 460 \\
\hline Specific electrical resistance $(\rho), \mu \mathrm{M} \cdot \mathrm{m}$ & 0,78 \\
after quenching & 0,57 \\
after quenching and aging & 12,5 \\
\hline Temperature coefficient of linear expansion $(\alpha), \times 10^{5}, \mathrm{~K}^{-1}$ & 24 \\
after quenching & 150 \\
after quenching and aging & \\
\hline Modulus of elasticity $(\mathrm{E}), \mathrm{HPa}$ & \\
\hline
\end{tabular}


Continuation of the table 2.4

\begin{tabular}{|l|c|}
\hline \multicolumn{1}{|c|}{1} & 2 \\
\hline \multicolumn{2}{|c|}{ Mechanical, technological properties or processing modes } \\
\hline $\begin{array}{l}\text { Boundary strength during stretching }\left(\sigma_{\mathrm{B}}\right), \mathrm{MPa} \\
\text { after quenching } \\
\text { after quenching and aging }\end{array}$ & $560 \ldots 610$ \\
\hline $\begin{array}{l}\text { Conditional yield point }\left(\sigma_{0,2}\right), \mathrm{MPa} \\
\text { after quenching } \\
\text { after quenching and aging }\end{array}$ & $1200 \ldots 1300$ \\
\hline $\begin{array}{l}\text { Relative elongation }(\delta), \% \\
\text { after quenching } \\
\text { after quenching and aging }\end{array}$ & $240 \ldots 320$ \\
\hline $\begin{array}{l}\text { Vickers hard }(\mathrm{HV}): \\
\text { after quenching } \\
\text { after quenching and aging }\end{array}$ & $4150 \ldots 1250$ \\
\hline $\begin{array}{l}\text { Quenching temperature, }{ }^{\circ} \mathrm{C} \\
\text { Aging temperature, }{ }^{\circ} \mathrm{C}\end{array}$ & $115 . \ldots 145$ \\
\hline $\begin{array}{l}\text { Alloy shrinkage, } \% \\
\text { after quenching } \\
\text { after quenching and aging }\end{array}$ & $370 \ldots 410$ \\
\hline
\end{tabular}

Samples for research were obtained by powder metallurgy in the following way: powders $\mathrm{Cr}_{3} \mathrm{C}_{2}$ different fractions were mixed in a gravitational drum mixer with a plasticizer (5\% solution of rubber SKK-3 GOST 14925-79 in petrol BR-1 (GOST 443-76) for $12 \mathrm{~h}$. The amount of plasticizer was $30 \%$ by volume of the powder. After drying the resulting mixture, its granulation was carried out by peeling through a sieve with a cell size of $1 \mathrm{~mm}$. The resulting pellets were pressed into the preforms of the required form by the method of single- and double-sided cold pressing in steel. The preforms produced in this way with an open porosity of $20-40 \%$ were placed in corundum crucibles with MNMts alloy weights (calculated for $100 \%$ pore filling). After that, the heating of the blanks in the vacuum furnace SSW-1,25/25-I1 was carried out (temperature control contour was performed using a tungsten-rhenium thermocouple VR5/VR20) with isothermal holdings according to the regime shown in (Fig. 2.4) ${ }^{68}$.

68 Шіхаб Таер Абдалвахаб Розроблення технології виготовлення кілець торцевих ущільнень відцентрових насосів із металокерамічних матеріалів на основі карбіду хрому. Науковий вісник ІФНТУНГ. Івано-Франківськ, 2016. № 1 (40). C. 41-49. 


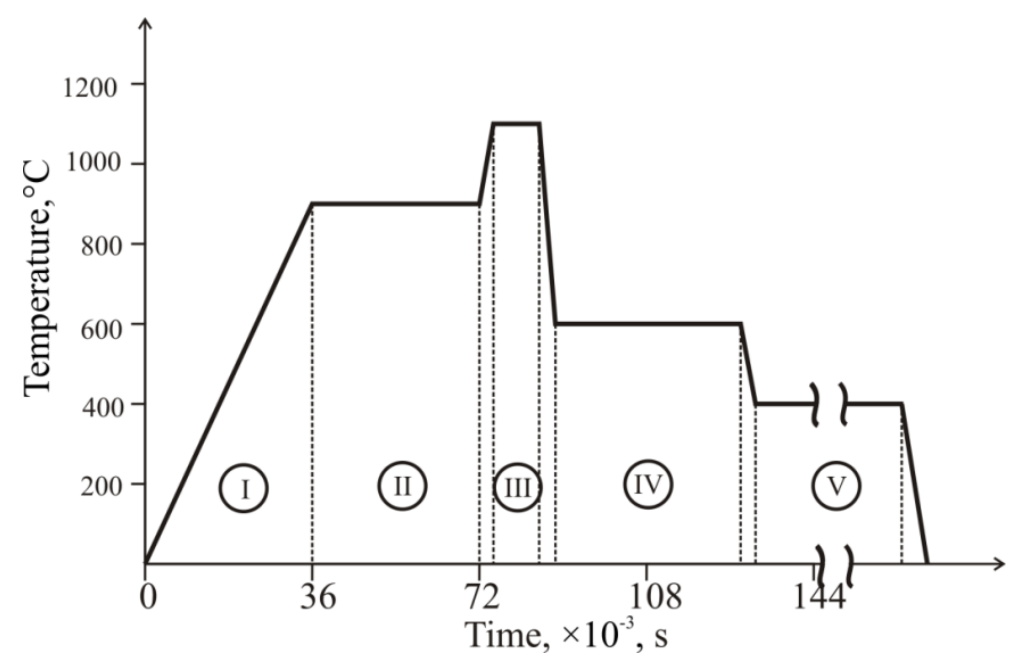

Fig. 2.4. Mode of obtaining experimental samples from cermets of the $\mathrm{Cr}_{3} \mathrm{C}_{2}$ system - MNMTs

At stage I, during slowly heating up to $900^{\circ} \mathrm{C}$, the removal of "light" fractions of plasticizer begins. Slow heating at this stage is necessary to preserve the original form of blanks, which, if heated rapidly, can be broken due to intense gas evacuation. At stage II, isothermal holding at $900{ }^{\circ} \mathrm{C}$ is carried out, during which the removal of "heavy" fractions of plasticizer, baking of particles and formation of morphology of capillaries in porous preforms takes place. After that, the heating was carried out to $1100{ }^{\circ} \mathrm{C}$ (step III) and isothermal exposure at that temperature. At this conditions melt of the MNMts alloy infiltrates into porous preforms. Further, after cooling to $600^{\circ} \mathrm{C}$, an isothermal holding was made to homogenize the alloy (Stage IV) and further cooling to $400{ }^{\circ} \mathrm{C}$ and isothermal holding at that temperature for $\sim 360 \cdot 10^{3} \mathrm{sec}$ to provide a dispersion strengthening of the binder due to the separation of intermetallics of the type $\mathrm{Mn}_{\mathrm{x}} \mathrm{Ni}_{\mathrm{y}}$ in aging (Stage V).

In order to choose the rational duration of isothermal aging after infiltration to prevent the development of undesired diffusion processes and obtaining a heterophase structure of the material, an estimate of the growth rate of the depth of the infiltrated layer was made. In this case, the infiltration kinetics was described by the equation derived from the Darcy's law, considering the morphology of the porous carbide framework and the temperature-concentration dependences of the surface tension of the MNMTs alloy according to Butler's equation ${ }^{69}$ and its viscosity using the JMatPro computer program ${ }^{70}$.

${ }^{69}$ Butler J. A. V. The thermodynamics of the surfaces of solutions. Proceedings of the Royal Society A, 1932. Vol. 135. PP. 348-375.

70 JMatPro practical software for materials properties. URL: http:// www.sentesoftware.co.uk/jmatpro.aspx (дата звернення: 15.12.2018). 


\subsection{Method of experimental studies of wetting and infiltration processes}

The prerequisite for obtaining products by the method of infiltration is wettability of the solid body of the melt. Wetting is a superficial phenomenon, which occurs at the interface of the phases, one of which is a solid, and the other is mutually insoluble melts, or melts and gas ${ }^{71}$. The infiltration can be of two types: immersion (the whole surface of the solid is in contact with the liquid) and contact. Contact wetting is a type of wetting, in which the third phase - gas or liquid - comes in contact with liquid and solids in a row.

After sintering in the volume of the porous body contains a large amount of impurities (Table 2.2, 2.3), which are concentrated on the boundaries of grains - through and closed pores. Their presence significantly reduces the level of strength and operational characteristics of materials. At infiltration, all pores are filled with melt. The impact of impurities at the same time decreases as they are absorbed by the liquid, evenly distributed in the volume of the body or transporting by melt on its surface.

The disadvantages of the infiltration process are explained by the complications caused by the following factors: the high temperature of the process, the possibility of the interaction of the porous frame with the alloy, which is used for the impregnation, the formation of new compounds, intermetallic phases and solid solutions, the possibility of interaction with the gas phase.

The pore filling of the liquid metal can be carried out unilaterally under the action of capillary pressure or forced by the action of external excess pressure.

The condition for the fluid to spill on a solid surface is the reduction of the free energy of the system $(F)$ with increasing the contact area of the liquid with a solid surface:

$$
d F<0 \text {. }
$$

For isothermal conditions and at constant volume (neglecting the change in the volume of phases), the change in the free energy of the system during the dispersal of the melt will be written:

${ }^{71}$ Найдич Ю.В., Колесниченко Г.А., Лавриненко И.А., Моцак Я.Ф. Пайка и металлизация сверхтвердых инструментальных материалов: монография. Киев : Наукова думка, 1977. 186 с. 


$$
d F=\sigma_{l g} d S_{l g}+\sigma_{s g} d S_{s l}+\sigma_{s g} d S_{s g},
$$

where $\sigma_{l g}, \sigma_{s l}, \sigma_{s g}$ - the free energy of the distribution surface of the liquid gas, solid - liquid, solid - gas, respectively; $S_{l g}, S_{s l}, S_{s g}$ - corresponding sections of the section.

When the liquid is spreading over the surface of a solid:

$$
d S_{l g}=S_{s l}=-d S_{m 2},
$$

considering (2.2) the condition of spontaneous wetting will be written as:

$$
\sigma_{l g}+\sigma_{s l}+\sigma_{s g}<0
$$

For a constant equilibrium case $\left(\Theta>0^{\circ}\right)$, based on the minimum $F$, that is:

$$
d F=0 .
$$

Given $d S_{l g}=d S_{s l} \cdot \cos (\Theta)$, we can obtain the expression for $\cos \theta$ through the vertices $\sigma_{l g}, \sigma_{s l}, \sigma_{s g}$ :

$$
\cos (\theta)=\left(\sigma_{s l}-\sigma_{s l}\right) / \sigma_{l g} .
$$

Equation (2.6) is called the second law of capillarity and is valid for any capillary systems.

To characterize the coupling forces of the fluid and the Dupree solid, we introduced the value the work of adhesion $W_{a}$, which is equal to the operation of their section along the interphase boundary:

$$
W_{a}=\sigma_{s g}+\sigma_{l g}-\sigma_{s l} \text {. }
$$

The work of adhesion is expressed through the edge angle $\Theta$ by the equation:

$$
W_{a}=\sigma_{l g}(1+\cos (\Theta)),
$$

which are usually used to calculate the cohesion energy between a solid surface and a fluid according to experimentally determined values $\sigma_{l g}$ and $\Theta$.

At $\Theta<90^{\circ}(\cos (\Theta)>0)$, the liquid metal moistens the substrate and then there will be unwanted leakage. The magnitude of the angle $\Theta$ is the main characteristic that affects the formation of the structure, and, consequently, the strength and exploitation properties of the composite.

The study of the wetting process obtained by sintering the chromium carbide, the melt of the alloy was carried out by the method of a dropping drop on the installation, the scheme of which is presented in fig. 2.5.

The samples of the substrate with a relative density of $0.8-0.9$ were thoroughly polished and rinsed in alcohol. The wetting alloys were prepared by a remelting method in a vacuum. Experiments were 
conducted in a vacuum at melting temperatures and a significant overheat of alloys at $50-100^{\circ} \mathrm{C}$ above liquidus.

The change in the value of the wetting angle, depending on the temperature, was fixed on the matte glass - a screen with an exposure at this temperature to the establishment of the equilibrium value.

When increasing the image of a drop 8-10 times the installation allows to determine the value of the angle $\Theta$ with an accuracy of $\pm 1^{\circ}$.

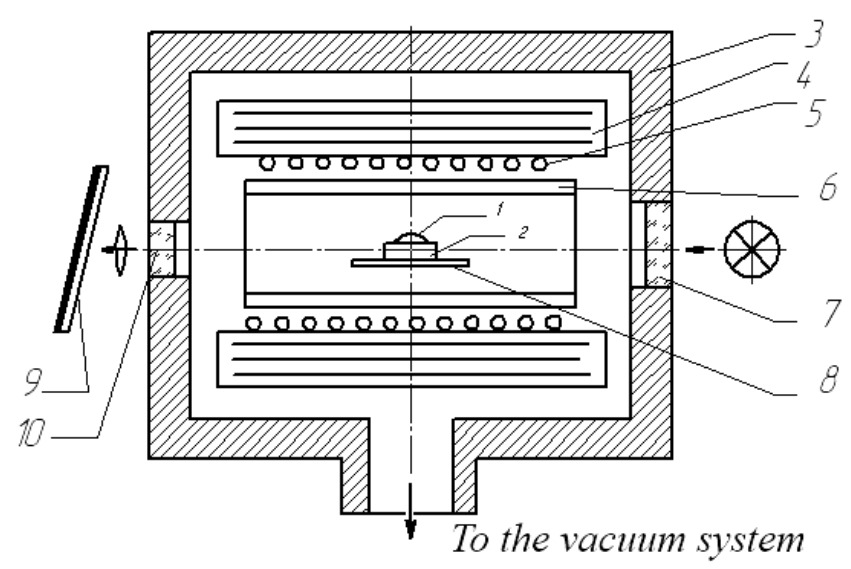

Fig. 2.5. Installation for determining the marginal angle of wetting of chromium carbide by molten alloys

1 - a drop, 2 - a substrate, 3 - a body, 4 - a screen, 5 - an heater,

6 - a fireproof tube, 7 - an entrance light window, 8 - a stand,

9 - a matte glass, 10 - an outgoing light window

Investigation of the infiltration kinetics of porous chromium carbide was carried out on an installation mounted on the vacuum furnace (Fig. 28). The construction is simple in the manufacture and operation, provides vertical displacement of the fixed sample in relation to the mirror of the melt, equipped with a device for automatically calculating the time of infiltration. The rate of infiltration was determined by the growth rate of the mass of the infiltrated sample.

An analytical description of the infiltration kinetics was carried out using the equation based on the Darcy law for the stationary laminar flow of non-compressible liquid, which has the form:

$$
\frac{d h(t)}{d t}=\frac{k \Delta P}{\mu h(t) \Pi},
$$

where $\frac{d h(t)}{d t}-$ the volume velocity of the molten penetration; $\Delta P-$ pressure drop; $\mu$ is the dynamic viscosity of the melt; $h$ - height of the porous 
body; $t$ - time; $k$ - coefficient of permeability, considering the geometry of the porous body capillaries; $\mathrm{P}$ - porosity.

The picture of the distribution of the infiltrating alloy in the sample was obtained by using of a metallographic study of its surface.

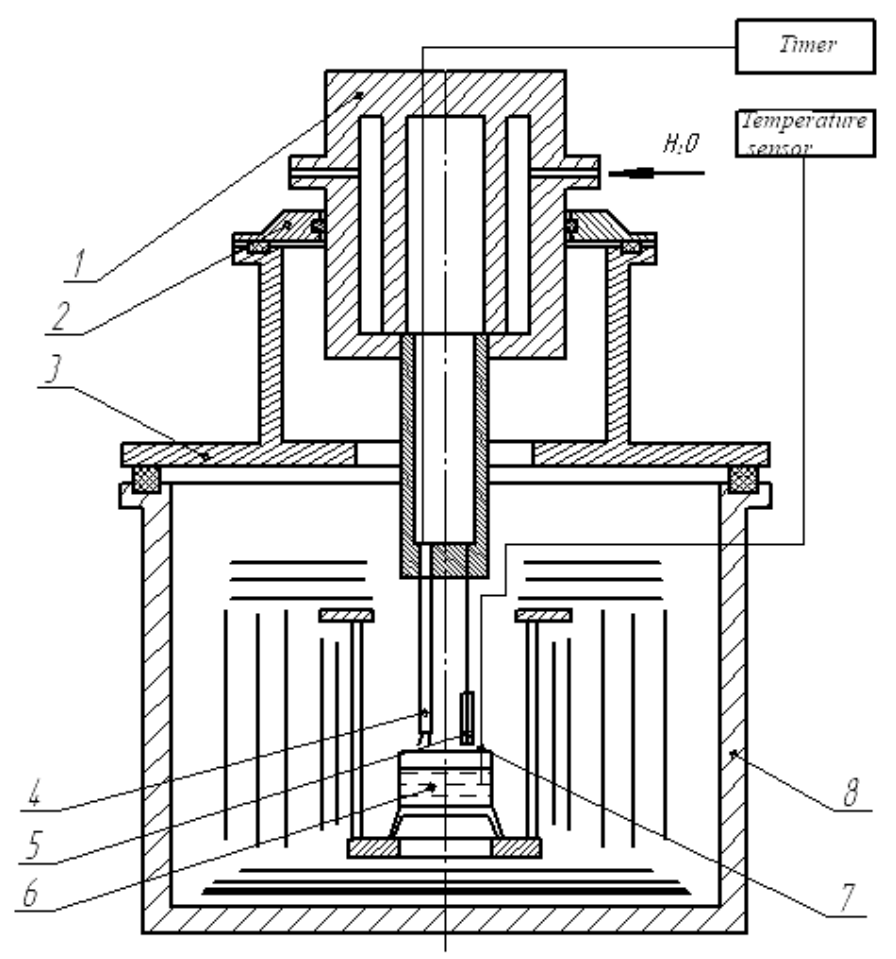

Fig. 2.6. Installation for studying the infiltration process

1 - polished water cooled moving stem, 2 - a flange with a vacuum-guiding guide, 3 - a removable cover, 4 - a ceramic trough with a separated contactor,

5 - a porous sample, 6 - a bath with a liquid meta-alloy melt,

7 - a thermocouple, 8 is the furnace body of the SSHL

Practically the process of obtaining metal-ceramic materials by infiltration consists of the following main stages:

1) preparation of a porous frame made of carbide of chromium;

2) filling the pores between the grains by molten alloy;

3) heat treatment of the obtained product.

Actually, the third stage of the process determines the structure, and hence the properties of the resulting composite material.

In the presence of a partial solubility of a solid component in a plastic metal matrix, the transition layer resulting from the thermo-shrinkage must have a chemical affinity for both components of the cermet, which increases adhesion at the boundary of the phase separation and promotes the obtaining of a strengthened matrix-reinforced composite-type structure with high physical and mechanical properties. 


\subsection{Method of modeling the structure of the material of the seal faces and its thermophysical characteristics}

To detect the shape and size of the structure components, as well as the bonding between them, electron microscopic studies were carried out using a CarlZeiss scanning electron microscope, which includes an EVO 40XVP base unit capable of operating in high vacuum, low vacuum and ultra-low vacuum modes with: detector-frame: secondary electrons of Ewernhart-Thornley (SE); 4-segment detector of reflected electrons (BSD) and secondary electrons for low vacuum (VPSE); absorbent current detector; infrared camera to monitor the position of the sample in the microscope chamber. The results of electron microscopic studies were analyzed using the SmartSEM software ${ }^{72}$.

X-ray phase analysis was performed on a DRON-3 diffractometer, in filtered $\mathrm{CuK} \alpha$ radiation, and also in MoK $\alpha 1$ radiation by focusing on the Breg-Brentano method and using a differential $\mathrm{Zr}$ filter. The duration of exposure shifted to a minimum statistical error of $0.1 \%$, and the results were taken at points in increments of 0.05 . The results of the analysis were conducted using the Match! software, as well as FullProf, which provided a full analysis using Rietveld method.

The EDS spectral analysis was performed using an IN-ENERGY 350 energy-doped X-ray spectrometer together with a $10 \mathrm{~mm}$ lithium detector, providing a resolution of $133 \mathrm{eV}$, a $0.01 \%$ admixture sensitivity, an analysis location of $1 \mu \mathrm{m}$ on standard models and up to $0.1 \mu \mathrm{m}$ on films. Spectrum analysis was conducted using Inca Energy software ${ }^{73}$.

The nature of the distribution of the structural components of the material in size was carried out by random method, in which the length of the chord was measured, which was cut off contours in planes. According to the principles of stereometrics metallography ${ }^{74}$, the number of planes was $>100$, and the number of size groups did not exceed 12 . The analysis was carried out on electron microscopic images of the reflected electrons obtained in the diffraction mode, which allowed to determine the contrast between the phases depending on density and eliminate the errors caused

72 SmartSEM - Zeiss. URL: http://www.zeiss.com/microscopy/ en_de/products/ microscope-software/smartsem.html (дата звернення: 15.12.2018).

73 INCA Energy - Oxford Instruments Nano Analysis. URL: http://www.oxinst.ru/ html/EnergySEM.htm (дата звернення: 15.12.2018).

${ }^{74}$ Салтыков С.А. Стереометрическая металлография: монография. Москва : Металлургия, 1976. 271 с. 
by the relief of the surface. The processing of the results was carried out using the ImageJ software ${ }^{75}$.

For heat calculations, the structure of the material of the rings was motivated by analyzing their cuts in the plane of the grinding, followed by the approximation of the contours of the structural components using the Freeman chain $^{76}$. According to which the analytic dependence describing the contour of the image is presented in the form of parametric equations:

$$
\begin{aligned}
& x_{p}=x_{c}+\sum_{n=1}^{\infty} a_{n} \cos \left(\frac{2 n \pi t_{p}}{T}\right)+b_{n} \sin \left(\frac{2 n \pi t_{p}}{T}\right), \\
& y_{p}=y_{c}+\sum_{n=1}^{\infty} c_{n} \cos \left(\frac{2 n \pi t_{p}}{T}\right)+d_{n} \sin \left(\frac{2 n \pi t_{p}}{T}\right),
\end{aligned}
$$

where $x_{c}$ and $y_{c}$ are the coordinates of the center of mass of the particle $n$ - the harmonic number, $t_{p}$ - the reflection from the starting point to the given point $\mathrm{p}, \mathrm{T}$ is the perimeter of the contour circuit.

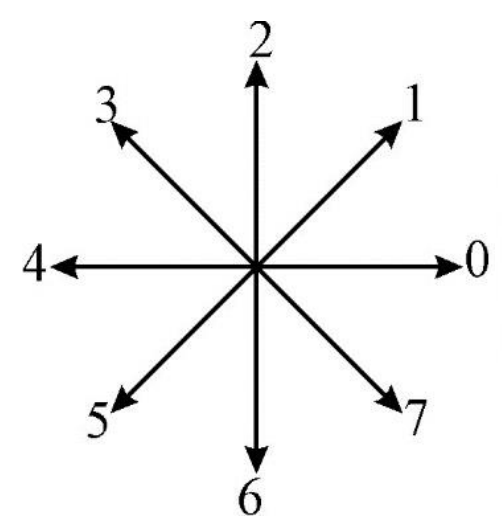

a

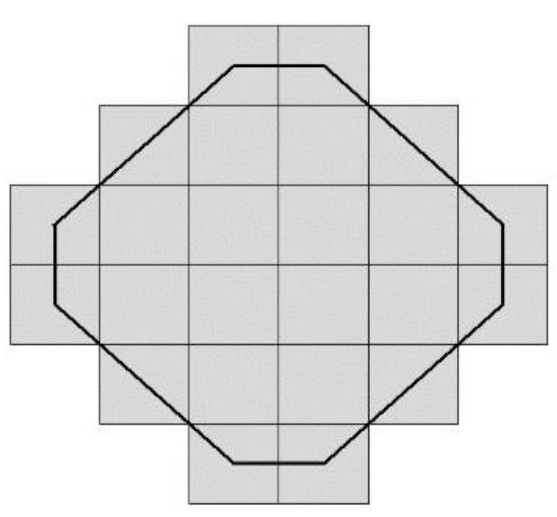

b

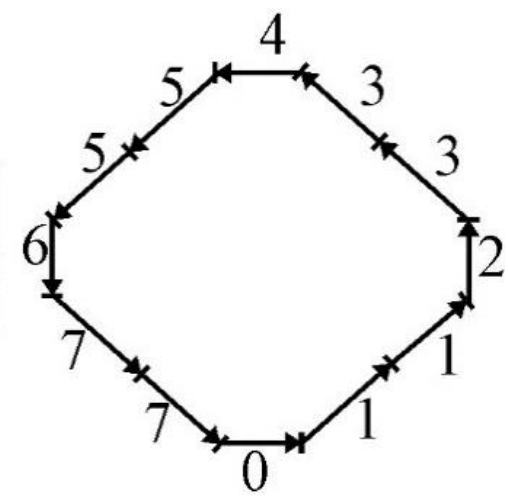

c

Fig. 2.7. Scheme of approximation of the contour of a discrete image using Freeman chain code:

$a$-direction vectors; $b$-image of the object in pixels; $c$ - the contour of the chain code

${ }^{75}$ Li K., Gao X. W., Yang W. B., Dai Y. L. Multiple fault diagnosis of down-hole conditions of sucker-rod pumping wells based on Freeman chain code and DCA. Petroleum Science, 2013. Vol. 10, № 3. PP. 347-360.

${ }^{76}$ Iwata H., Ukai Y. SHAPE: a computer program package for quantitative evaluation of biological shapes based on elliptic Fourier descriptors. Journal of Heredity, 2002. Vol. 93, № 5. PP. 384-385. 
Fourier coefficients $\left(a_{n}, b_{n}, c_{n}, d_{n}\right)$ are calculated by the formulas:

$$
\begin{aligned}
& a_{n}=\frac{T}{2 n^{2} \pi^{2}} \sum_{p=1}^{K} \frac{\Delta x_{p}}{\Delta t_{p}}\left(\cos \left(\frac{2 n \pi t_{p}}{T}\right)-\cos \left(\frac{2 n \pi t_{p-1}}{T}\right)\right), \\
& b_{n}=\frac{T}{2 n^{2} \pi^{2}} \sum_{p=1}^{K} \frac{\Delta x_{p}}{\Delta t_{p}}\left(\sin \left(\frac{2 n \pi t_{p}}{T}\right)-\sin \left(\frac{2 n \pi t_{p-1}}{T}\right)\right), \\
& c_{n}=\frac{T}{2 n^{2} \pi^{2}} \sum_{p=1}^{K} \frac{\Delta y_{p}}{\Delta t_{p}}\left(\cos \left(\frac{2 n \pi t_{p}}{T}\right)-\cos \left(\frac{2 n \pi t_{p-1}}{T}\right)\right), \\
& d_{n}=\frac{T}{2 n^{2} \pi^{2}} \sum_{p=1}^{K} \frac{\Delta y_{p}}{\Delta t_{p}}\left(\sin \left(\frac{2 n \pi t_{p}}{T}\right)-\sin \left(\frac{2 n \pi t_{p-1}}{T}\right)\right),
\end{aligned}
$$

where $\Delta x_{p}, \Delta y_{p}, \Delta t_{p}$ is the displacement of the $\mathrm{i}$-th point relative to $(i+1)-y$ relative to the $x, y$ axis and contour, respectively; $K$ is the total number of points forming the contour.

The determination of the thermophysical properties of the material was carried out according to the following algorithm:

1) using the SHAPE program (the ChainCoder module for randomly selected grains in the structure snapshots, their Freeman chain codes were determined, after which the contour reconstruction was carried out.

2) using the SHAPE module CNC2NEF, three-mass grains were found, their largest radiuses, which were located on the abscissa axis, and the Fourier coefficients of each grain $\left(a_{n}, b_{n}, c_{n}, d_{n}\right)$ for 50 harmonics.

3) calculation the arithmetic mean of the coefficients $\left(a_{n m}, b_{n m}, c_{n m}\right.$, $\mathrm{d}_{\mathrm{nm}}$ ) for the analyzed particle area, which was subjected to equation (2.10), while taken $\frac{2 n \pi t_{p}}{T}=\theta_{i}$, where $\theta_{i}$ is the angle of the radius vector, which varied from 0 to $2 \pi$ in step 0,01 radian. $x_{c}$ and $y_{c}$ were taken equal to 0 . Thus, the parametric equations for the description of the contour acquire the form:

$$
\begin{aligned}
& x\left(\theta_{i}\right)=\sum_{n=1}^{50} a_{n m} \cos \left(n \theta_{i}\right)+b_{n m} \sin \left(n \theta_{i}\right), \\
& y\left(\theta_{i}\right)=\sum_{n=1}^{50} c_{n m} \cos \left(n \theta_{i}\right)+d_{n m} \sin \left(n \theta_{i}\right),
\end{aligned}
$$

which made it possible to present a contour of the average form of a particle in polar coordinates with a radius vector $R\left(\theta_{i}\right)=\sqrt{x\left(\theta_{i}\right)^{2}+\mathrm{y}\left(\theta_{i}\right)^{2}}$. 
4) The resulting medium contour was translated into threedimensional space and into three mutually perpendicular directions using the Digimat 6.1 software. And determined the thermophysical properties of the resulting spatial structure by the Morie-Tanaka algorithm ${ }^{77}$.

\subsection{Method of thermal calculation of rings of face sealants from composites $\mathrm{Cr}_{3} \mathrm{C}_{2}-\mathrm{Cu}-\mathrm{Ni}-\mathrm{Mn}$ in pairs with self-bonded $\mathrm{SiC}$}

The process of propagation of heat at the friction of the rings was described by a scheme in which two half-infinite rods of the radius of the same size, but with different heat-physical properties, are in contact with a source with a specific energy $\mathrm{q}(\mathrm{t})\left(\mathrm{J} / \mathrm{s} \cdot \mathrm{cm}^{2}\right)$ (Fig. 2.8).

The superficial heat transfer of the rods along the length was considered by negative Wi sources, which were written as:

$$
c_{i} \rho_{i} \frac{\partial T_{i}(x, t)}{\partial t}=\lambda_{i} \frac{\partial^{2} T(x, t)}{\partial t}-W_{i} . \quad(i=1,2) .
$$

The sources of Wi express the amount of heat that is deducted from the volume unit $\left(\mathrm{J} / \mathrm{s} \cdot \mathrm{cm}^{3}\right)$ for the length of the contact 21 will be:

$$
W_{i}=\frac{2 \alpha T(x, t)}{l},
$$

where $\alpha$-coefficient of heat exchange, $\mathrm{W} / \mathrm{m}^{2} \cdot \mathrm{deg}$. After substituting into equation (2.13) we obtain:

$$
c_{i} \rho_{i} \frac{\partial T_{i}(x, t)}{\partial t}=\lambda_{i} \frac{\partial^{2} T(x, t)}{\partial t}-\frac{2 \alpha T(x, t)}{l} .
$$

Enter the notation $a_{i}=\frac{\lambda_{i}}{c_{i} \rho_{i}}$ and $b_{i}=\frac{2 \alpha}{c_{i} \rho_{i} l}$ the mathematical formulation of the original problem will have the form:

$$
\begin{aligned}
& \frac{\partial T_{1}(x, t)}{\partial t}=a_{1} \frac{\partial^{2} T(x, t)}{\partial t}-b_{1} T_{1}(x, t) \quad t>0 \quad-\infty<x<0 ; \\
& \frac{\partial T_{2}(x, t)}{\partial t}=a_{2} \frac{\partial^{2} T(x, t)}{\partial t}-b_{2} T_{2}(x, t) \quad t>0 \quad 0<x<\infty ;
\end{aligned}
$$

${ }^{77}$ Mori T., Tanaka K. Wetting Average stress in the matrix and average elastic energy of materials with misfitting inclusions. Acta metallurgica. 1973. Vol. 21, № 5. PP. 571-574. 


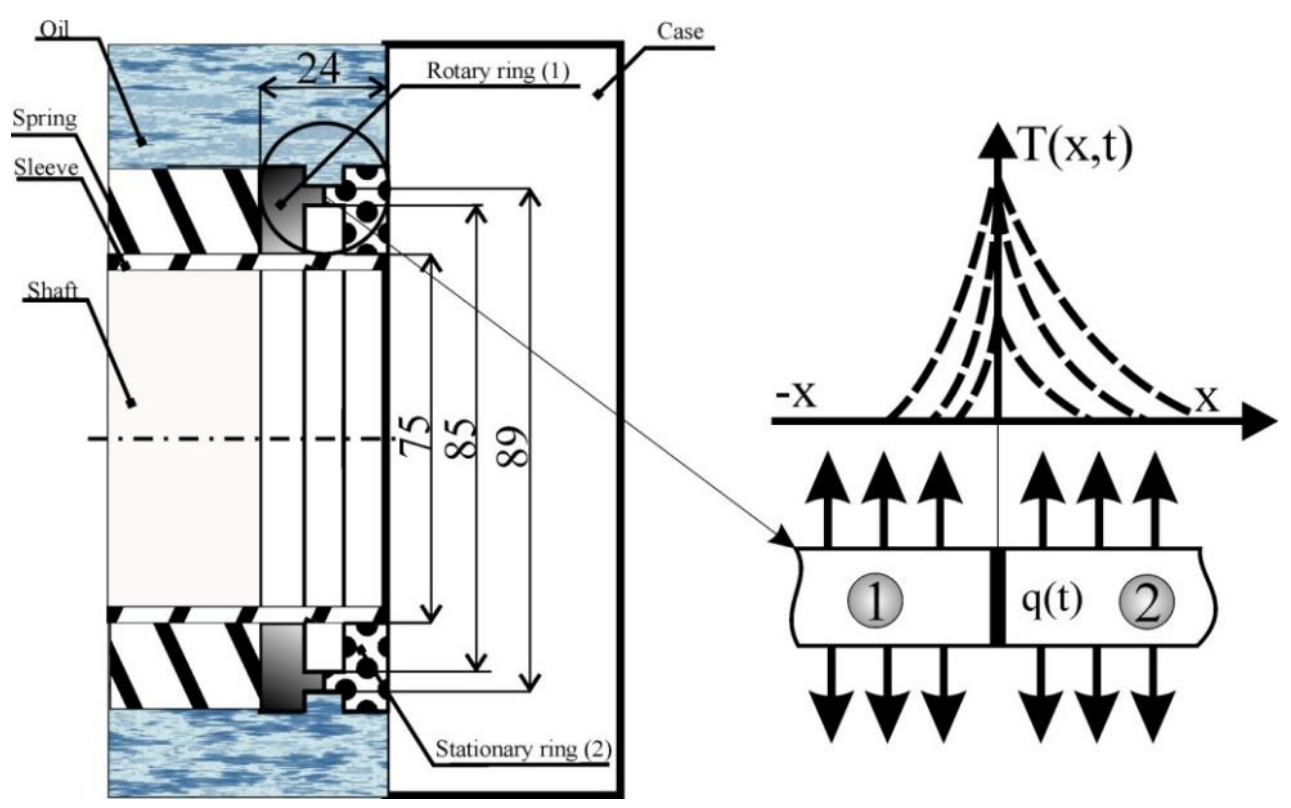

Fig. 2.8. Scheme for calculating the heat flow in the friction of rings of mechanical seals

1 - a moving ring; 2 - a fixed ring

The boundary conditions that determine the conditions for the continuity of the temperature field and the heat exchange on the contact surfaces for the solution of the problem will have the form:

$$
\begin{gathered}
T_{1}(x, 0)=T_{2}(x, 0)=0 ; \quad T_{1}(0, \mathrm{t})=T_{2}(x, \mathrm{t}) ; \\
\lambda_{1} \frac{\partial T_{1}(0, t)}{\partial x}-\lambda_{2} \frac{\partial T_{2}(0, t)}{\partial x}=q(t) ;
\end{gathered}
$$

\subsection{Method for determination of mechanical properties of $\mathrm{Cr}_{3} \mathrm{C}_{2}$-composites- $\mathrm{Cu}$-Ni-Mn}

Durometric studies were performed using microdermabrasion PMT-3 equipped with a digital camera-spectacle USMOS05100KPA, the load on the indenter was from 0.5 to $2 \mathrm{~N}$. The values of microhardness were calculated based on the results of three prints using the formula:

$$
H_{\mu}=1,854 \frac{F \cdot 10^{5}}{d^{2}},
$$

where $\mathrm{H}_{\mu}$ is microhardness, MPa; $\mathrm{F}-$ load, $\mathrm{N}$; $\mathrm{d}$ is the diagonal of the pyramidal imprint of $\mu \mathrm{m}$.

The hardness of the Rockwell method was measured on a standard scale of GOST 9013-59 (ISO 6508-86) on a solid-state TK-2 scale. 
The determination of the bending strength $\left(R_{b m}\right)$ occurred in the method of three-point bending according to GOST 20019-74 on samples measuring $5 \times 5 \times 35 \mathrm{~mm}$, the distance between the fixed supports was $l=25 \mathrm{~mm}$. The calculation was carried out according to the formula:

$$
R_{b m}=\frac{3 P l}{\left(2 b h^{2}\right)}
$$

where $\mathrm{P}$ is a destructive effort, $\mathrm{N} ; \mathrm{b}$ - sample width, $\mathrm{mm} ; \mathrm{h}$ - sample height, mm.

For the estimation of the crack strength, the critical coefficient of intensity of stresses I of the deformation mode $\left(K_{I c}\right)$ according to the indirect method of Evan-sa-Charles was calculated on the basis of the results of measuring the lengths of cracks obtained from the cut of the diamond pyramid of Vickers. Measurements were made on TP-7P-1 hardness tester at a load of $\sim 600 \mathrm{~N}$, and the calculation according to the formula:

$$
K_{1 c}=0,075 \frac{P}{C^{\frac{3}{2}}},
$$

where $K_{I c}$ is the coefficient of crack resistance, $\mathrm{MPa} \cdot \mathrm{m}^{1 / 2} ; \mathrm{P}-$ load on the indenter, $\mathrm{N}$; $\mathrm{C}-$ the length of the crack is measured from the middle of the imprint (Fig 2.9).

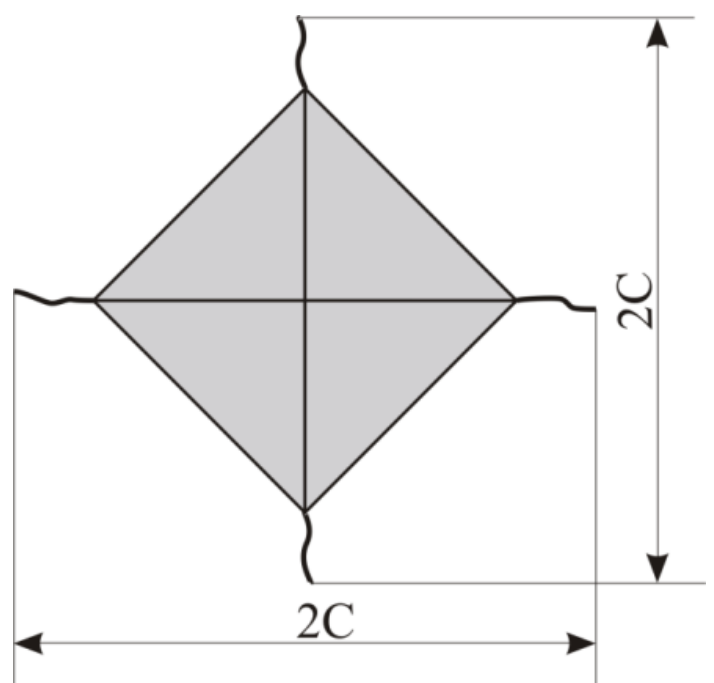

Fig. 2.9. Scheme for measuring the lengths of cracks in determining the friction resistance 


\subsection{Method of determination of tribotechnical properties and wear resistance}

The wear resistance in conditions of slip friction was carried out according to the scheme "cylinder-plane" on the machine SMTS-2 ${ }^{78}$. For researches samples from cermets of prismatic form in the size $20 \times 10 \times 5 \mathrm{~mm}$ were made. As a counterpart, a 45 HRC steel roller (Fig. 2.8) hardened to hardness was used which run over the frequency $n=300 \mathrm{~min}^{-1}$. The friction load P was 50 to $200 \mathrm{~N}$, the test duration for each load was $600 \mathrm{~s}$.

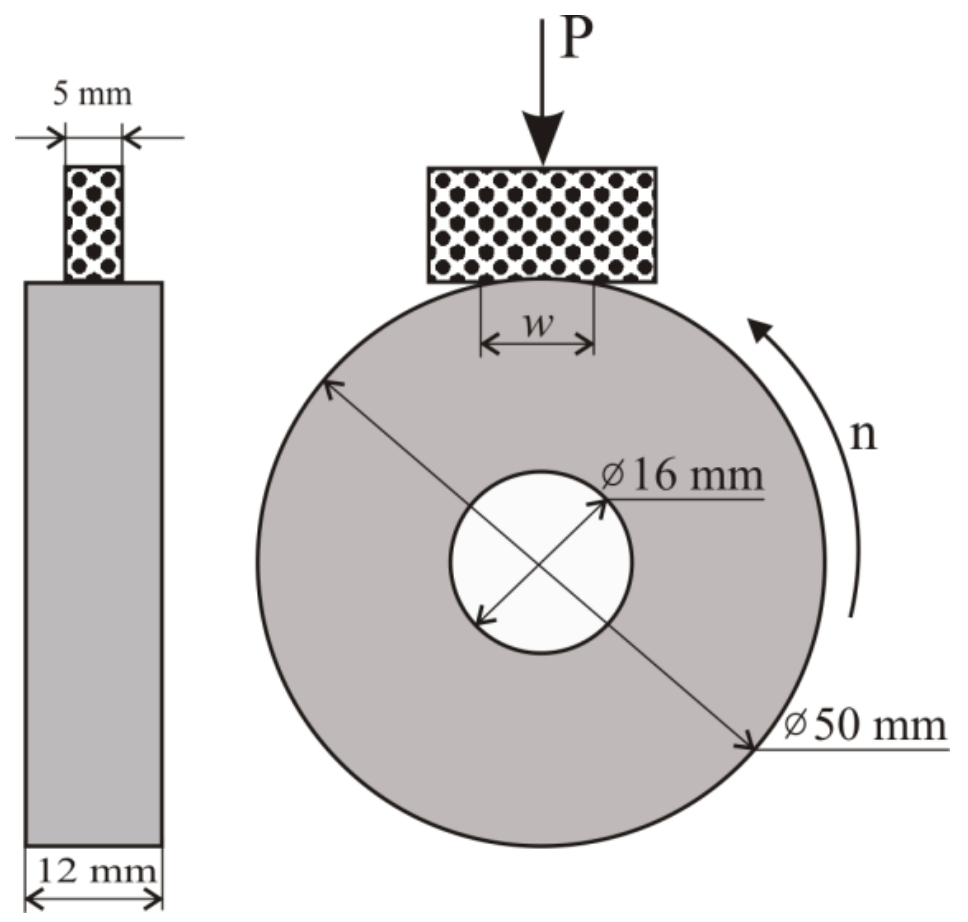

\section{Fig. 2.10. Diagram of determination of wear resistance in conditions of sliding friction}

Temperature recording in the friction zone was performed automatically with using thermocouple conected to a digital UT-78B multimeter with further processing of data on a personal computer. The thermocouple was placed at a distance of $1 \mathrm{~mm}$ from the zone of friction contact.

The wear resistance of was estimated by the value of the volumetric intensity of wear $I_{v}$ according to the formula ${ }^{79}$ :

78 Присяжнюк П.М., Бурда М.Й. Триботехнічні властивості карбідосталі NbC-сталь Гадфільда. Проблеми трибологї. Хмельницький, 2016. № 1. С. 88-94.

79 Гинзбург Б.М., Точильников Д.Г. Влияние фуллереносодержащих добавок к фторопластам на их несущую способность при трении. Журнал технической физики. Санкт-Петербург, 2001. Т.71 № 2. С. 120-124. 


$$
I_{v}=\frac{\Delta V}{L}=\frac{b S}{L}=\frac{b\left(R^{2} \arcsin \left(\frac{w}{2 R}\right)-\frac{R w}{4} \sqrt{4-\frac{w^{2}}{R^{2}}}\right.}{L},
$$

where $b$ is the width of the side of the model in contact with the counter body, $\mathrm{S}$ is the area of the grated segment, $\Delta \mathrm{V}$ is the volume of the worn material, $\mathrm{L}$ is the friction path, and $\mathrm{R}$ is the radius of the counter body.

The value of the pressure $p$ in the friction pair during the test process, considering the values of the hole as wear on completion of each of the stages of nautical loading, was calculated by the formula:

$$
p=\frac{F}{2 b \operatorname{Rarcsin}\left(\frac{w}{2 R}\right)} .
$$

Determination of the frictional heat resistance of the obtained materials was carried out at the 2168 UMT- 1 installation, according to the pattern of end friction (Fig. 2.11) using the method RD-50-662-88 ${ }^{80}$ in the identical cermet pairs and pairs with a self-bonded silicon carbide. Samples for research were rotary and fixed hollow cylinders with holes (on a fixed sample) for the installation of thermocouples (Fig. 2.12).

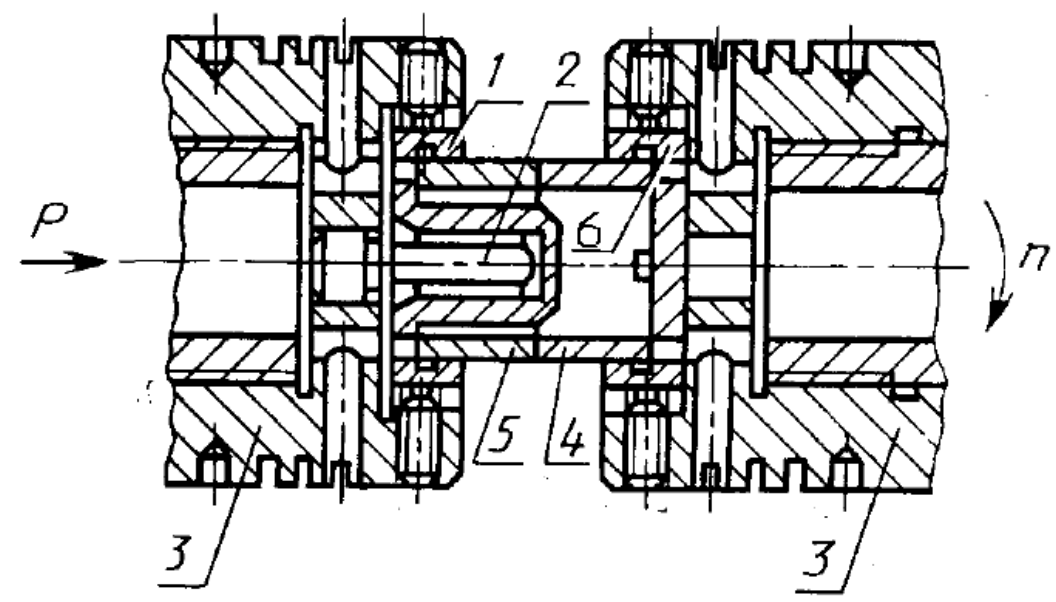

Fig. 2.11. Scheme of testing for frictional heat resistance:

1, 6 - sockets for test specimens; 2 - hinge assembly of samples; 3 -roll-up for the installation of samples; 4 - a moving sample; 5 - fixed sample

${ }^{80}$ РД 50-662-88 Методические указания. Методы экспериментальной оценки фрикционной совместимости материалов трущихся сопряжений URL: https:// ohranatruda.ru/ot_biblio/norma/555613/ (дата звернення: 15.12.2018). 
The test was carried out by frictional warming, provided with different slip rates, namely 50, 200, 500, 1000, 1500, 2000 and 2500. The duration of the test at each load level was taken 900 s. Subsequently, the samples were withdrawn from the conjugate, cooled to room temperature and weighed to an accuracy of $0.001 \mathrm{~g}$. The specific load on the pair was $1 \mathrm{MPa}$.

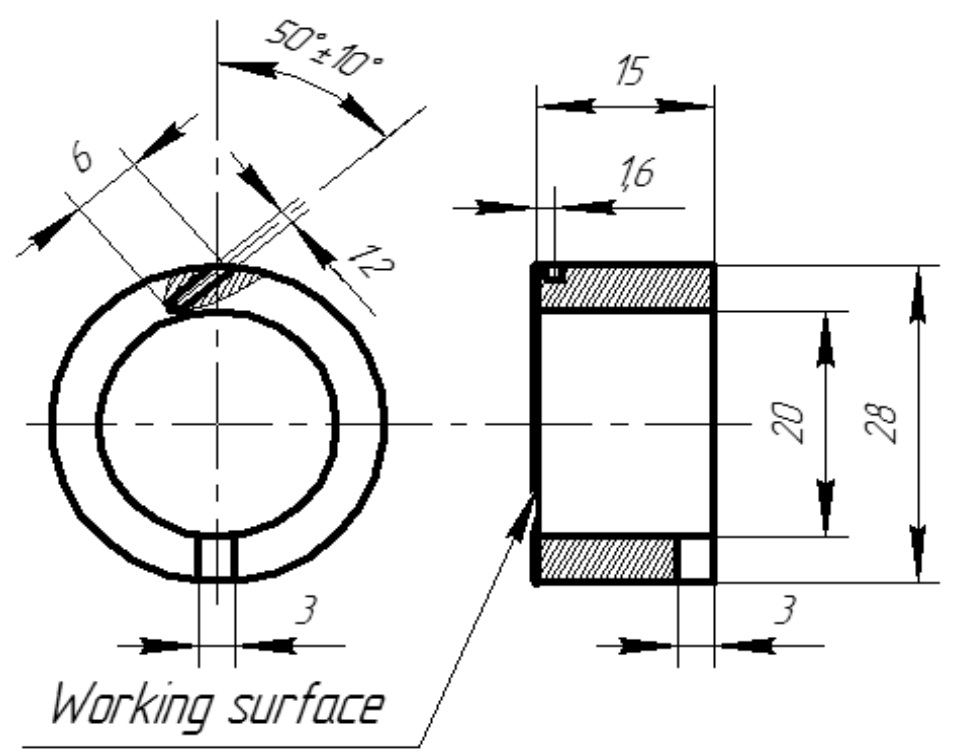

Fig. 2.12. Specimens for friction heat resistance tests

The coefficient of friction was determined as the fraction from the division of the friction force $\mathrm{F}$ into the total load $\mathrm{N}$ by the formula:

$$
f=\frac{F}{N} \text {. }
$$

The intensity of deterioration was determined by the formula:

$$
I_{h}=\frac{h}{L},
$$

where $\mathrm{h}$ - linear wear, $\mu \mathrm{m} ; \mathrm{L}$ - friction path, $\mu \mathrm{m}$.

Sclerometric investigations were carried out by scratching (drawing the grooves) of the surface with a diamond cone with an angle of $120^{\circ}$, while the device (Fig. 2.10) proposed in ${ }^{81,82}$ was used. The device consists

81 Прилад для склерометричних досліджень: пат. 70725 Україна. № U201113900; заявл. 25.06.11; опубл. 25.06.12, Бюл. № 12.

82 Присяжнюк П.М. Закономірності формування структури та властивостей карбідосталей на основі сталі Гадфільда : дис. ... канд. техн. наук : 05.02.01. Київ, 2014. 159 с. 
of a base 1 , on which the holder 2 of the sample 3 of the test shaft is installed and the drive of the movement 4 of the scrubbing system, which consists of a housing 5, on the horizontal part of which is a load node containing a vertically positioned rod 6 and weights 7 , and the holder 8 of the indenter 9 . The holder 8 is fixed to the housing 5 by a nut 10 . On the vertical part of the co-pillar 5, a flat elastic element 11, which at its second end interacts with the traction rod 12 of the drive 4 , is secured with one end as well as a cam mechanism consisting of a roller 13, which is mounted on an axis 14, fixed in the fork 15. The fork 15 is threaded part 16 secured to the groove 17 of base 1 with the possibility of vertical and horizontal displacement. Due to this displacement, the axis 14 of the roller 13 is placed perpendicularly to the direction of the indenter movement.

The roller 13 interacts with the flat plate 18 fixed hingedly on the bottom of the housing 5. The plate interacts with the adjusting screw 19 and the tension spring 20 fixed in the body 5. Both elements 19 and 20 allow the angle $\alpha$ of the interaction of the plate 18 with the roller 13 to be changed.

On the vertical part of the body 5, an induction displacement sensor 22 is installed on the vertical portion of the frame body 22 which, with its measuring rod 23, interacts with the flat spring element 11 . Several holes 21 ', 21, etc. can be made in the vertical part of the housing 5, etc. By installing the sensor 22 in one or the other hole can change the sensitivity and range of the deformation measurement of the flat spring element 11 , which is proportional to the force of scratching.

The sensor 22 is connected to the node of registration of the value of deformation, whose function is to amplify the signals and output the corresponding indicator for recording information about the magnitude of the tangential force of scratching.

The calculation of hardness in this method $\left(\mathrm{H}_{\mathrm{s}}\right)$ was carried out according to the formula in the paper ${ }^{83}$ :

$$
H_{s}=\frac{8 P}{\pi a^{2}}
$$

where $\mathrm{P}-$ load on the indenter, $\mathrm{a}-$ width of the groove.

83 Рацька Н.Б. Підвищення зносостійкості сплаву системи $\mathrm{Nb}$ - $\mathrm{Ti}$ термомодифузійним оксидуванням : дис. ... канд. техн. наук : 05.02.01. Львів, 2015. $140 \mathrm{c}$. 


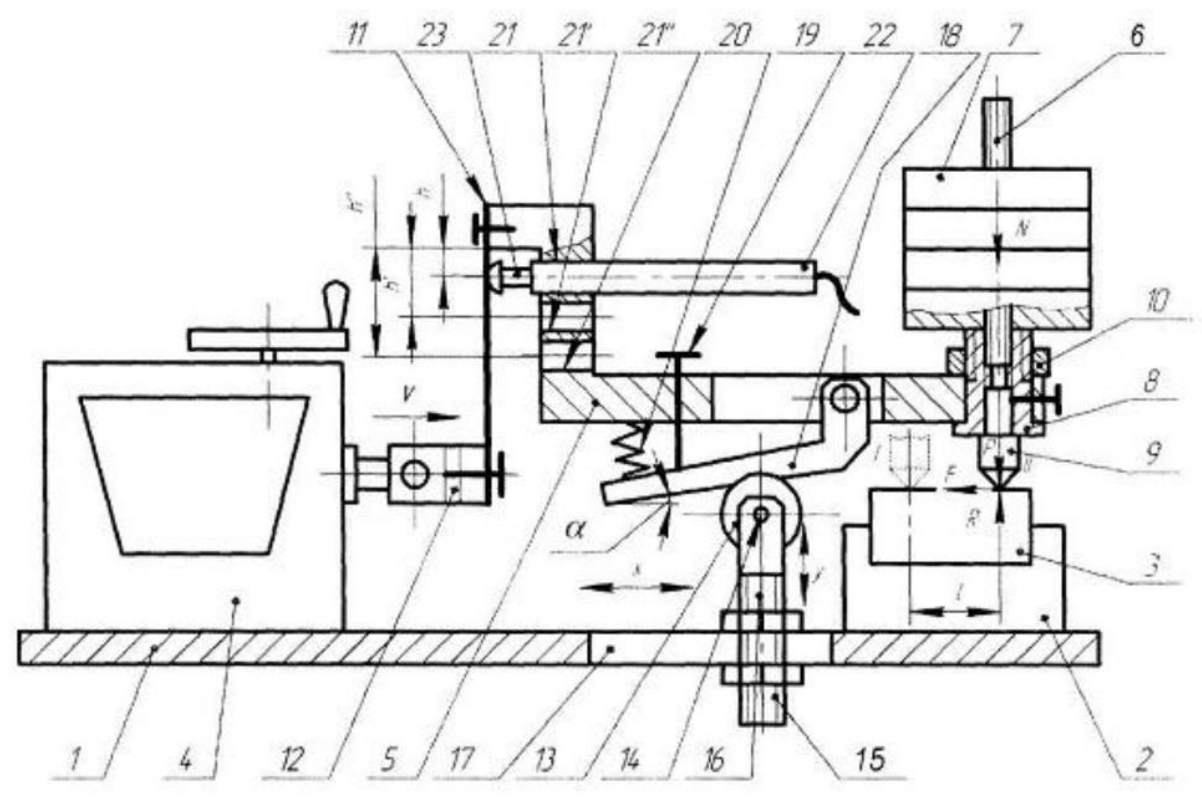

Fig. 2.13. Instrument for sclerometric investigations

The bench tests of performance characteristics of rings of mechanical seals with the purpose of determining their stability in conditions of dry friction that correspond to the stage of starting the pump with insufficient quantity or displacement of the working medium were carried out for pairs of ceramics - ceramics and ceramics - ceramics. The metal-ceramic ring 1 (Fig. 2.14) was fixed in the case 3, and the ceramic 4 was mounted on the intermediate sleeve, which was cut onto the shaft. The clamping of the rings was provided with a set of ten springs embedded in the sleeve 5 (Fig. 2.15).
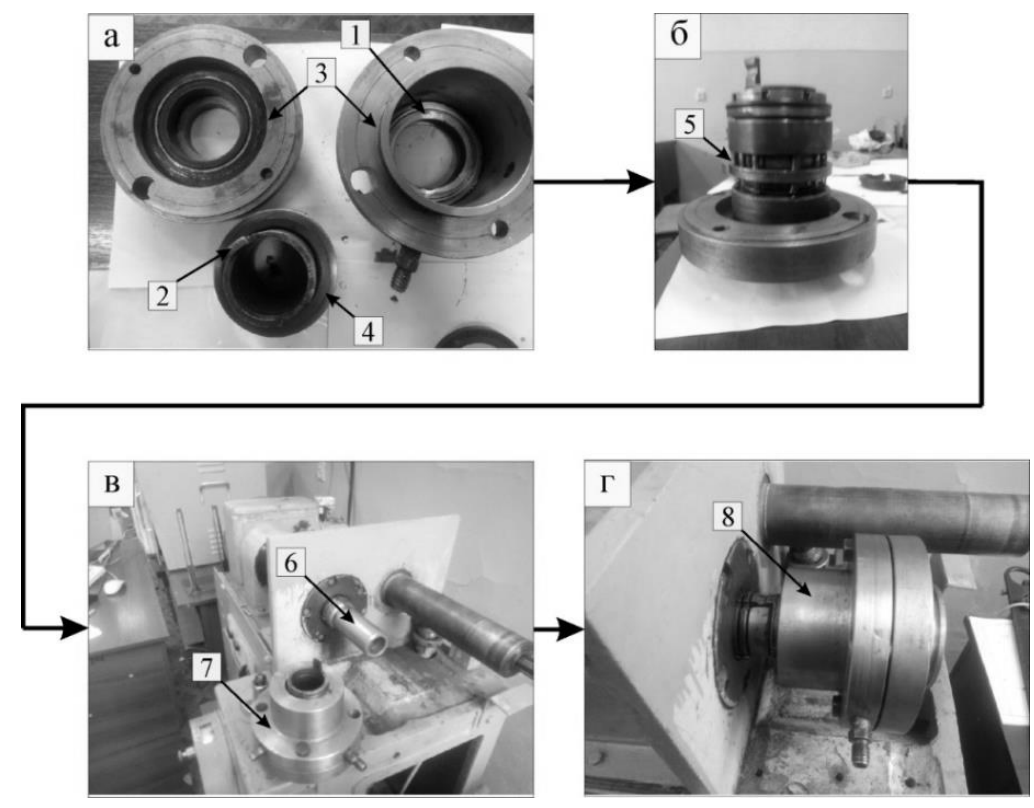

Fig. 2.14. Stages of the mechanical seal mounting on the test stand 
The assembled mechanical seal 1 (Fig. 2.15) was mounted on the shaft of the SMC2 machine. To determine the coefficients of friction, the shaft with mounted face seal was connected to the inductive friction torque sensor 3, which in turn was connected to an analog-to-digital converter (ADC). The temperature was measured using a thermocouple placed at a distance of $1 \mathrm{~mm}$ from the friction contact zone, which was also connected to the ADC 5.

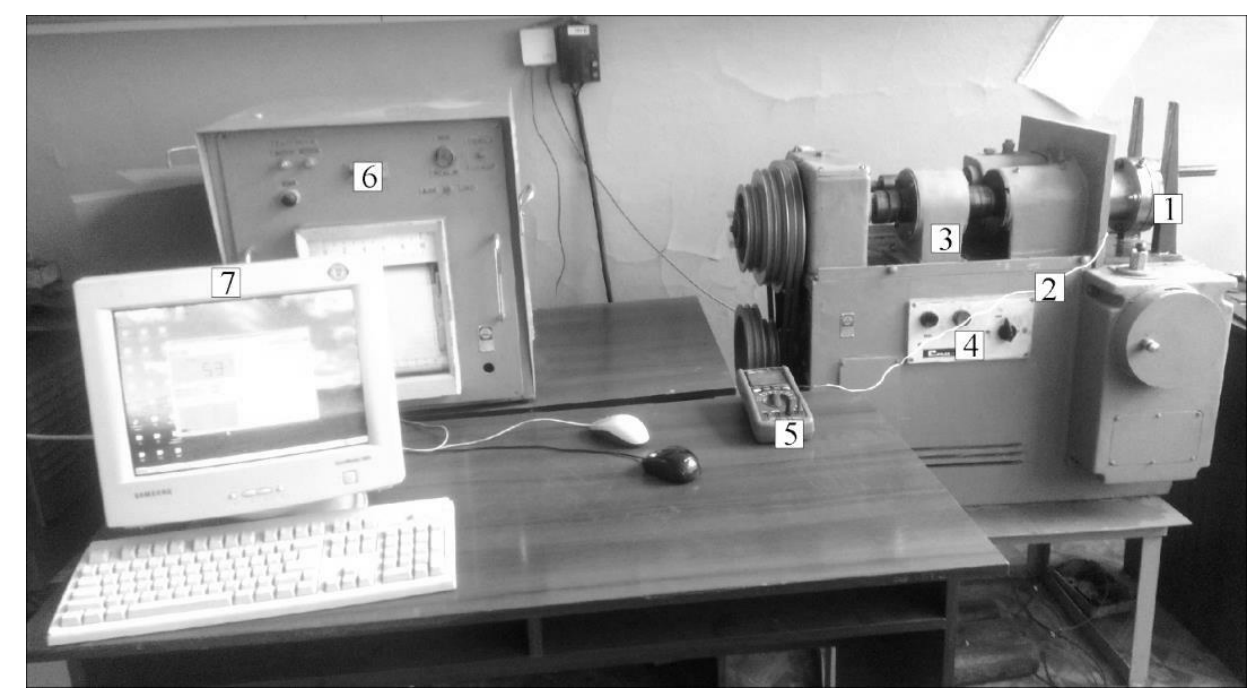

Fig. 2.15. Stand for research of rings of mechanical sealing devices:

1 - mechanical seal; 2 - thermocouple; 3 -friction torque sensor; 4 - rotating machine SMC-2; 5 - UT-78B multimeter with ADC; 6 - control unit of SMC-2; 7 - personal computer

The assessment of the wear resistance of the developed cermets was carried out under conditions of friction on the fixed abrasive. As a counter body (abrasive), an abrasive disc made of silicon carbide with a diameter of $300 \mathrm{~mm}$ and a thickness of $40 \mathrm{~mm}$ was used. The sliding velocity was $0.21 \mathrm{~m} / \mathrm{s}$, the friction path was $33 \mathrm{~m}$. The test was carried out on samples of a cylindrical shape with a diameter of $10 \mathrm{~mm}$ (samples for testing the wear resistance of cermets were obtained by soldering of tablets made from them to steel models). The standard in the research was the electrodes T-590 (JSC "Spetselektrod", Russia production) deposited on samples of a cylindrical form by the gas-lumene method. For comparative analysis of selected materials for welding with high content of $\mathrm{Cr}$ (> 20 wt.\%), Namely sormayt CA-1 (GOST 21449-75) and T-620 (manufactured Institute of Electric them. Paton, Ukraine). Relative wear resistance $(\varepsilon)$ determined by mass loss by weighing samples to an analytical balance with an accuracy of $\sim 1 \mathrm{mg}$. 


\section{Selection of rational technological parameters for obtaining rings of centrifugal oil and gas pumps from composites of $\mathrm{Cr}_{3} \mathrm{C}_{2}-\mathrm{Cu60Ni20Mn20} \mathrm{system}$}

\subsection{Basic parameters influencing the kinetics of infiltration of porous ceramic frames by melt}

Among the technologies that can be used for the manufacture of rings of mechanical seal of cermets with a binder on the basis of manganese cupronickel most rationally apply the method of furnace surfacing with the method of infiltration in view of its advantages over traditional methods, among which the main ones are:

- the profitability of technology, which allows the use of scarce materials with high physical and mechanical characteristics only for working surfaces;

- the possibility of using alloys for infiltration in the form of waste;

- simplicity of technology, which is ensured by the use of standard oven and turning equipment;

Equation (2.9) considering the action of gravity and Laplace's pressure (for the "effective radius" of the capillaries) takes the form ${ }^{84,85}$ :

$$
\frac{d h(t)}{d t}=\frac{k}{\Pi \mu}\left(\frac{\gamma \cos (\Theta)}{r_{e f} \Pi h(t)}-\rho g\right),
$$

where $\gamma$ is the surface energy of manganese molybdenum $\mathrm{mJ}$; $\mathrm{r}_{\mathrm{ef}}$ - effective radius of capillaries, $\mathrm{m} ; \Theta$ - contact angle of wetting, degrees; $\rho$ - specific gravity of melt, $\mathrm{N} / \mathrm{m}^{3}$.

The effective radius of the capillaries was calculated according to the data of according to the Karman formula:

$$
r_{e f}=\frac{d_{c h} \Pi}{6(1-\Pi)},
$$

where $d_{c h}$ is the average particle size of the porous frame.

The coefficient of permeability of the porous framework $(\mathrm{k})$, considering the above-mentioned data in $^{86}$, was calculated by the formula:

${ }^{84}$ Шіхаб Т.А., Криль Я.А., Парайко Ю.І. та ін. Кінетика просочування Сr3С2 марганцевим мельхіором у процесі отримання керметів. Фізика і хімія твердого тіла. Івано-Франківськ. 2015 . №16 (2). С. 408-412.

85 Scheidegger E. The physics of flow through porous media (3rd ed.) : monography. Toronto : University of Toronto Press, 1974. 353 p. 


$$
k=\frac{\Pi^{3}}{K_{k 0 z} S^{2}(1-\Pi)^{2}},
$$

where $\mathrm{K}_{\mathrm{koz}}$ is the Kozeni constant, which depends on the data on the form of capillaries, for the spherical form of particles its value is 5, and for the irregullar - 4,2. The specific surface of particles $S$ in this equation is the ratio of the particle's area to its volume. Considering the results of electron microscopic studies of fracture fractures of a porous carbide framework (Fig. 3.1), it was adopted: $\mathrm{K}_{\mathrm{koz}}=5 ; \mathrm{S}=6 / \mathrm{d}_{\mathrm{ch}}\left(\mathrm{d}_{\mathrm{ch}}=6 \mu \mathrm{m}\right)$.

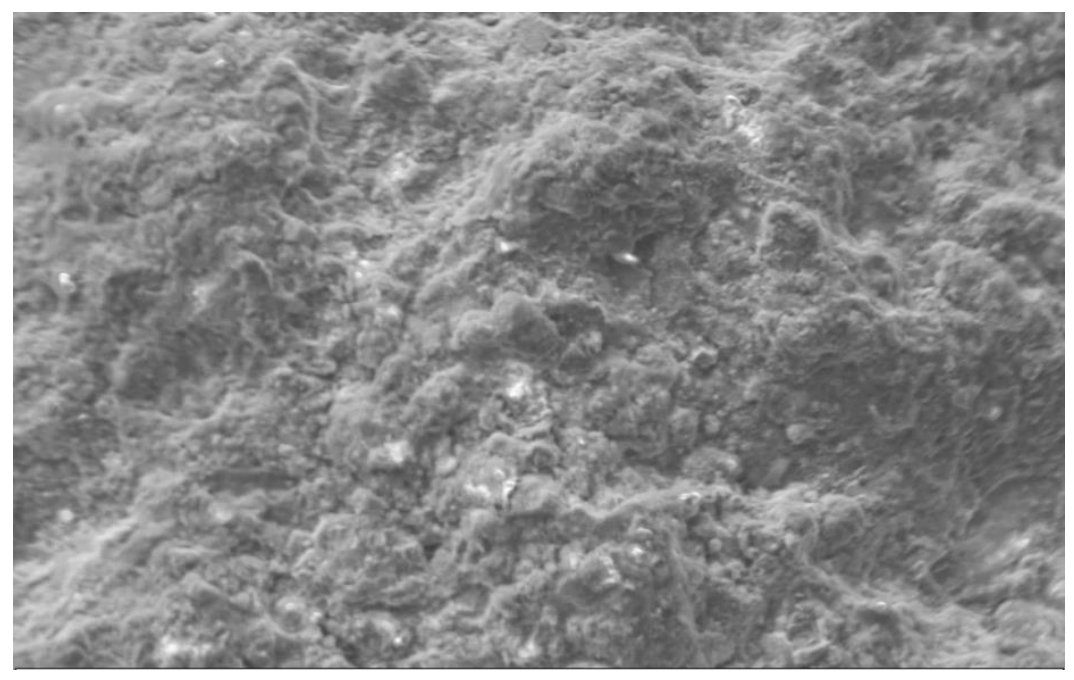

Fig. 3.1. Morphology of fractograms of fracture of porous frame $\mathrm{Cr}_{3} \mathrm{C}_{2}(\times 2000)$

\subsection{Calculation of the temperature dependence of the surface tension of manganese cupronickel}

To correctly calculate the surface tension, Butler's theory ${ }^{87}$ was used, according to which the surface tension is a function of the physical properties of the components and the thermodynamic parameters of their interaction. In this case, the surface monoatomic layer is considered as an independent phase, which is in equilibrium with the rest of the melt volume. For a system consisting of $\mathrm{n}$ components, the surface tension equation $\left(\gamma_{\mathrm{n}}\right)$ can be written as:

${ }^{86}$ Kozeny J. Ueber kapillare Leitung des Wassers im Boden. Sitzungsber Akad. Wiss. Wien. 1927. №136(2a). PP. 271-306.

${ }^{87}$ Butler J.A.V. Thermodynamics of the surfaces of solutions. Proc. Roy. Soc. London, Ser A. London. 1932. № 135. PP. 348-375. 


$$
\gamma_{n}(T)=\gamma_{i}+\frac{R T}{A_{i}} \ln \left(\frac{c_{i}^{S}}{c_{i}^{B}}\right)+\frac{1}{A_{i}}\left\{{ }^{E} G_{i}^{S}\left(T, c_{i}^{S}\right)-{ }^{E} G_{i}^{B}\left(T, c_{i}^{B}\right)\right\},(i=1,2 \ldots n),
$$

where $\gamma_{i}$ is the surface tension of the $\mathrm{i}$-th component, $\mathrm{J} / \mathrm{m}^{2} ; \mathrm{R}$ - universal gas constant, $\mathrm{J} / \mathrm{mol} \cdot \mathrm{K} ; \mathrm{A}_{\mathrm{i}}$ - surface area of the monoatomic layer of the liquid component, $\mathrm{m}^{2} ; \mathrm{c}_{\mathrm{i}}{ }^{\mathrm{S}}$ and $\mathrm{c}_{\mathrm{i}}{ }^{\mathrm{B}}$-surface and volume concentration of components, respectively, at. particles; ${ }^{\mathrm{E}} \mathrm{G}_{\mathrm{i}}{ }^{\mathrm{S}}$ and ${ }^{\mathrm{E}} \mathrm{G}_{\mathrm{i}}^{\mathrm{B}}$ are the surface and volume partial excess free energy of the component, respectively, $\mathrm{J} / \mathrm{mol}$.

The value of $\mathrm{A}_{\mathrm{i}}$ according to the data of work ${ }^{88}$ is calculated by the formula:

$$
A_{i}=1,091 N^{\frac{1}{3}} V_{i}^{\frac{2}{3}}
$$

where $\mathrm{N}$ is Avogadro's number; $\mathrm{V}_{\mathrm{i}}$ - molar volume of pure component, $\mathrm{m}^{3}$.

The value ${ }^{\mathrm{E}} \mathrm{G}_{\mathrm{i}}^{\mathrm{B}}$ is determined by the excess energy of the system $\left({ }^{\mathrm{E}} \mathrm{G}^{\mathrm{B}}\right)$ by the equation:

$$
{ }^{E} G_{i}^{B}\left(T, c_{i}^{B}\right)={ }^{E} G^{B}+\left(1-c_{i}^{B}\right) \frac{\partial^{E} G^{B}}{\partial c_{i}},
$$

in turn, the redundant energy of the system in the form of RedlichKister's polynomials ${ }^{89}$ is determined by the formula:

$$
{ }^{E} G^{B}=\sum_{i=1}^{2} \sum_{j>1}^{3} c_{i}^{B} c_{j}^{B} \sum_{v=0}^{1}{ }^{v} L_{i j}(T)\left(c_{i}-c_{j}\right)^{v},
$$

where $\mathrm{L}_{\mathrm{ij}}$-interaction parameters.

With the known value of ${ }^{\mathrm{E}} \mathrm{G}_{\mathrm{i}}{ }^{\mathrm{B}}$, the value of ${ }^{\mathrm{E}} \mathrm{G}_{\mathrm{i}}{ }^{\mathrm{S}}$ authors suggestdetermine the formula:

$$
{ }^{E} G^{S} \approx 0,83^{E} G^{B} .
$$

For the ternary system $\mathrm{Cu}-\mathrm{Ni}-\mathrm{Mn}$ equation (3.1) will look like:

${ }^{88}$ Zhongnan Guo, Michael Hindler, Wenxia Yuan, Adolf Mikula The density and surface tension of $\mathrm{In}-\mathrm{Sn}$ and $\mathrm{Cu}-\mathrm{In}-\mathrm{Sn}$ alloys. Monatshefte für Chemie Chemical Monthly. 2011. Vol. 142, № 6. PP. 579-584.

89 Redlich Otto, Kister A. T. Algebraic representation of thermodynamic properties and the classification of solutions. Ind. Eng. Chem. 1948. Vol.40, № 2. PP. 345-348. 


$$
\begin{aligned}
\gamma_{C u N i M n}(T) & =\gamma_{C u}+\frac{R T}{A_{C u}} \ln \left(\frac{1-c_{N i}^{S}-c_{M n}^{S}}{1-c_{N i}^{B}-c_{M n}^{B}}\right)+\frac{1}{A_{C u}}\left\{{ }^{E} G_{C u}^{S}\left(T, c_{N i}^{S}, c_{M n}^{S}\right)-{ }^{E} G_{C u}^{B}\left(T, c_{N i}^{B}, c_{M n}^{B}\right)\right\} \\
& =\gamma_{N i}+\frac{R T}{A_{N i}} \ln \left(\frac{c_{N i}^{S}}{c_{N i}^{B}}\right)+\frac{1}{A_{N i}}\left\{{ }^{E} G_{N i}^{S}\left(T, c_{N i}^{S}, c_{M n}^{S}\right)-{ }^{E} G_{N i}^{B}\left(T, c_{N i}^{B}, c_{M n}^{B}\right)\right\} \\
& =\gamma_{M n}+\frac{R T}{A_{M n}} \ln \left(\frac{c_{M n}^{S}}{c_{M n}^{B}}\right)+\frac{1}{A_{M n}}\left\{{ }^{E} G_{M n}^{S}\left(T, c_{N i}^{S}, c_{M n}^{S}\right)-{ }^{E} G_{M n}^{B}\left(T, c_{N i}^{B}, c_{M n}^{B}\right)\right\}
\end{aligned}
$$

The temperature dependences of the surface tension for pure $\mathrm{Cu}, \mathrm{Ni}$ and $\mathrm{Mn}$ according to work ${ }^{90}$ are, $\mathrm{mJ} / \mathrm{m}^{2}$ :

$$
\begin{aligned}
& \gamma_{C u}=1355-0,19(T-1358) \\
& \gamma_{N i}=1796-0,35(T-1728) ; \\
& \gamma_{M n}=1100-0,35(T-1519) .
\end{aligned}
$$

The partial Gibbs superfluous energy of the components in the melt can be represented in accordance with ${ }^{91}$ in the form:

$$
\begin{aligned}
& { }^{E} G_{C u}^{B}\left(T, c_{M n}^{B}, c_{N i}^{B}\right)={ }^{E} G^{B}-c_{M n}^{B} \frac{\partial^{E} G^{B}}{\partial c_{M n}}-c_{N i}^{B} \frac{\partial^{E} G^{B}}{\partial c_{N i}} \\
& { }^{E} G_{M n}^{B}\left(T, c_{M n}^{B}, c_{N i}^{B}\right)={ }^{E} G^{B}+\left(1-c_{M n}^{B}\right) \frac{\partial^{E} G^{B}}{\partial c_{M n}}-c_{N i}^{B} \frac{\partial^{E} G^{B}}{\partial c_{N i}}, \\
& { }^{E} G_{N i}^{B}\left(T, c_{M n}^{B}, c_{N i}^{B}\right)={ }^{E} G^{B}-c_{M n}^{B} \frac{\partial^{E} G^{B}}{\partial c_{M n}}+\left(1-c_{N i}^{B}\right) \frac{\partial^{E} G^{B}}{\partial c_{N i}}
\end{aligned}
$$

where ${ }^{\mathrm{E}} \mathrm{G}^{\mathrm{B}}$ for the system $\mathrm{Cu}-\mathrm{Ni}-\mathrm{Mn}$ after substitution takes the form:

$$
{ }^{E} G^{B}=c_{C u}^{B} c_{N i}^{B} L_{C u: N i}+c_{C u}^{B} c_{M n}^{B} L_{C u: M n}+c_{M n}^{B} c_{N i}^{B} L_{M n: N i}+c_{C u}^{B} c_{N i}^{B} c_{M n}^{B} L_{C u: N i: M n} .
$$

The temperature dependences of the interaction parameters (L) according to the work ${ }^{92}$ have the form:

${ }^{90} \mathrm{Lu} \mathrm{H}$., Jiang M. Tension and Its Temperature Coefficient for Liquid Metals. J. Phys. Chem. B. 2005. Vol.109. PP. 15463-15468.

91 Brillo J., Plevachuk Y. Egry I. Surface tension of liquid Al-Cu-Ag ternary alloys. Journal of Materials Science. 2010. Vol. 45, № 19. PP. 5150-5157.

Miettinen J. Thermodynamic description of the $\mathrm{Cu}-\mathrm{Mn}-\mathrm{Ni}$ system at the $\mathrm{Cu}-\mathrm{Ni}$ side. Computer Coupling of Phase Diagrams and Thermochemistry. 2003. № 27. PP. 147-152 


$$
\begin{gathered}
L_{C u: N i}=(11760+1,084 T)+(-1672)\left(c_{C u}^{B}-c_{N i}^{B}\right) ; \\
L_{C u: M n}=(1800-2,28 T)+(-6500-2,91 T)\left(c_{C u}^{B}-c_{M n}^{B}\right) ; \\
L_{N i: M n}=(-85853+22,715 T)+(-1620+4,902 T)\left(c_{N i}^{B}-c_{M n}^{B}\right) ; \\
L_{C u: N i: M n}=(-7000) c_{C u}^{B}+(25000-50 T) c_{N i}^{B}+(-111000+50 T) c_{M n}^{B} .
\end{gathered}
$$

The surface area of the monoatomic component layers after the substitution of the values in equation (3.5) will be:

$$
\begin{aligned}
& A_{C u}=1,091\left(6 \cdot 10^{23}\right)^{\frac{1}{3}}\left(7,1 \cdot 10^{-6}\right)^{\frac{2}{3}} ; \\
& A_{N i}=1,091\left(6 \cdot 10^{23}\right)^{\frac{1}{3}}\left(6,5 \cdot 10^{-6}\right)^{\frac{2}{3}} \\
& A_{M n}=1,091\left(6 \cdot 10^{23}\right)^{\frac{1}{3}}\left(7,1 \cdot 10^{-6}\right)^{\frac{2}{3}} .
\end{aligned}
$$

For manganese cupronickel, the composition in atomic particles was taken as follows: $c_{c u}^{B}=0.57259 ; c_{N i}^{B}=0.20664 ; c_{y_{n}}^{B}=0.22077$. Thus, after the substitution of the values in equation (3.11-3.13) and equation (3.9), a system of equations with two unknowns was obtained and the solution of which at a given temperature of $\mathrm{T}$ allowed the determination of the temperature dependence of the surface tension. The values found in the temperature range corresponding to the technological regimes of the manufacture of rings of end sealers were compared with the experimental data given in the paper ${ }^{93}$. The results of calculations (Fig. 3.2) (94 $^{94}$ show that the calculated values of the surface tension with high accuracy (deviation not exceeding $1 \%$ ) reproduce the results of experimental research. The temperature dependence of the surface tension of the $\mathrm{Cu}-20 \mathrm{Ni}-20 \mathrm{Mn}$ alloy is described with high accuracy (the value of the corrected determination coefficient is equal to 0.99987 ) by the equation, $\mathrm{mJ} / \mathrm{m}^{2}$ :

$$
\gamma(T)_{\text {Cu60Ni20Mn20 }}=1384,5-0,1735(T-1323) .
$$

${ }^{93}$ Myshko Yu.D., Klibus A.V., Gapchenko M.N., Ishchuk N.Ya. Wetting of some hard alloys by Melchior MNMts20-20. Soviet Powder Metallurgy and Metal Ceramics. 1974. Vol. 13, № 9. PP. 731-734.

${ }^{94}$ Prysyazhnyuk, P., Lutsak, D., Vasylyk, A., Thaer S, M. Burda et al. Calculation of surface tension and its temperature dependence for liquid $\mathrm{Cu}-20 \mathrm{Ni}-20 \mathrm{Mn}$ alloy. Metallurgical and Mining Industry. 2015. № 12, P. 346-350. 
Thus, after substituting the value of the infiltration temperature, in the equation (3.15), the surface tension of the melt of manganese molybdenum will be $1358 \mathrm{~mJ} / \mathrm{m}^{2}$.

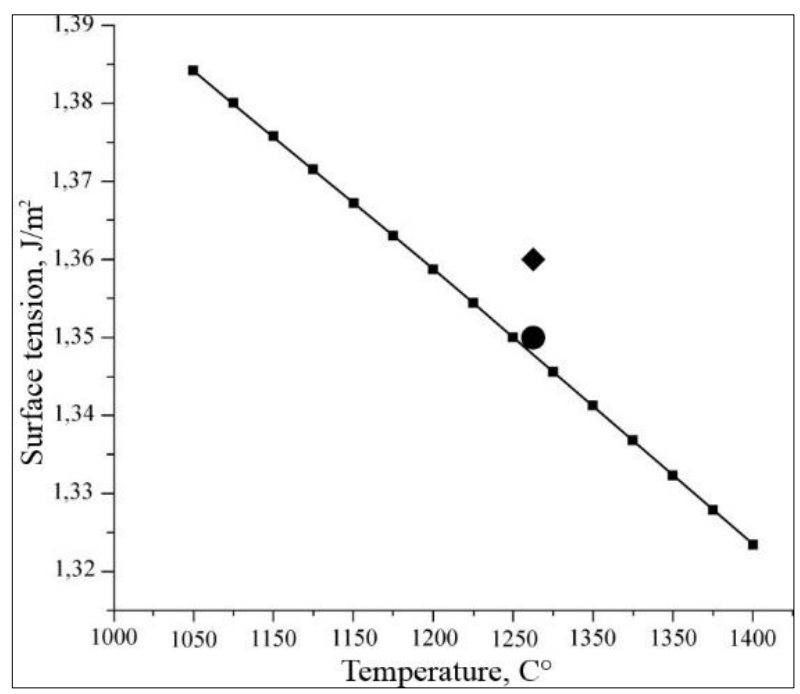

Fig. 3.2. Temperature dependence of surface tension of manganese silicon $\mathrm{Cu}-20 \mathrm{Ni}-20 \mathrm{Mn}$ :

- calculation; - -values obtained when the capillary is charged at 4, 10 and $16 \mathrm{~mm}^{93} ;-$ averaged result according to ${ }^{93}$

It also should be noted that according to the results of calculations, the distribution of elements in volume and on the surface is significantly different, especially in the concentration of manganese (Fig. 3.3). which in the surface layer is practically 1.4 times higher than in the main volume, this contributes to the intensification of the infiltration process and the formation of the structure of the composite material (coating).

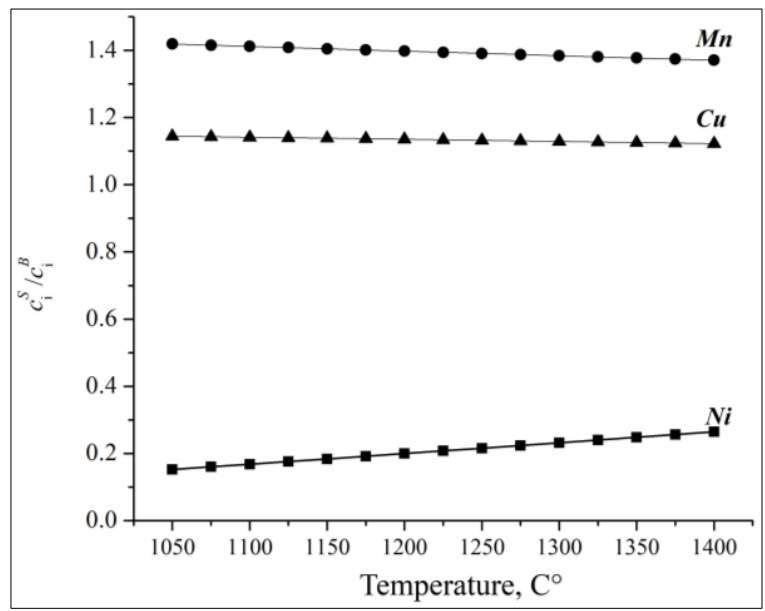

Fig. 3.3. Temperature dependence of the ratio of components of the $\mathrm{Cu}-20 \mathrm{Ni}-20 \mathrm{Mn}$ alloy on the surface and in volume 


\subsection{Determination of the kinetics of infiltration of the porous frame $\mathrm{Cr}_{3} \mathrm{C}_{2}$ with MNMTs alloy}

A prerequisite for obtaining materials by infiltration is to provide wettability in the porous body-melt system. The susceptibility of chromium carbide to the $\mathrm{Cu}-\mathrm{Ni}-\mathrm{Mn}$ alloy was investigated by the lying drop method on sintered samples of chromium carbide cylindrical in diameter of $30 \mathrm{~mm}$, porosity of $8-10 \%$ in a vacuum environment at a temperature of $1150^{\circ} \mathrm{C}$. Alloys for the study of wettability were prepared by fusing in a vacuum of pure copper and silicon of the brand MNMTs 60-20-20 in different proportions, the duration of exposure at a wettability temperature was 15 minutes. As can be seen from the concentration dependence of the contact angle wetting the carbide of chromium is poorly wetted by pure copper (the contact angle is $50^{\circ}$ ), but with an increase in $\mathrm{Ni}$ and $\mathrm{Mn}$ there is a tendency to decrease it (Fig. 3.4). Full wettability (the contact angle is $0^{\circ}$ ) is achieved with a total content of $\mathrm{Ni}$ and $\mathrm{Mn}$ of $30 \%$ by weight and with further increase in the amount of $\mathrm{Ni}$ and $\mathrm{Mn}$ does not change. This creates the preconditions for obtaining the materials of the $\mathrm{Cr}_{3} \mathrm{C}_{2}$-Cu60Ni20Mn20 system by infiltration.

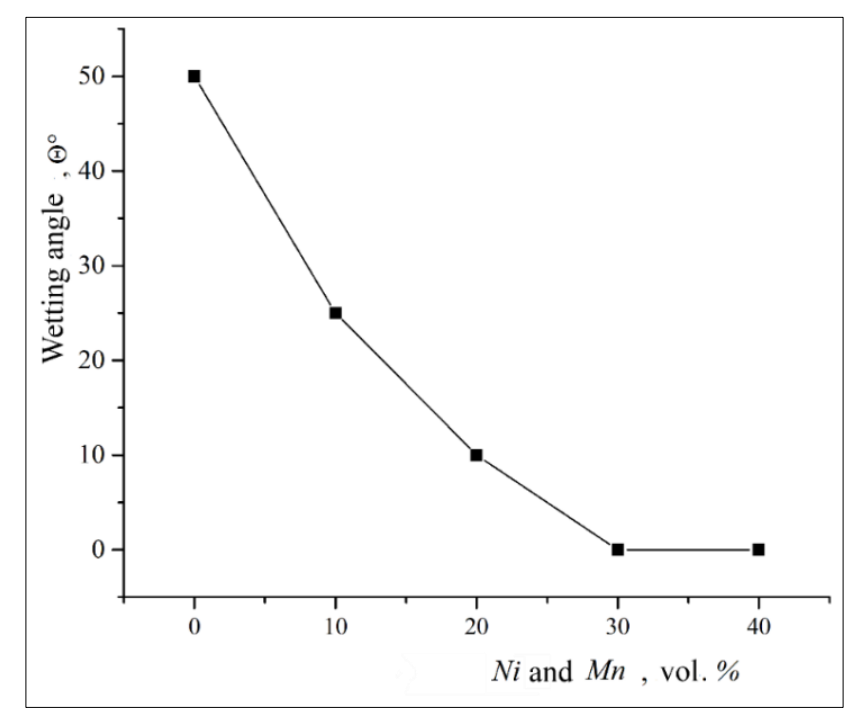

Fig. 3.4. Concentration dependence of the contact angle of wetting $\mathrm{Cr}_{3} \mathrm{C}_{2} \mathrm{Cu}-\mathrm{Ni}$-Mn alloy at a temperature of $1150{ }^{\circ} \mathrm{C}$ from the total content of $\mathrm{Ni}$ and $\mathrm{Mn}$

The temperature dependences of the dynamic viscosity of the melt and its specific gravity, calculated using the JMatPro program ${ }^{95}$ (database -

95 JMatPro practical software for materials properties URL: http:// www.sentesoftware. co.uk/jmatpro.aspx (дата звернення: 15.12.2018). 
Nickel base superalloy) are shown in Fig. 3.5. As can be seen from the figure, the point of the liquidus of the MNMTS alloy is $1038^{\circ} \mathrm{C}$, and its viscosity and density at the infiltration temperature are $4.35 \mathrm{mPa} \cdot \mathrm{s}$ and $74161 \mathrm{~N} / \mathrm{m}^{3}$, respectively.

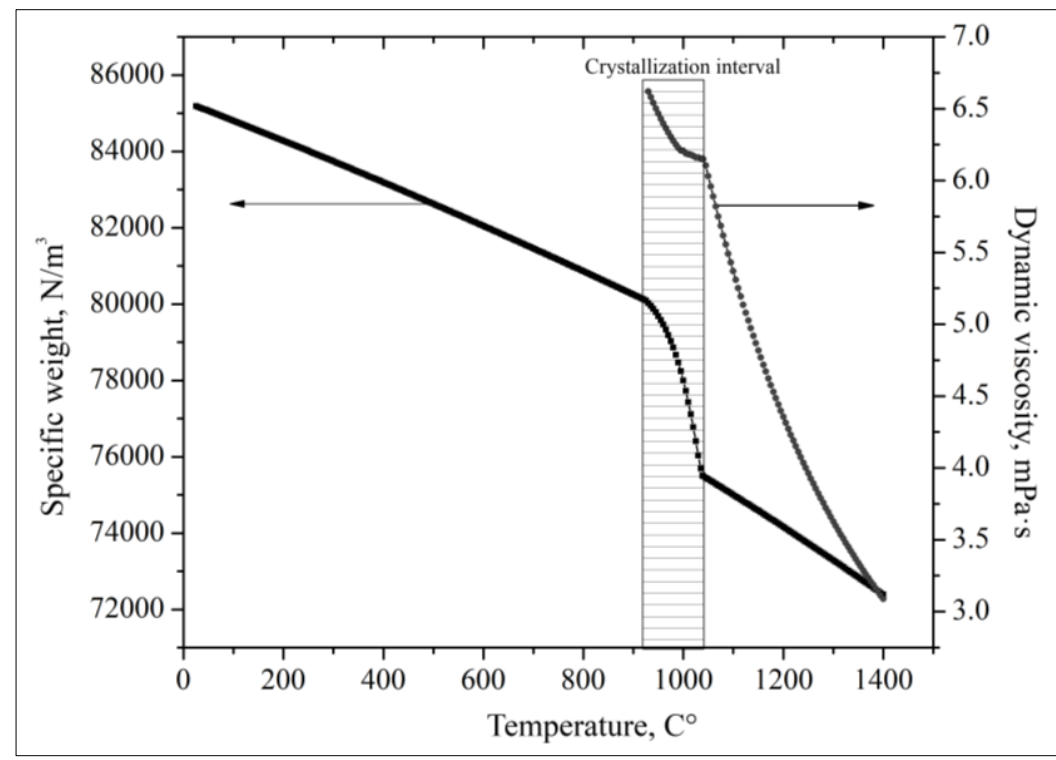

Fig. 3.5. The temperature dependence of the dynamic viscosity and the density of the MNMTs alloy

After substituting the values (3.2) and (3.3) into equation (3.1), it has the form:

$$
\frac{d h(t)}{d t}=-\frac{1}{36}\left(\frac{\Pi d_{u}\left(\rho g \Pi d_{u} h(t)+6 \gamma(-1+\Pi)\right)}{\mu K_{k o z}(-1+\Pi)^{2} h(t)}\right),
$$

Equation (3.16) is transcendent, so its solution to $\mathrm{h}(\mathrm{t})$ for boundary conditions $h(0)=0$ was carried out using W-Lambert function $(\text { LambertW })^{96,97}$ embedded in the computer algebra Maple system. As a result, an equation was obtained that describes the depth of the infiltrated layer, depending on the time, the characteristics of the morphology of the porous framework and the properties of the melt:

${ }^{96}$ Шіхаб Т.А., Криль Я.А., Парайко Ю.І. та ін. Кінетика просочування Сr3С2 марганцевим мельхіором у процесі отримання керметів. Фізика і хімія твердого тіла. Івано- Франківськ. 2015. № 16 (2). С. 408-412.

97 Дубинов А.Е., Дубинова И.Д., Сайков С.К. W-функция Ламберта и ее применение в математических задачах физики. Самаров : ФГУП «РФЯЦ-ВНИИЭФ», 2006. 160 с. 


$$
h(t)=-\frac{6 \gamma\left(\text { Lambert } W\left(-e^{\frac{1}{216} \frac{-216 \mu K_{k 0} \gamma(-1+\Pi)^{3}+t \Pi^{3} d_{\psi}^{3} \rho^{2} g^{2}}{\mu K_{k 0} \gamma(-1+\Pi)^{3}}}\right)+1\right)(-1+\Pi)}{g \rho d_{\psi} \Pi} .
$$

Calculated by formula (3.17) the depth of the infiltrated layer was compared with experimental data. The results (Fig. 3.6, a) show that the growth of the depth of the infiltrated layer, depending on the time, is described by a curve whose shape is close to the parabolic. It describes experimental data with sufficiently high accuracy. However, with an increase in the length of the process of rejection of experimental and calculated values increases. This is probably due to a change in the geometry of the capillaries as a result of an increase in the contact duration of the melt with the carbide phase, which leads to its recrystallization through the liquid phase. The depth of the infiltrated layer calculated according to equation (3.17) depending on the porosity is described by the dependence close to the linear (Fig. 3.6, b), with the increase of porosity, the deviation of the experimental data from the calculated decreases. This is due to the presence of closed pores in the intergranular space, which also decreases with a decrease in the volumetric content of the carbide phase. Using equation (3.17), we can make a rational choice of infiltration modes for the production of composite materials, in which, when dry friction occurs, the formation of protective antifriction surface layers takes place.

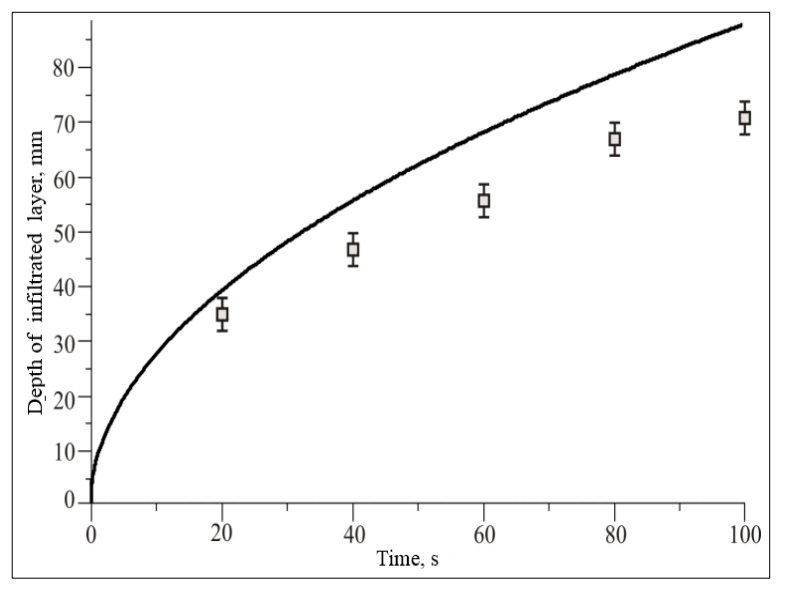

a

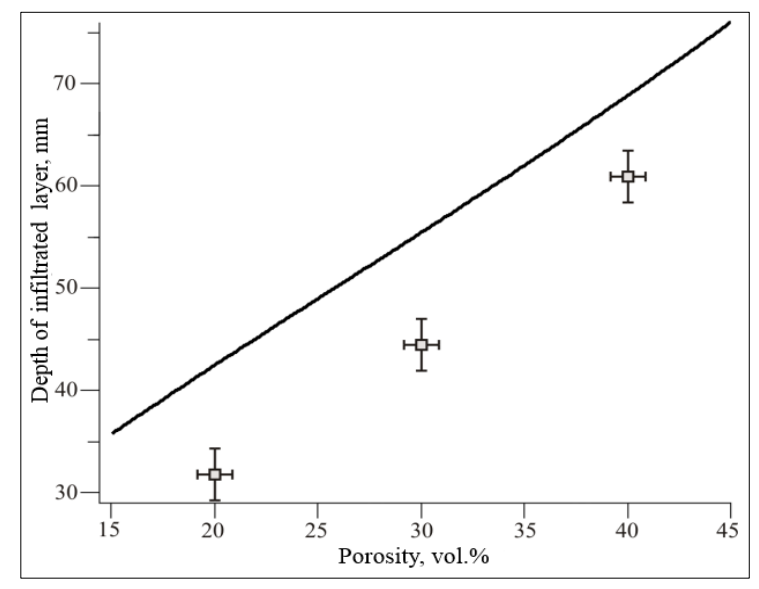

б

Fig. 3.6. Dependence of the depth of the infiltrated layer of the $\mathrm{Cr}_{3} \mathrm{C}_{2}$ frame with the alloy of the MNMTs from time ( $P=40 \%$ by volume $)$ (a) and from the porosity $(t=60 \mathrm{c})-(\mathrm{b})$ 
Using equation (3.17) one can also predict the depth of the infiltrated layer depending on the average particle size of which the porous frame is composed. Calculations show that the growth kinetics of the depth of the infiltrated layer, depending on the average particle size, is described by the curve with the maximum, (fig. 3.7) which for the system $\mathrm{Cr}_{3} \mathrm{C}_{2}-$ MNMts falls on the size of $\sim 60$ microns. The presence of a maximum in the curves is due to the fact that two "competing" factors exist in the process of infiltration, namely: the Laplac pressure, which decreases with increasing particle size and the permeability coefficient, which increases and the gravitational component.

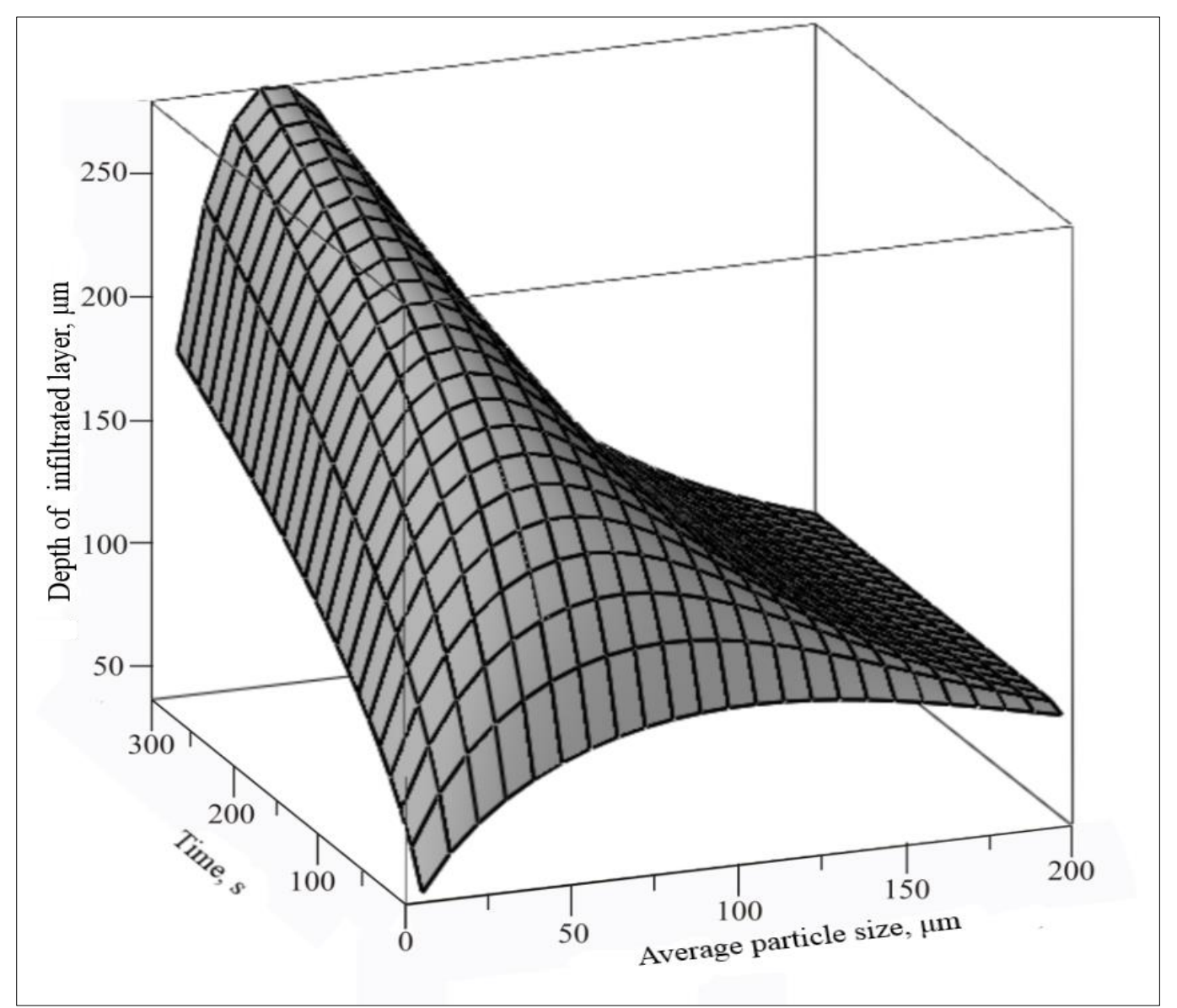

Fig. 3.7. Dependence of the kinetics of porous infiltration ( $P=40 \%$ by volume) of $\mathrm{Cr}_{3} \mathrm{C}_{2}$ frame with $\mathrm{MHMTs}$ alloy from the average particle size of the carbide phase

Thus, for each specific "bottom-up" infiltration condition, there is an average particle size, in which the superposition of the action of gravity and the Laplace pressure leads to the presence of a maximum of the depth of the infiltrated layer at a given process length. 


\section{Modeling of the heat transfer during running mechanical seals with seal faces of $\mathrm{Cr}_{3} \mathrm{C}_{2}-\mathrm{Cu} 60 \mathrm{Ni20Mn20}$ composites under dry friction conditions}

\subsection{Microstructure and phase composition of $\mathrm{Cr}_{3} \mathrm{C}_{2}-$ Cu60Ni20Mn20 composites}

The results of the microscopic studies required to create a material of the material show that the $\mathrm{Cr}_{3} \mathrm{C}_{2}$ starting powder is a conglomerate of particles of various sizes with a developed surface, which are characterized by the irregular shape (Fig. 4.1, a). After infiltration with a melt of manganese cupronickel in the (Fig 4.1, b), it can be seen that the main structural components of the resulting $\mathrm{Cr}_{3} \mathrm{C}_{2}-\mathrm{Cu} 60 \mathrm{Ni} 20 \mathrm{Mn} 20$ composite are three phases that differ in contrast and, accordingly, in density. During the point spectral analysis (Table 4.1), it was found that the central regions of the darkest phase (spectrum 1, Fig. 4.1, b) contain $\mathrm{Cr}$ and $\mathrm{C}$ in the ratio similar to the $\mathrm{Cr}_{3} \mathrm{C}_{2}$ carbide, whose morphology of the particles is substantially different from the raw material. The ratio of metal components $(\mathrm{Me})$ and $\mathrm{C}$ in the gray phase (spectrum 2, Fig. $4.1, \mathrm{~b}$ ) is closest to the $\mathrm{Me}_{7} \mathrm{C}_{3}$ compound, while it contains a significant amount of dissolved $\mathrm{Mn}$, as well as traces of $\mathrm{Ni}$ and Fe. Along with this, the alloy bonds (spectrum 3, Fig. 4.1, b) are substantially depleted by $\mathrm{Mn}$ and enriched with $\mathrm{Cr}$ and $\mathrm{C}$. Consequently, when the infiltration is carried out, an intense redistribution of elements results in the appearance of a new phase $\left((\mathrm{Cr}, \mathrm{Mn})_{7} \mathrm{C}_{3}\right)$ and a solid solution based on copper $(\mathrm{Cu}(\mathrm{Ni}, \mathrm{Mn}, \mathrm{Cr})){ }^{98}$
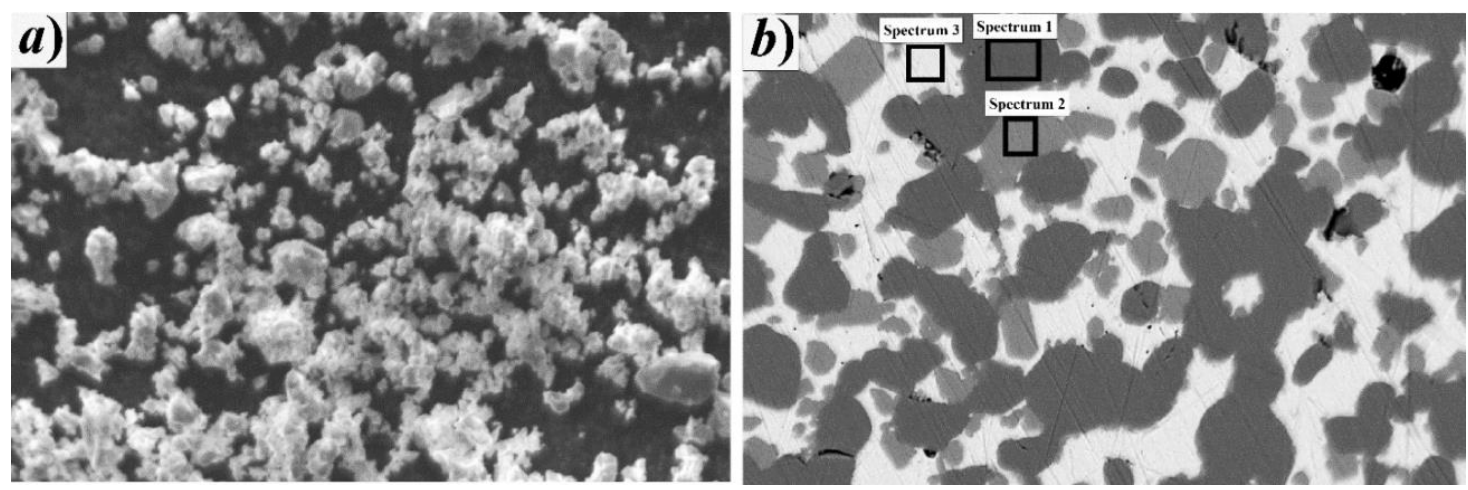

Fig. 4.1. The morphology of the $\mathrm{Cr}_{3} \mathrm{C}_{2}$ (a) $(\times 1000)$ powder output particles and the $\mathrm{Cr}_{3} \mathrm{C}_{2-} \mathrm{Cu} 60 \mathrm{Ni20Mn} 20(\times 1000)$ composite structure (b)

${ }^{98}$ Шлапак Л. С. Шіхаб Т., Присяжнюк П. М., Яремій І. П. Формування структури кермету на основі карбіду хрому 3 мідно-нікелево-маргановою зв'язкою. Металлофизика и новейшие технологии. Київ. 2016. № 38(7). С. 969-980. 
Table 4.1

Results of spectral analysis of the chemical composition of cermet $\mathrm{Cr}_{3} \mathrm{C}_{2}-\mathrm{Cu} 60 \mathrm{Ni20Mn20}$

\begin{tabular}{|c|c|c|c|c|c|c|c|}
\hline \multirow{2}{*}{ Spectrum } & \multicolumn{7}{|c|}{ Elemental composition, mass \% } \\
\cline { 2 - 8 } & $C r$ & $C$ & $C u$ & $M n$ & $N i$ & $F e$ & $S i$ \\
\hline 1 & 86.14 & 13.86 & - & - & - & - & - \\
\hline 2 & 79.70 & 9.83 & - & 6.39 & 2.30 & 1.77 & - \\
\hline 3 & 1.77 & 3.44 & 60.44 & 12.84 & 20.52 & 0.66 & 0.33 \\
\hline
\end{tabular}

The comparative analysis of the distribution of the size of the particles of the carbide chromium in the structure of the cermet in size (d) (Fig. 4.2) after approximating the lognormal distribution law shows that their average size is 3.7 and $5.6 \mu \mathrm{m}$, respectively (Fig. 4.2, a). Given that the carbide of chromium in the melt of pure copper is practically insoluble, this kind of grain growth is due to increasing in its equilibrium solubility in the melt due to the presence of Mn and Ni. In contrast to the initial state in the structure of the obtained cermet, the particles of the ceramic phase are observed in the form of grains mostly of round-shaped shape, while they occur both in the form of individual grains and in the form of fragments with a frame structure. Thus, the Cu60Ni20Mn20 melt in the interaction with $\mathrm{Cr}_{3} \mathrm{C}_{2}$ provides for the process of structuring by the dissolution-precipitation mechanism, in which the most dispersed $\mathrm{Cr}_{3} \mathrm{C}_{2}$ particles dissolve in the melt and crystallize on grains of larger sizes, while providing them with the acquisition of their equally important shape and size. The carbide phase formed by infiltration in the form of disperse inclusions with an average size of $\sim 1.7 \mu \mathrm{m}$, which are uniformly located in a bundle with an average value of the layers of $\sim 3.6 \mu \mathrm{m}$ (Fig. 4.2, b).

The results of the X-ray diffraction analysis of the resulting $\mathrm{Cr}_{3} \mathrm{C}_{2}-$ Cu60Ni20Mn20 composite are shown in Fig. 4.3, from which it is evident that all the lines of theoretically calculated diffractogram correspond to the lines on the experimental diffractogram, and there are no unidentified lines, that is, the phase composition is established unambiguously. It was found that there are three phases in the material, namely a $\mathrm{Cu}$-based solid solution with a lattice parameter of $3.64 \AA$ (space group Fm-3m, cubic crystal system), $\mathrm{Cr}_{3} \mathrm{C}_{2}$ with lattice parameters $\mathrm{a}=5.53 \AA, \mathrm{b}=2.82 \AA$ and $\mathrm{c}=11.48$ $\AA$ (spatial group Pnma, rhomboid crystal system) and complex carbide of chromium manganese $(\mathrm{Cr}, \mathrm{Mn})_{7} \mathrm{C}_{3}$ with lattice parameters: $\mathrm{a}=7.05 \AA$, $\mathrm{b}=12.10 \AA, \mathrm{c}=4,53 \AA$ (space group Pmcn, rhombic crystal system). The number of phases according to the results of the $\mathrm{X}$-ray diffraction analysis is in mass. \%: solid solution based on $\mathrm{Cu}-35 \%, \mathrm{Cr}_{3} \mathrm{C}_{2}-54 \%$, complex carbide $(\mathrm{Cr}, \mathrm{Mn})_{7} \mathrm{C}_{3}-11 \%$. 


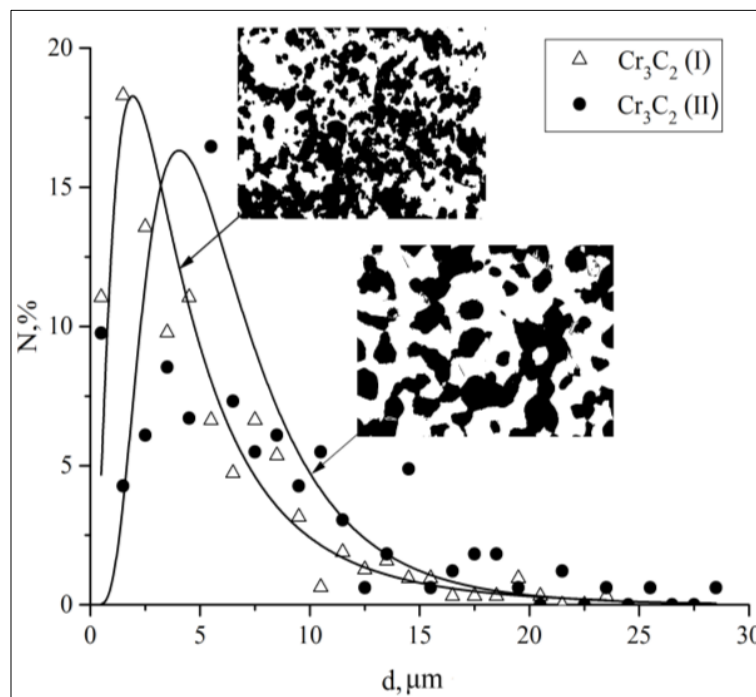

$\mathbf{a}$

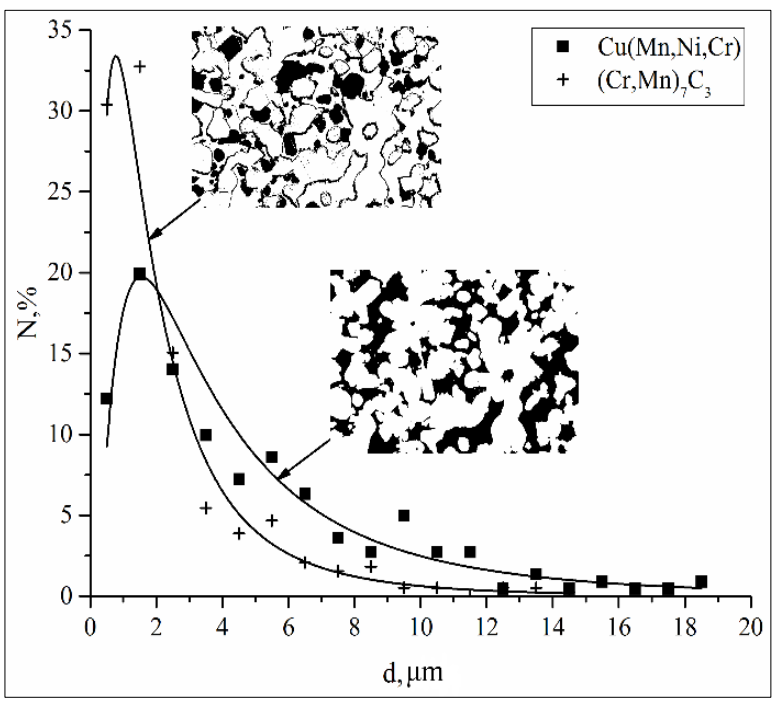

b

Fig. 4.2. Comparative analysis of the phase distribution by size is approximated by the lognormal distribution law:

$a-\mathrm{Cr}_{3} \mathrm{C}_{2}$ in the initial and infiltrated states; $b$-carbide phase formed in the process of infiltration and binder alloy

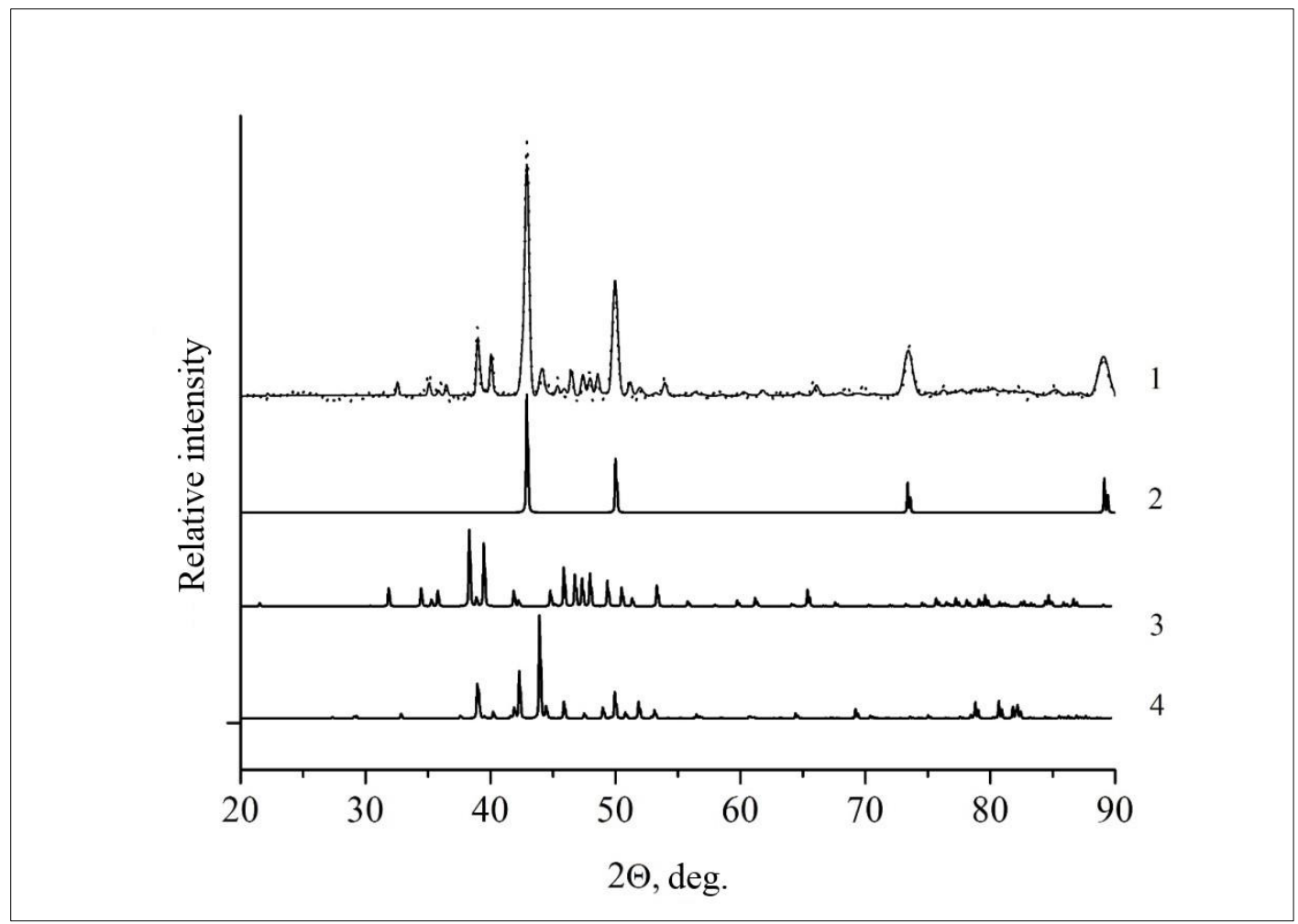

Fig. 4.3. Results of $X$-ray analysis of cermet $\mathrm{Cr}_{3} \mathrm{C}_{2}$-Cu60Ni20Mn20:

1 - experimental diffractogram (dotted line) and theoretical calculated diffractogram (solid line), 2, 3, 4-theoretically calculated diffractograms for solutions based on $\mathrm{Cu}, \mathrm{Cr}_{3} \mathrm{C}_{2}$ and $(\mathrm{Cr}, \mathrm{Mn})_{7} \mathrm{C}_{3}$ 
An analysis of the character of the distribution of elements along a line (L) passing through the interphase boundaries (Fig. 4.4) shows that bonding between the carbide phase and the binder occurs mainly due to Mn which diffuses from the binder to the carbide phase, contributes to the formation phase interconnection due to the allocation of a new structural component, namely, a solid solution based on the lower chromium carbide $(\mathrm{Cr}, \mathrm{Mn})_{7} \mathrm{C}_{3}$, which is allocated predominantly along the boundaries of the grains of the $\mathrm{Cr}_{3} \mathrm{C}_{2}$. Along with this, on the boundary of $\mathrm{Cr}_{3} \mathrm{C}_{2}-$ binder at the expense of the redistribution of $\mathrm{Cr}, \mathrm{Ni}$ and $\mathrm{Mn}$, a diffusion zone with a width of about $5 \mu \mathrm{m}$ is formed. This indicates a strong connection between the carbide grains and the matrix phase.
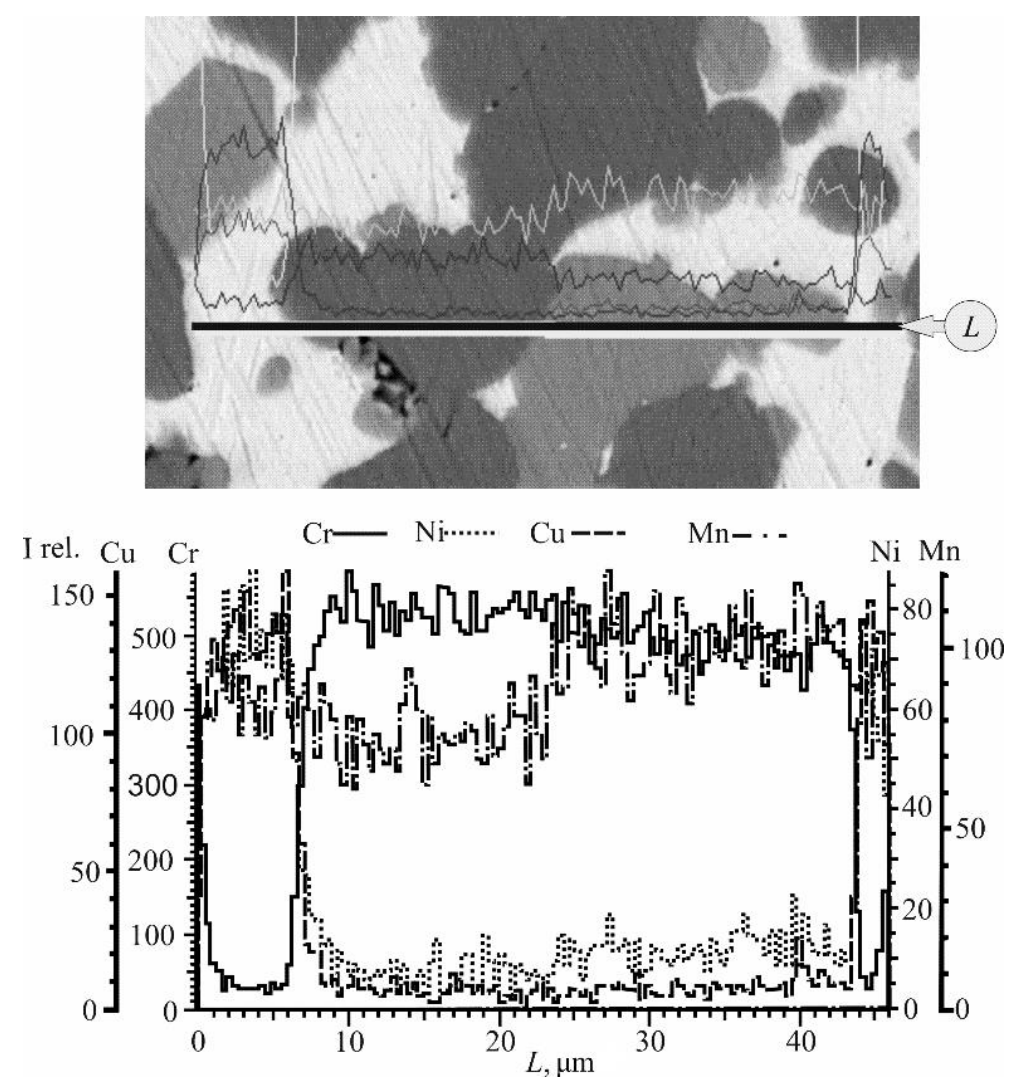

Fig. 4.4. Distribution of chemical elements on the interphase boundaries in cermet $\mathrm{Cr}_{3} \mathrm{C}_{2}-\mathrm{Cu} 60 \mathrm{Ni20Mn20}{ }^{99}$

Thus, according to the results of microscopic studies, it can be seen that the material obtained can be simulated by a matrix-reinforced structure.

99 Присяжнюк П.М. Шіхаб Т., Панчук В.Г Формування структури керметів Сr3С2-МНМц 60-20-20. Фізико-хімічна механіка матеріалів. Львів, 2016. № 52(2). C. 43-47. 


\subsection{Determination of thermophysical properties of $\mathrm{Cr}_{3} \mathrm{C}_{2}$ -}

\section{Cu60Ni20Mn20 composites on the basis of modeling their structure}

To determine the characteristics of the shape on a binary image of the microstructure (Fig. 4.5, a), using the ImageJ program, the grain of the ceramic phase was randomly selected (Fig. 4.5, b). For each of them, the Freeman code and the coefficients of the parametric equations $\left(\mathrm{a}_{\mathrm{ni}}, \mathrm{b}_{\mathrm{ni}}, \mathrm{c}_{\mathrm{ni}}\right.$, $\mathrm{d}_{\mathrm{ni}}$ ) were determined. Then the average arithmetic values of the coefficients for each $n$-th harmonic were determined by the formulas:

$$
a_{n m}=\sum_{i=1}^{N} \frac{a_{n i}}{N}, b_{n m}=\sum_{i=1}^{N} \frac{b_{n i}}{N}, c_{n m}=\sum_{i=1}^{N} \frac{c_{n i}}{N}, d_{n m}=\sum_{i=1}^{N} \frac{d_{n i}}{N},
$$

where $\mathrm{N}$ is the number of grains $(\mathrm{N}=21)$

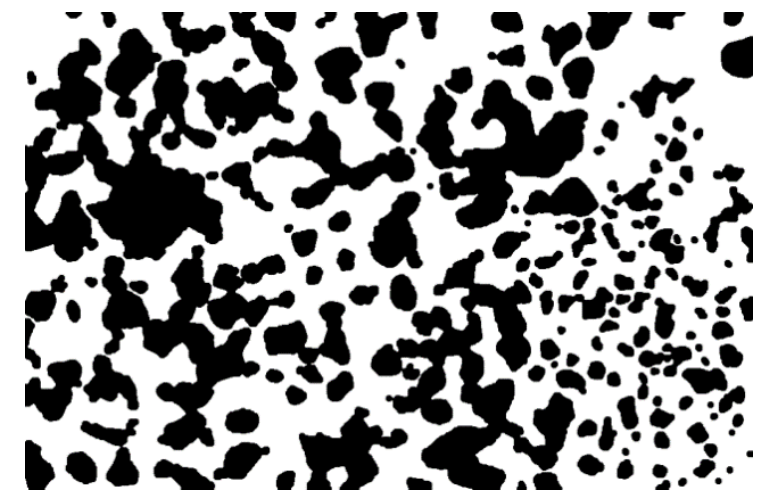

a

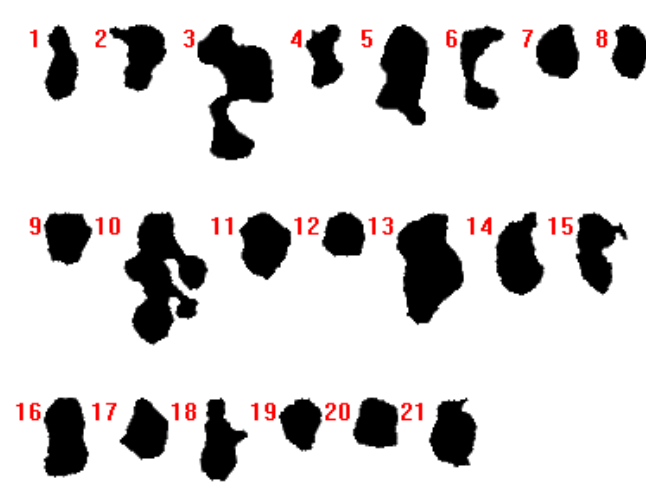

b

Fig. 4.5. Binary image of structure $\times 100$ (a), grains selected to determine the averaged form (b)

After substituting the values of the calculated coefficients into the parametric equation (2.12) and the transition to the polar coordinates, the main contour of the grains of the carbide phase was obtained (Fig. 4.6, a). Considering that the average contour has a rounded elongated shape of the image of a carbide particle of medium form in a three-dimensional form was obtained by rotating the contour around the axis on which the largest radius measured from the center of mass was located (Fig. 4.6, b). 


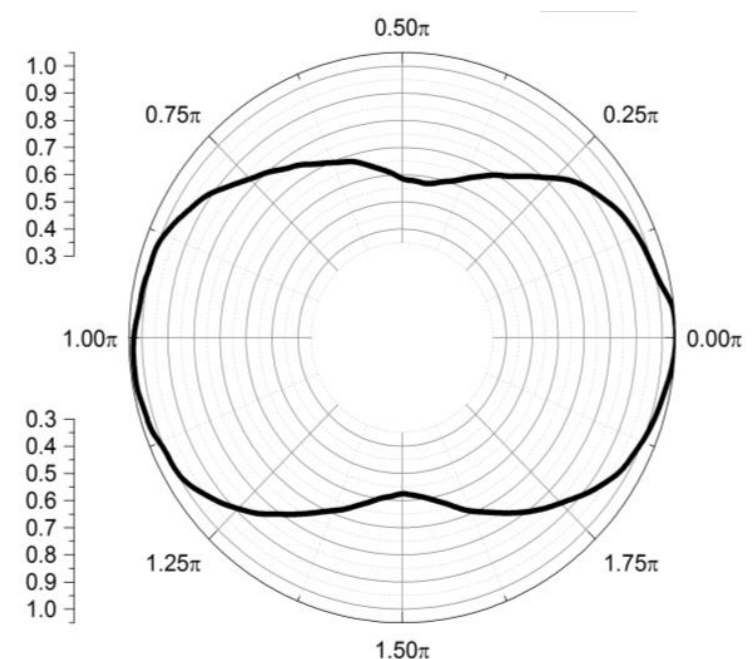

$\mathbf{a}$

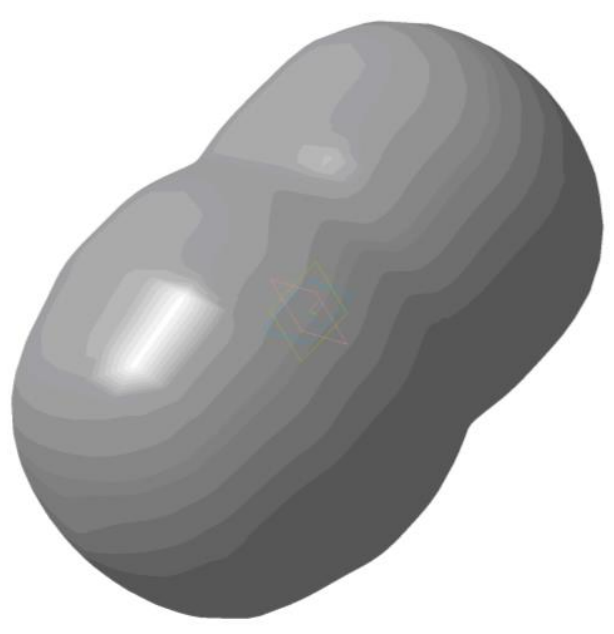

b

Fig. 4.6. The average contour (a), and the average grain form (b) of the carbide phase in the $\mathrm{Cr}_{3} \mathrm{C}_{2}$-Cu60Ni20Mn20 composite

The space matrix-reinforced structure (Fig. 4.7) was generated by translating the medium-sized carbide grain into a three-dimensional form using the Digimat 6.0.1 software. The homogenization of it, based on the Mori-Tanaka algorithm, considering the characteristics of the matrix and the carbide phase, allow to calculate integral thermophysical characteristics necessary for the determination of thermal calculations when working on rings of mechanical seals.

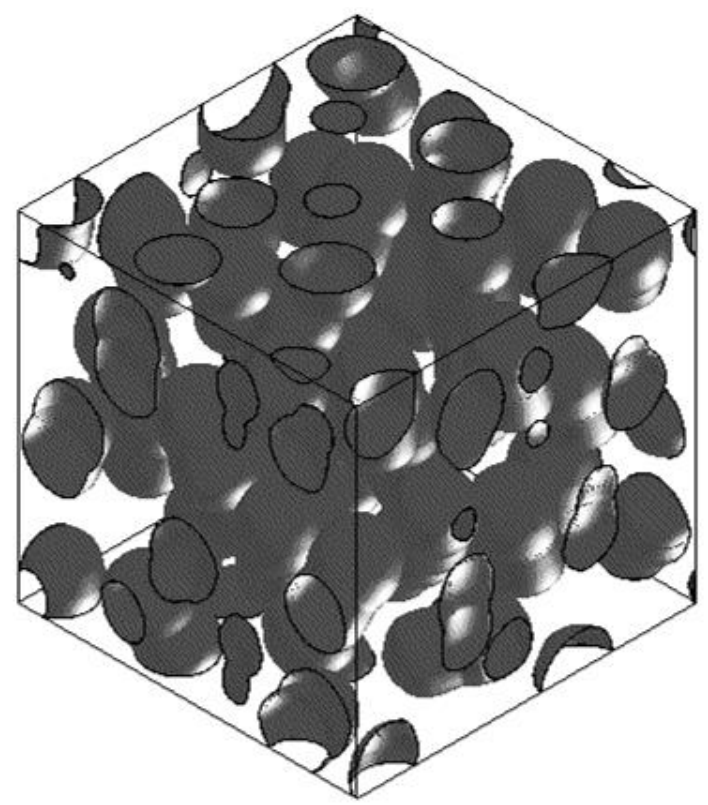

Fig. 4.7. Modified fragment of the structure of the $\mathrm{Cr}_{3} \mathrm{C}_{2}-\mathrm{Cu} 60-\mathrm{Ni20}-\mathrm{Mn} 20$ composite 


\subsection{Thermal calculation of mechanical seal rings in a pair of composite $\mathrm{Cr}_{3} \mathrm{C}_{2}$-Cu60-Ni20-Mn20 - self-bonded SiC}

With the vast majority of centrifugal pumps, the common occurrence is the failure of mechanical seals at startup and in the initial stages of operation. This is due to the absence or insufficient amount of the working environment on the contact surfaces of the rings, which leads to sharp temperature variations due to dry friction. Thermal cracking is the most dangerous for rings from ceramic materials with low thermal conductivity and crack resistance. Therefore, when selecting the materials of rings, their thermal calculation is a prerequisite for predicting the efficiency of the mechanical seal. According to Kingirie's work ${ }^{100}$. Factors affecting thermal stress resistance of ceramic materials. The maximum permissible temperature difference $\Delta \mathrm{T}$, which can withstand the material of the rings, is:

$$
\Delta T=\frac{\sigma(1-v)}{E \alpha},
$$

where $\sigma$ is the strength limit, MPa, $v$ is the Poisson coefficient, E is the elastic modulus, $\mathrm{MPa}$, and $\alpha$ is the coefficient of thermal expansion.

Applying the integral Laplace transform for equations (2.16) and (2.17) they will take the form:

$$
\begin{gathered}
\frac{d^{2} \overline{T_{1}}(x, s)}{d x^{2}}-\frac{\left(s+b_{1}\right)}{a_{1}} \bar{T}_{1}(x, s)=0 ; \quad(x<0) \\
\frac{d^{2} \overline{T_{2}}(x, s)}{d x^{2}}-\frac{\left(s+b_{2}\right)}{a_{2}} \overline{T_{2}}(x, s)=0 . \quad(x>0)
\end{gathered}
$$

Boundary conditions in the form of images will have the form:

$$
\begin{gathered}
\overline{T_{1}}(0, s)=\overline{T_{2}}(0, s) \\
\lambda_{1} \frac{\partial \bar{T}_{1}(0, s)}{\partial x}-\frac{\partial \overline{T_{2}}(0, s)}{\partial x}=\bar{q}(s) \\
\left|\bar{T}_{1}(x, s)\right|<+\infty, \quad x<0 \\
\left|\bar{T}_{2}(x, s)\right|<+\infty, \quad x>0
\end{gathered}
$$

The solution of ordinary differential equations (4.3) and (4.4) will have a look:

100 Kingery W.D. Factors affecting thermal stress resistance of ceramic materials. Journal of the American Ceramic Society. 1955. №38(1). C. 3-15. 


$$
\begin{aligned}
& \bar{T}_{1}(x, s)=A_{1} \exp \left(\sqrt{\frac{s+b_{1}}{a_{1}} x}\right)+B_{1} \exp \left(-\sqrt{\frac{s+b_{1}}{a_{1}} x}\right), x<0 \\
& \bar{T}_{2}(x, s)=A_{2} \exp \left(\sqrt{\frac{s+b_{2}}{a_{2}} x}\right)+B_{2} \exp \left(-\sqrt{\frac{s+b_{2}}{a_{2}} x}\right), x>0
\end{aligned}
$$

Considering the boundary conditions (4.5-4.8) and taking $\mathrm{B} 1=0$ and $\mathrm{A}_{2}=0$

$$
\begin{aligned}
& \bar{T}_{1}(x, s)=A_{1} \exp \left(\sqrt{\frac{s+b_{1}}{a_{1}} x}\right) \\
& \bar{T}_{2}(x, s)=B_{2} \exp \left(-\sqrt{\frac{s+b_{2}}{a_{2}} x}\right) .
\end{aligned}
$$

Taking into account that

$$
\begin{gathered}
\frac{\partial \bar{T}_{1}(x, s)}{\partial x}=A_{1} \sqrt{\frac{s+b_{1}}{a_{1}}} \exp \left(\sqrt{\frac{s+b_{1}}{a_{1}} x}\right) ; \\
\frac{\partial \overline{T_{2}}(x, s)}{\partial x}=-B_{2} \sqrt{\frac{s+b_{2}}{a_{2}}} \exp \left(-\sqrt{\frac{s+b_{2}}{a_{2}} x}\right) . \\
\frac{\partial \bar{T}_{1}(0, s)}{\partial x}=A_{1} \sqrt{\frac{s+b_{1}}{a_{1}}} \text { та } \frac{\partial \overline{T_{2}}(0, s)}{\partial x}=-B_{2} \sqrt{\frac{s+b_{2}}{a_{2}}} .
\end{gathered}
$$

Taking into account the boundary conditions (4.5) and (4.6)

$$
\begin{gathered}
A_{1}=B_{2} \\
A_{1} \lambda_{1} \sqrt{\frac{s+b_{1}}{a_{1}}}+B_{2} \lambda_{2} \sqrt{\frac{s+b_{2}}{a_{2}}}=\bar{q}(s),
\end{gathered}
$$

in accordance

$$
A_{1}=\frac{\bar{q}(s)}{\frac{\lambda_{1}}{\sqrt{a_{1}} \sqrt{s+b_{1}}}+\frac{\lambda_{2}}{\sqrt{a_{2}}} \sqrt{s+b_{2}}},
$$

after entering the notation

$$
K_{\lambda a}=\frac{\lambda_{1} \sqrt{a_{2}}}{\lambda_{2} \sqrt{a_{1}}},
$$

then 


$$
\begin{gathered}
A_{1}=\frac{\bar{q}(s) K_{\lambda a} \sqrt{a_{1}}}{\lambda_{1}\left(K_{\lambda a} \sqrt{s+b_{1}}+\sqrt{s+b_{2}}\right)} ; \\
B_{2}=\frac{\bar{q}(s) \sqrt{a_{2}}}{\lambda_{2}\left(K_{\lambda a} \sqrt{s+b_{1}}+\sqrt{s+b_{2}}\right)} .
\end{gathered}
$$

By the substitution of the coefficients $A_{1}$ and $B_{2}$ in the equations (4.11) and (4.12), the solution to the problem in images will be:

$$
\begin{aligned}
& \bar{T}_{1}(x, s)=\frac{\bar{q}(s) K_{\lambda a} \sqrt{a_{1}}}{\lambda_{1}\left(K_{\lambda a} \sqrt{s+b_{1}}+\sqrt{s+b_{2}}\right)} \exp \left(\sqrt{\frac{s+b_{1}}{a_{1}} x}\right), x<0 \\
& \bar{T}_{2}(x, s)=\frac{\bar{q}(s) \sqrt{a_{2}}}{\lambda_{2}\left(K_{\lambda a} \sqrt{s+b_{1}}+\sqrt{s+b_{2}}\right)} \exp \left(-\sqrt{\frac{s+b_{2}}{a_{2}} x}\right) . x>0
\end{aligned}
$$

For conditions that correspond to the heat dissipation of the mechanical seal rings from heterogeneous materials on the contact surface, the force constant force will act as follows:

$$
\bar{q}(s)=\frac{q_{0}}{s} .
$$

Having multiplied numerators and denominators of equations (4.22) and (4.23) into a multiplier

$$
\left(K_{\lambda a} \sqrt{s+b_{1}}+\sqrt{s+b_{2}}\right),
$$

as well as having replaced the variable and entering the notation

$$
m=\frac{K_{\lambda a}^{2} b_{1}-b_{2}}{K_{\lambda a}^{2}-1}
$$

For ring 1 there is

$$
\bar{T}_{1}(x, s)=\frac{\bar{q}_{0} K_{\lambda a} \sqrt{a_{1}}\left(K_{\lambda a} \sqrt{s+b_{1}}-\sqrt{s+b_{2}}\right)}{\lambda_{1} s\left(K_{\lambda a}^{2}-1\right)(s+m)} \exp \left(-\sqrt{\frac{s+b_{1}}{a_{1}} z}\right), z>0,
$$

and for ring 2

$$
\bar{T}_{2}(x, s)=\frac{\bar{q}_{0} K_{\lambda a} \sqrt{a_{2}}\left(K_{\lambda a} \sqrt{s+b_{1}}-\sqrt{s+b_{2}}\right)}{\lambda_{2} s\left(K_{\lambda a}^{2}-1\right)(s+m)} \exp \left(-\sqrt{\frac{s+b_{2}}{a_{2}} x}\right), x>0,
$$


For ease of use, the table images depicted in ${ }^{101}$ equations (4.25) and (4.26) were rewritten in the form

$$
\begin{gathered}
\bar{T}_{1}(-z, s)=\frac{\bar{q}_{0} K_{\lambda a} \sqrt{a_{1}}}{\lambda_{1}\left(K_{\lambda a}^{2}-1\right)} \times \\
\times\left[K_{\lambda a} \frac{1}{s} \frac{\sqrt{s+b_{1}}}{(s+m)} \exp \left(-\sqrt{\frac{s+b_{1}}{a_{1}} z}\right)-\frac{1}{s} \frac{\sqrt{s+b_{2}}}{(s+m)} \exp \left(-\sqrt{\frac{s+b_{1}}{a_{1}} z}\right)\right], z>0, \\
\bar{T}_{2}(x, s)=\frac{\bar{q}_{0} K_{\lambda a} \sqrt{a_{2}}}{\lambda_{2}\left(K_{\lambda a}^{2}-1\right)} \times \\
\times\left[K_{\lambda a} \frac{1}{S} \frac{\sqrt{s+b_{1}}}{(s+m)} \exp \left(-\sqrt{\frac{s+b_{2}}{a_{2}} x}\right)-\frac{1}{s} \frac{\sqrt{s+b_{2}}}{(s+m)} \exp \left(-\sqrt{\frac{s+b_{2}}{a_{2}} x}\right)\right], x>0,
\end{gathered}
$$

Using standard trasformations

$$
\begin{gathered}
L^{-1}\left[\frac{\sqrt{s+\beta}}{s+a}\right] \exp (-\sqrt{\alpha(s+\beta)})=\frac{\sqrt{\beta-a} \exp (-a t)}{2} \times \\
\times\left\{\begin{array}{c}
\exp (-\sqrt{\alpha(s+\beta)}) \operatorname{erfc}\left(\frac{1}{2} \sqrt{\frac{\alpha}{t}}-\sqrt{(\beta-a) t}\right)- \\
-\exp (\sqrt{\alpha(s-\beta)}) \operatorname{erfc}\left(\frac{1}{2} \sqrt{\frac{\alpha}{t}}+\sqrt{(\beta-a) t}\right)
\end{array}\right\} \\
+\frac{1}{\sqrt{\pi t}} \exp \left(-\beta t-\frac{\alpha}{4 t}\right) ; \\
L^{-1}\left[\frac{\sqrt{s+a}}{s+b}\right]=\frac{\exp (-a t)}{\sqrt{\pi t}}+\sqrt{a-b} \exp (-b t) \operatorname{erfc}(\sqrt{(a-b) t}) ; \\
L^{-1}\left[\frac{\exp (-\sqrt{\alpha(s-\beta)})}{s}\right]=\frac{1}{2}\left[\begin{array}{l}
\left.\exp (-\sqrt{\alpha \beta}) \operatorname{erfc}\left(\frac{1}{2} \sqrt{\frac{\alpha}{t}}+\sqrt{\beta t}\right)+\right] \\
\left.+\exp (-\sqrt{\alpha \beta}) \operatorname{erfc}\left(\frac{1}{2} \sqrt{\frac{\alpha}{t}}-\sqrt{\beta t}\right)\right]
\end{array}\right.
\end{gathered}
$$

101 Диткин В.А., Прудников А.П. Справочник по операционному исчислению. Москва : Высшая школа, 1965. 466 с. 
Given the property of the Laplace transform:

$$
L[f(t)]=F(s) ; L^{-1}\left[\frac{1}{s} F(s)\right]=\int_{0}^{t} f(\theta) d \theta,
$$

as well as the multiplication theorems, according to which for

$$
\begin{gathered}
F_{1}(s)=L\left[f_{1}(t)\right] \text { i } F_{2}(s)=L\left[f_{2}(t)\right] \\
L^{-1}\left[F_{1}(s) \times F_{2}(s)\right]=\int_{0}^{t} f_{1}(\theta) f_{2}(t-\theta) d \theta=\int_{0}^{t} f_{1}(t-\theta) f_{2}(\theta) d \theta .
\end{gathered}
$$

The equations 4.27 and 4.28 will change their appearance to the original

$$
T_{1}(-z, t)=\frac{q_{0} K_{\lambda a} \sqrt{a_{1}}}{\lambda_{1}\left(K_{\lambda a}^{2}-1\right)} \times\left[K_{\lambda a} J_{1}-J_{2}\right]
$$

where

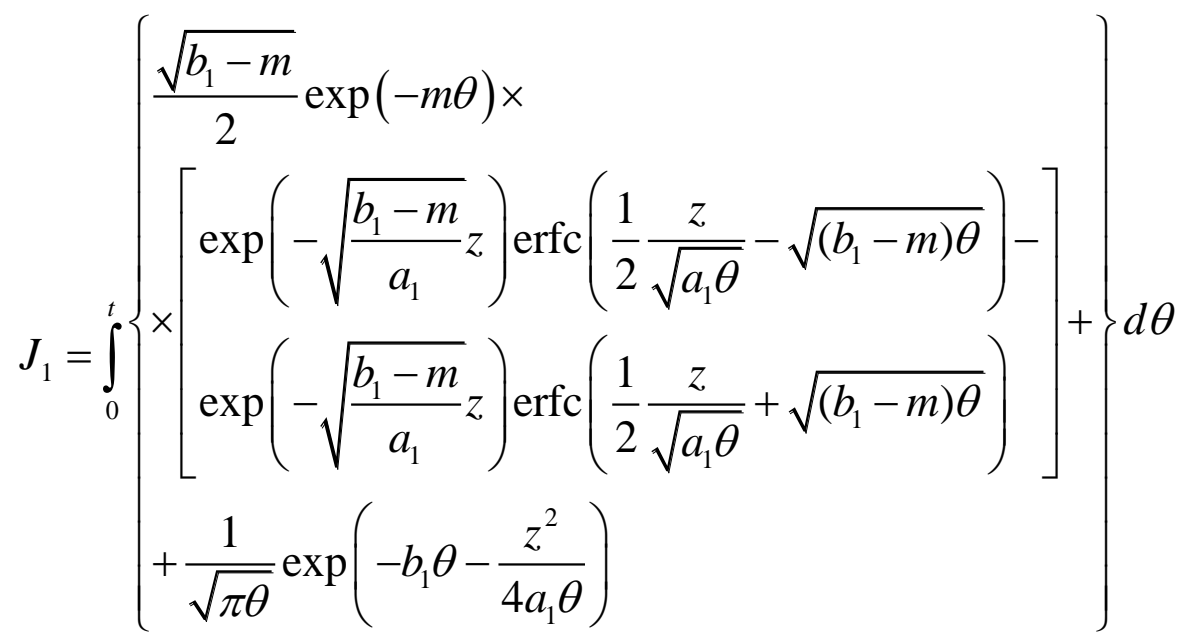

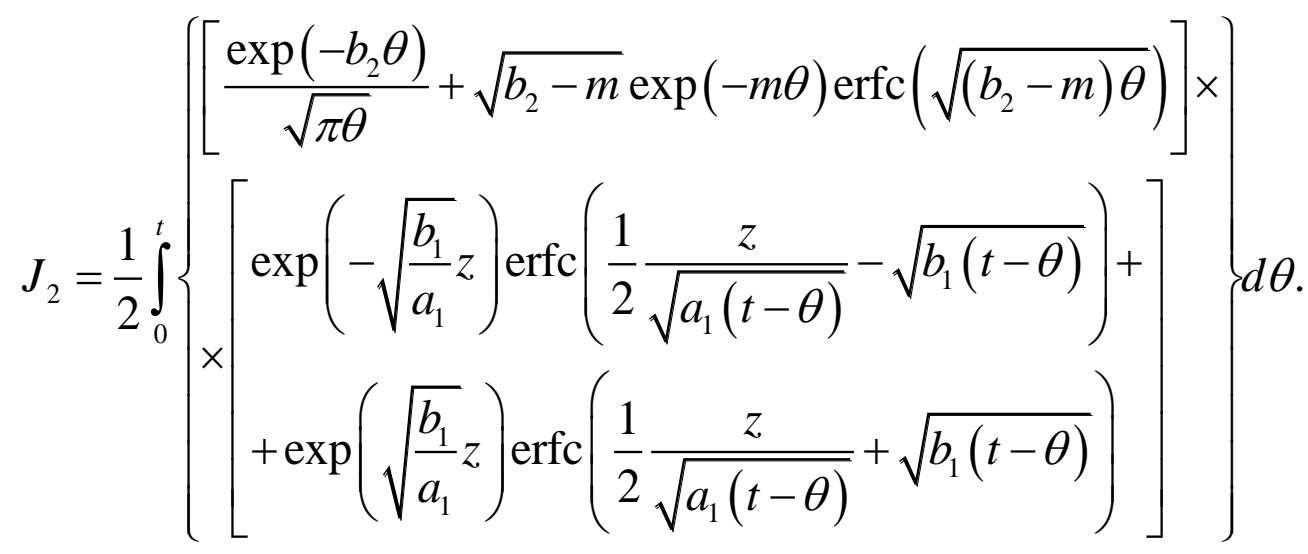




$$
T_{2}(x, s)=\frac{q_{0} K_{\lambda a} \sqrt{a_{2}}}{\lambda_{2}\left(K_{\lambda a}^{2}-1\right)} \times\left[K_{\lambda a} J_{3}-J_{4}\right] .
$$

Where

$$
\begin{aligned}
& \int\left[\frac{\exp \left(-b_{1} \theta\right)}{\sqrt{\pi \theta}}+\sqrt{b_{1}-m} \exp (-m \theta) \operatorname{erfc}\left(\sqrt{\left(b_{1}-m\right) \theta}\right)\right] \times
\end{aligned}
$$

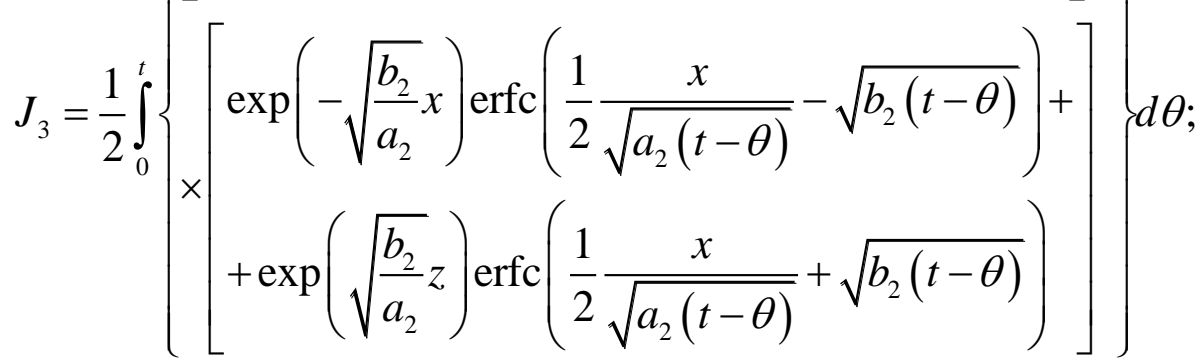

$$
\begin{aligned}
& J_{4}=\int_{0}^{t}\left\{\begin{array}{l}
\frac{\sqrt{b_{2}-m}}{2} \exp (-m \theta) \times \\
{\left[\exp \left(-\sqrt{\frac{b_{2}-m}{a_{2}}} x\right) \operatorname{erfc}\left(\frac{1}{2} \frac{x}{\sqrt{a_{2} \theta}}-\sqrt{\left(b_{2}-m\right) \theta}\right)-\right]} \\
-\exp \left(\sqrt{\left.\frac{b_{2}-m}{a_{2}} x\right) \operatorname{erfc}\left(\frac{1}{2} \frac{x}{\sqrt{a_{2} \theta}}+\sqrt{\left(b_{2}-m\right) \theta}\right)}\right] \\
+\frac{1}{\sqrt{\pi \theta}} \exp \left(-b_{2} \theta-\frac{x^{2}}{4 a_{2} \theta}\right)
\end{array}\right\} d \theta .
\end{aligned}
$$

If take $b_{1}=b_{2}=b$, the solution of the problem in the originals will look like:

$$
\begin{aligned}
& T_{1}(-z, t)=\frac{q_{0} K_{\varepsilon}}{2 \lambda_{1}\left(K_{\varepsilon}+1\right)} \sqrt{\frac{a_{1}}{b}} \times \\
& \times\left[\exp \left(-\sqrt{\frac{b}{a_{1}}} z\right) \operatorname{erfc}\left(\frac{z}{2 \sqrt{a_{1} t}}-\sqrt{b t}\right)-\exp \left(-\sqrt{\frac{b}{a_{1}}} z\right) \operatorname{erfc}\left(\frac{z}{2 \sqrt{a_{1} t}}+\sqrt{b t}\right)\right], \\
& T_{2}(x, t)=\frac{q_{0} \sqrt{a_{2}}}{2 \lambda_{2}\left(K_{\varepsilon}+1\right)} \sqrt{\frac{a_{2}}{b}} \times \\
& \times\left[\exp \left(-\sqrt{\frac{b}{a_{2}}} x\right) \operatorname{erfc}\left(\frac{x}{2 \sqrt{a_{2} t}}-\sqrt{b t}\right)-\exp \left(-\sqrt{\frac{b}{a_{2}}} x\right) \operatorname{erfc}\left(\frac{x}{2 \sqrt{a_{1} t}}+\sqrt{b t}\right)\right] .
\end{aligned}
$$


In the case of friction of the mechanical seal rings $\mathrm{q}_{0}=\mathrm{Q} / \mathrm{F}$. Here $\mathrm{Q}(\mathrm{J} / \mathrm{s})$ is the heat generated during friction ${ }^{5}$ :

$$
Q=p \mu v_{m} F,
$$

where $v_{m}=\frac{\pi d_{m} n}{6000}-$ average speed, $\mathrm{d}_{\mathrm{m}}$ - average diameter, $\mu-$ coefficient of friction, $\mathrm{n}$ - speed, $\mathrm{F}$ - contact area, $\mathrm{p}-$ contact pressure. For mechanical seal of the ONC type : $p=35 \mathrm{~kg} / \mathrm{cm}^{2}, \mathrm{~d}_{\mathrm{m}}=8.7 \mathrm{~cm}$, $\mathrm{n}=3600 \mathrm{rpm}, \mu$ for dry friction ( $\mathrm{SiC}$ by $\mathrm{SiC}-0.32$, SiC by $\mathrm{Cr} 3 \mathrm{C} 2-\mathrm{Cu} 60$ Ni20-Mn20 - 0.12), $\mathrm{F}=2185 \mathrm{~mm}^{2}$. After substituting data into equation (4.33) we obtain:

$$
\begin{aligned}
& q_{0}=\frac{Q}{F}=35 \times 0,32 \times \frac{3,14 \times 8,7 \times 3600}{6000}=182.4 \text { for a SiC-SiC pair } \\
& q_{0}=\frac{Q}{F}=35 \times 0,12 \times \frac{3,14 \times 8,7 \times 3600}{6000}=68,4 \text {. for a pair of } \mathrm{SiC}-
\end{aligned}
$$

$\mathrm{Cr}_{3} \mathrm{C}_{2}$-Cu60-Ni20-Mn20

After substituting the values of the thermophysical characteristics of the rings and the measured values of the sliding friction coefficients, the dependences of the temperature distribution on the section of the rings depending on the distance to the contact area for the given time point were obtained in equations (4.31) and (4.32) (Fig. 4.8). As can be seen from the graphic dependencies, temperature stabilization in both friction pairs begins after $400 \mathrm{~s}$ of work. At the same time, for the SiC-SiC pair, the maximum temperature in the contact zone is $\sim 330{ }^{\circ} \mathrm{C}$, which is almost 3 times the temperature in the $\mathrm{SiC}-\mathrm{Cr}_{3} \mathrm{C}_{2}-\mathrm{Cu} 60 \mathrm{Ni} 20 \mathrm{Mn} 20$ contact zone. This is because of decrease in the coefficient of friction caused by the presence in the contact zone of the plastic phase (manganese metallurgy), which acts as solid lubricant due to the formation on the contact surfaces of a protective film containing the oxide phases of $\mathrm{Mn}, \mathrm{Cu}$ and $\mathrm{Ni}$ and is characterized by a high level of antifriction properties.

An analysis of the calculation of the kinetics of the temperature increase in the contact area and at the depth corresponding to the height of the working surfaces of the rings $(5 \mathrm{~mm})$ (Fig. 4.9, a, b). Shows that the use of the developed $\mathrm{Cr}_{3} \mathrm{C}_{2}-\mathrm{Cu} 60-\mathrm{Ni20}-\mathrm{Mn} 20$ composite in a pair with $\mathrm{SiC}$ provides a significant a lower level of temperature variation and, accordingly, allows for a high level of reliability. 


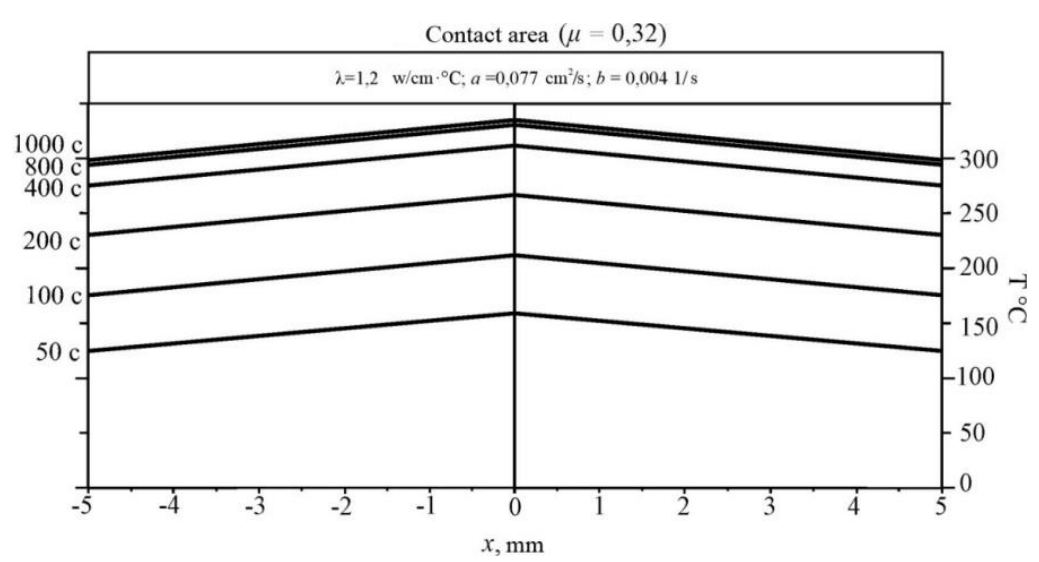

a)

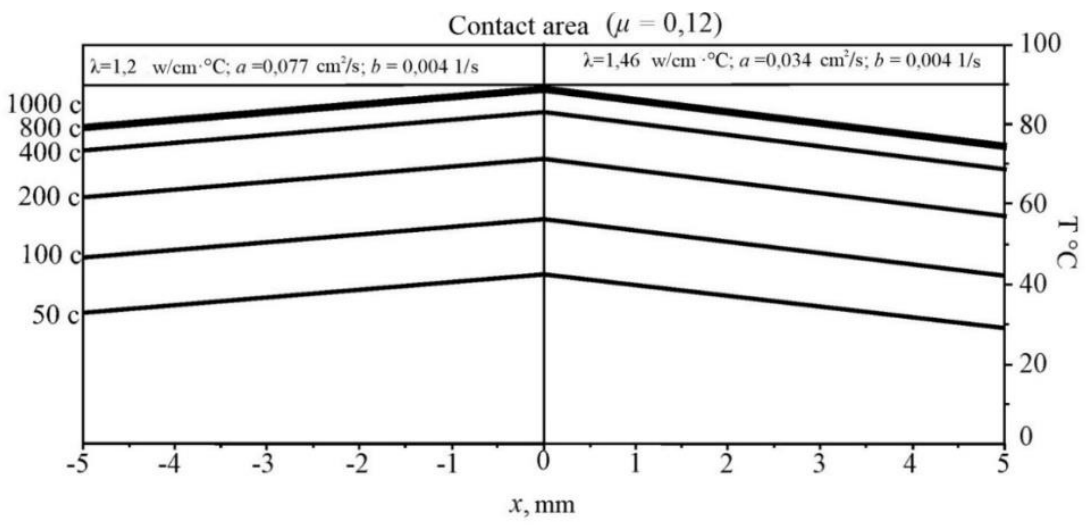

b)

Fig. 4.8. Results of calculation of temperature distribution in pairs of rings at friction, depending on the moment of time: a) is a SiC on SiC pair; b) is a SiC pair over $\mathrm{Cr}_{3} \mathrm{C}_{2}$-Cu60-Ni2O-Mn2O

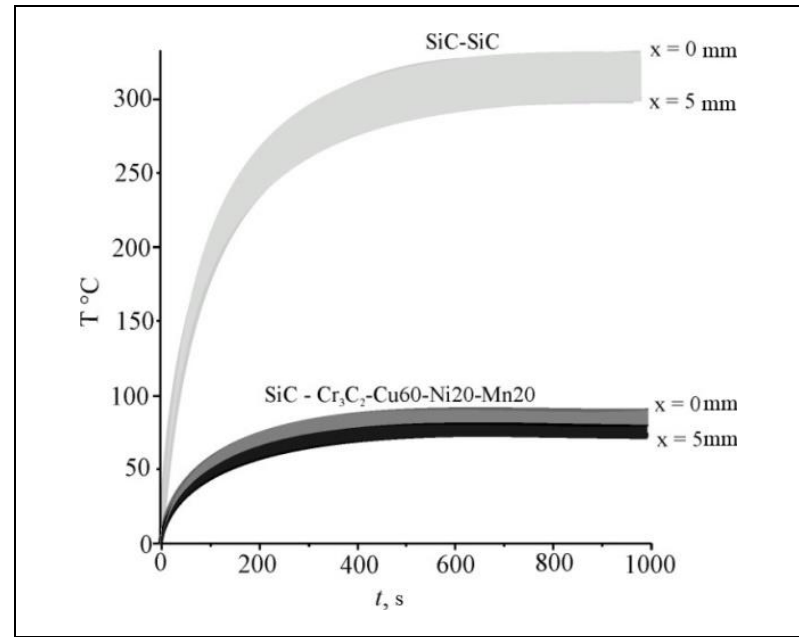

a)

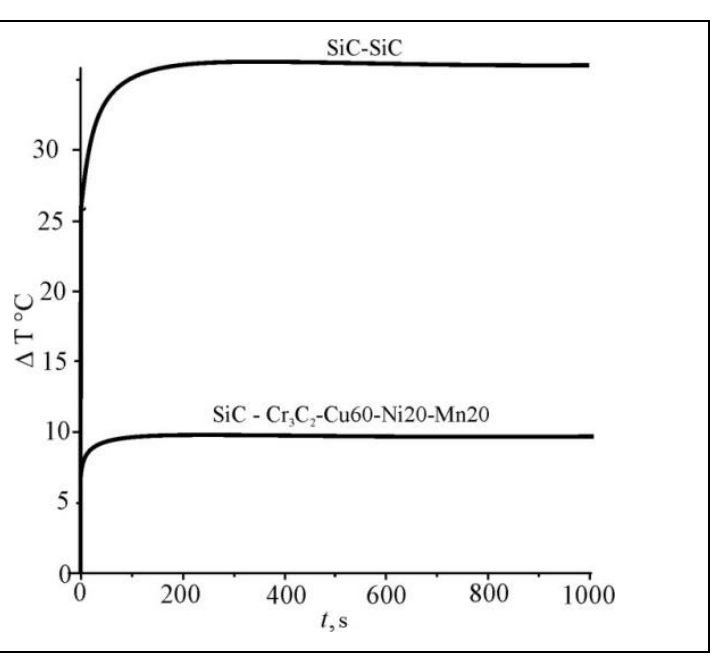

b)

Fig. 4.9. Results of calculation of temperature rise during friction (a) and corresponding temperature difference (b) and rub, depending on the time point:

a) is a SiC on SiC pair; b) is a SiC pair over $\mathrm{Cr}_{3} \mathrm{C}_{2}-\mathrm{Cu} 60-\mathrm{Ni2O}-\mathrm{Mn} 2 \mathrm{O}$ 
Comparison of the results of calculations based on the developed mathematical model and the data obtained on the basis of experimental studies (Fig. 4.10) shows that the developed mathematical model with sufficient (for engineering calculations) accurately describes the process of heat distribution in the conditions of dry friction of the working turns of the mechanical seals.

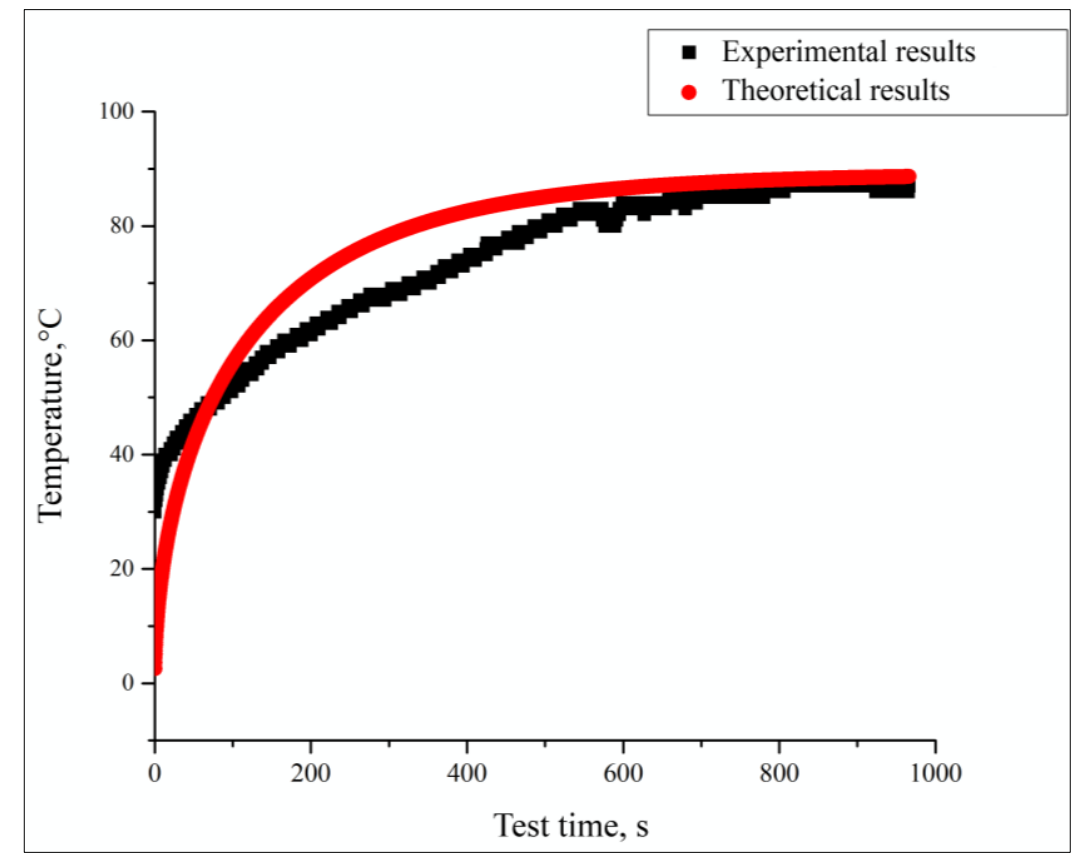

Fig. 4.10. Results of the calculation of temperature rise for estimated and experimental data $^{102}$

\section{Physical-mechanical and operational characteristics of the material of the rings of the mechanical seals on the basis of the system $\mathrm{Cr}_{3} \mathrm{C}_{2}-\mathrm{Cu} 60 \mathrm{Ni20Mn20}$}

\subsection{Frictional thermal resistance of rings of mechanical seal made from materials of the system $\mathrm{Cr}_{3} \mathrm{C}_{2}-\mathrm{Cu} 60 \mathrm{Ni20Mn} 20$}

In order to choose the optimal ratio of materials and their predictive behavior in different working conditions, a comprehensive study is required to study the phenomena that arise in the process of friction and wear. One of the most important factors is the temperature in the contact

102 Шлапак Л.С., Шіхаб Т.А., Присяжнюк П.М. та ін. Моделювання поширення тепла у кільцях торцевих ущільнень нафтогазопромислових насосів, виготовлених із композиту на основі карбіду хрому, за умов сухого тертя. Проблеми трибологіï. Хмельницький. 2018. № 3. С. 53-60. 
zone, the effect of which is determined by tests on frictional heat resistance.

In the conditions of oil and gas processing enterprises, experience shows that one of the criteria that determines the durability of work is the stability of the surfaces, rubbing to the effect of temperature fluctuations. This is particularly pronounced during start-ups, stops and emergency modes of operation. In the study of spent pairs of friction of the mechanical seals of oil and gas pumps, a significant part of rings that were out of service due to brittle fracture were found (Fig. 5.1). At the same time, the presence of traces of oxidation is observed on the surfaces.

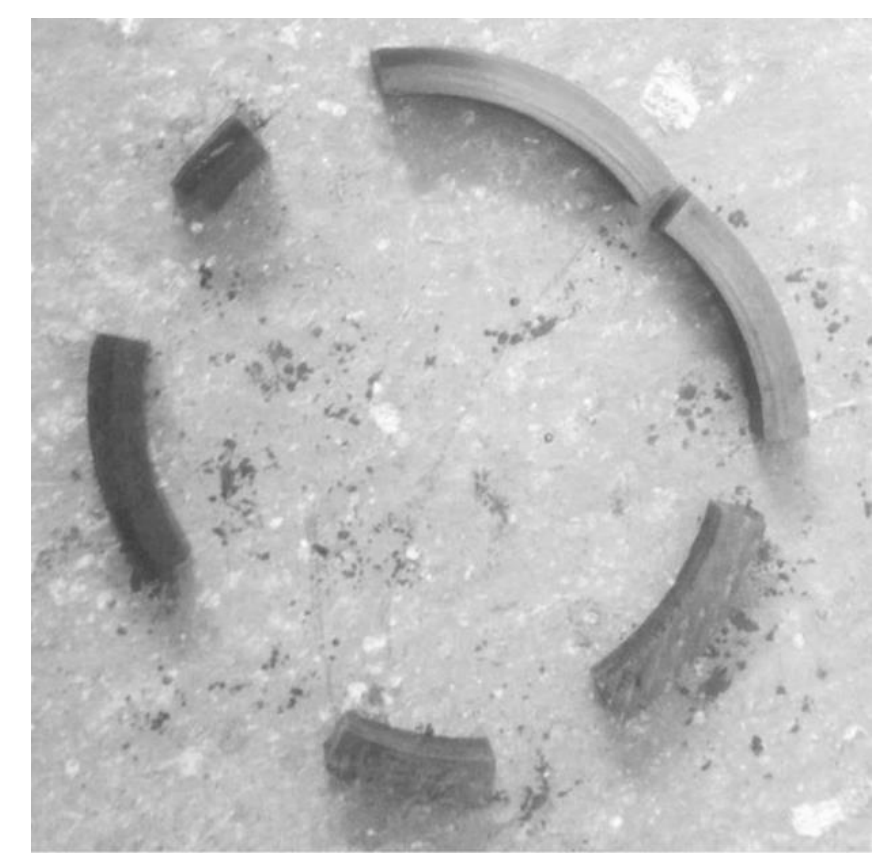

\section{Fig. 5.1. Ceramic ring of pump 4 NG5 $\times 2$, which has failed due to thermal cracking}

This type of destruction is due to the lack of anti-friction lubricant film on the sliding surfaces, which acts as a boundary layer, in the size of several molecular layers. In places where the destruction of the boundary layer is observed a sharp local increase of a temperature. In accordance with the foregoing, the most rational way to ensure the existence of the boundary layer is the rational selection of materials combination for friction pairs by conducting frictional heat resistance tests.

The tests were carried out by evaluating the coefficient of friction and the intensity of wear of the studied pairs at temperature - the main factor affecting the wear process as a result of changing the sliding speed and specific load according to the friction mode, which imitates the work of 
the real mechanical seal. SiC-SiC pairs were tested and $\mathrm{Cr}_{3} \mathrm{C}_{2}-$ Cu60Ni20Mn20 composites were SiC. The results of the tests are the dependence of the coefficient of friction and the intensity of wear on the speed of slip friction pairs. As can be seen from fig. 5.2. The friction coefficient in both pairs under investigation increases the slip speed initially and then decreases.

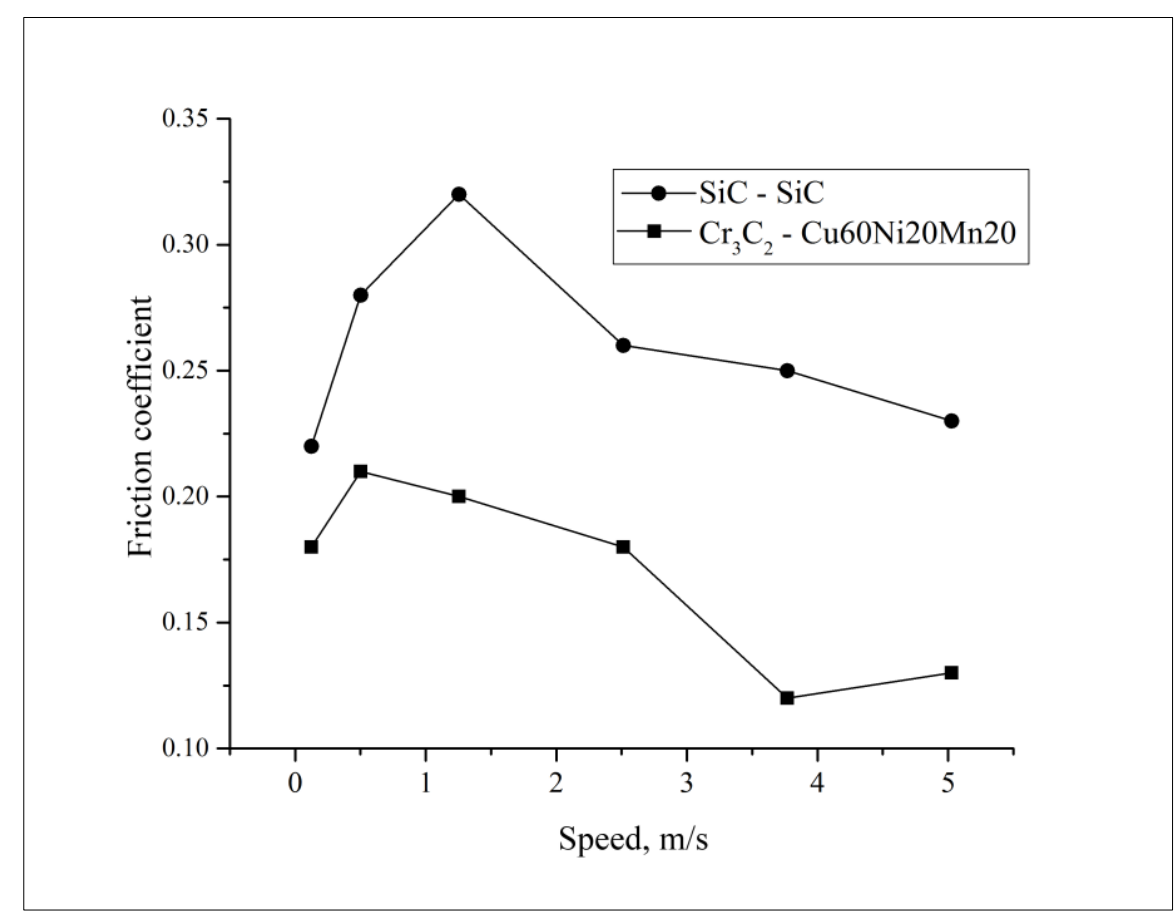

\section{Fig. 5.2. Dependence of the coefficient of friction on the sliding rate in the $\mathrm{SiC}$ pairs on $\mathrm{SiC}$ and $\mathrm{SiC}$ over the $\mathrm{Cr}_{3} \mathrm{C}_{2}-\mathrm{Cu} 60 \mathrm{Ni20Mn} 20$ composite}

Analyzing the obtained dependences it can be concluded that when the slip velocity is increased above $1 \mathrm{~m} / \mathrm{s}$, the coefficient of friction increases, and at its increase above $1 \mathrm{~m} / \mathrm{s}$ it is observed decrease and stabilization at the level of $\sim 0.25$ and 0.12 for $\mathrm{SiC}$ on $\mathrm{SiC}$ pairs, and $\mathrm{SiC}$ over $\mathrm{Cr}_{3} \mathrm{C}_{2}-$ Cu60Ni20Mn20 composite, respectively. For the studied pairs of maxima, the coefficient of friction fall on different sliding velocity rates. This is due to the different nature of the formation of the surface layer. In the friction pair $\mathrm{SiC}$ on $\mathrm{SiC}$ at high sliding rates, a surface layer formed of oxide phases of silicon, which causes a change in its color. Their presence due to formation in the zone of friction "third body" contributes to reducing the coefficient of friction. At the same time, in a pair of $\mathrm{SiC}$ over $\mathrm{Cr}_{3} \mathrm{C}_{2}-\mathrm{Cu} 60 \mathrm{Ni20Mn20}$ at high sliding velocities (above $2 \mathrm{~m} / \mathrm{s}$ ), the surface of the metal-ceramic ring retains a metallic luster. Such a change 
in the state of the surface layer can be explained by the processes of separation and plasticization of the metal bond, which is evenly distributed over the friction surfaces. Under these conditions, a superficial layer appears on the surface, which contributes to a reduction in the coefficient of friction.

The change in the coefficient of friction in the considered pairs is in close correlation with the values of the linear intensity of wear, which is also described by curves with the peaks at the peaks of the coefficients of friction (Fig. 5.3).

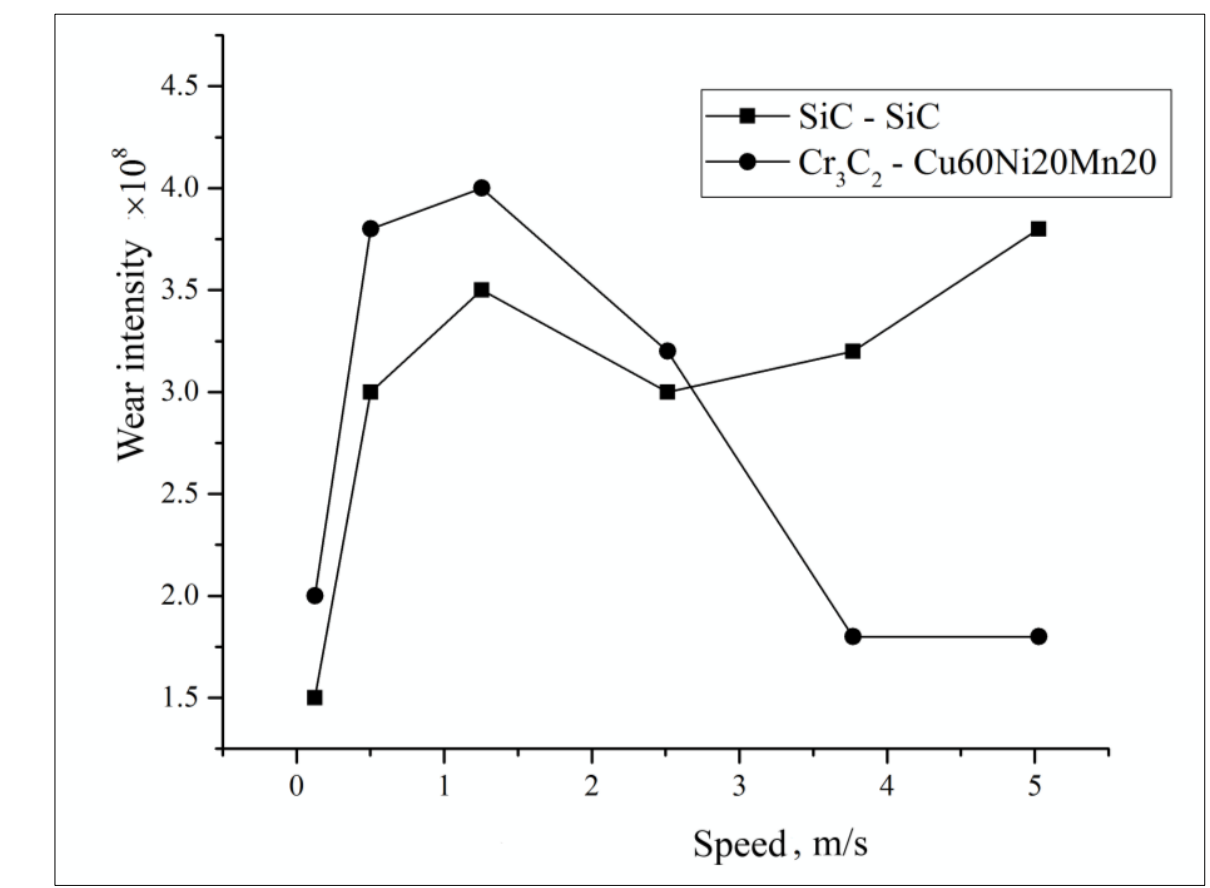

\section{Fig. 5.3. The dependence of the intensity of wear on the slip rate in the $\mathrm{SiC}$ on $\mathrm{SiC}$ pairs and $\mathrm{SiC}$ over $\mathrm{Cr}_{3} \mathrm{C}_{2}-\mathrm{Cu60Ni20Mn20}$ composite}

However, with an increase in the slip rate in $\mathrm{SiC}$ on $\mathrm{SiC}$ pairs, the intensity of wear shows a tendency to increase. This character of its change indicates the development of brittle fracturing of the surface due to the possible deflection of carbide grains and their penetration into the friction zone. This results in the surface of the sample and, as a result, the growth of the intensity of wear. At the same time, increasing the slip speed for $\mathrm{SiC}$ over $\mathrm{Cr}_{3} \mathrm{C}_{2}-\mathrm{Cu} 60 \mathrm{Ni} 20 \mathrm{Mn} 20$ over leads to the fact that in the initial stages the wear intensity increases in line with the increase of the coefficient of friction, and then mixes and stabilizes. This suggests that the manganese cupronickel binder holds carbide grains. Microscopic 
and chemical analysis of friction surfaces after tests (Fig. 5.4) shows that on the friction surfaces of a ceramic sample there is a thickening of the phase of rich copper. This indicates that the alloy-binder from the composite is transferred to the surface of the ceramic sample, forming an antifriction layer.

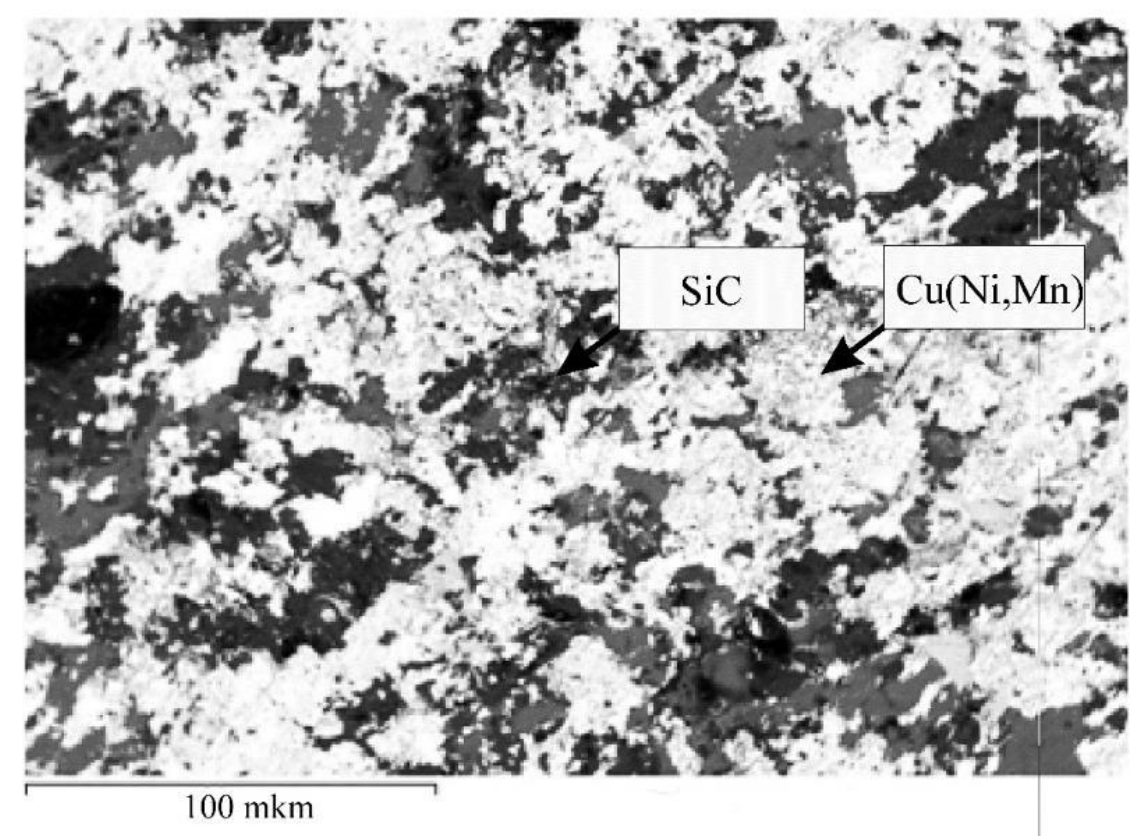

Fig. 5.4. Surface of friction $\mathrm{SiC}$ after tests on frictional heat resistance in pairs with composite $\mathrm{Cr}_{3} \mathrm{C}_{2}-\mathrm{Cu} 60 \mathrm{Ni20Mn20}$

\subsection{Mechanical properties of mechanical seal rings of $\mathrm{Cr}_{3} \mathrm{C}_{2}-\mathrm{Cu} 60 \mathrm{Ni20Mn20}$ system}

The level of mechanical properties of mechanical seal materials is provided by combining the dispersion (using chromium as a reinforcing phase) and dispersion strengthening, which is due to the separation of intermetallic compounds in the matrix of the developed composite. As shown in Table 5.1. The level of mechanical properties of the material developed essentially depends on the temperature effect that occurs during friction and (or) during the heat treatment process.

An important feature of the developed material is the ability to be strengthened by quenching with subsequent aging, for this the models were heated to a temperature of $600^{\circ} \mathrm{C}$, which lasted for 0.5 hours, then cooled in water, and then held at $450^{\circ} \mathrm{C}$ in the time range from 0 to $16 \mathrm{~h}$., after which a hardness measurement was performed using the Vickers method, the nature of the change in hardness, depending on the aging time, is given in Figure 5.5. As can be seen from the figure, the hardness increases in proportion to the aging time to 10 hours and remains 
practically unchanged, this kind of change of microhardness indicates the passage of the processes of the allocation of secondary phases in the alloy of the bundle. The increase in hardness during the aging process is accompanied by increased strength during bending and reduced cracking.

The given nature of the change in properties is favorable for use in the mechanical seals of centrifugal oil and gas pumps, as the material of the rings will be strengthened during the work due to the temperature released during friction.

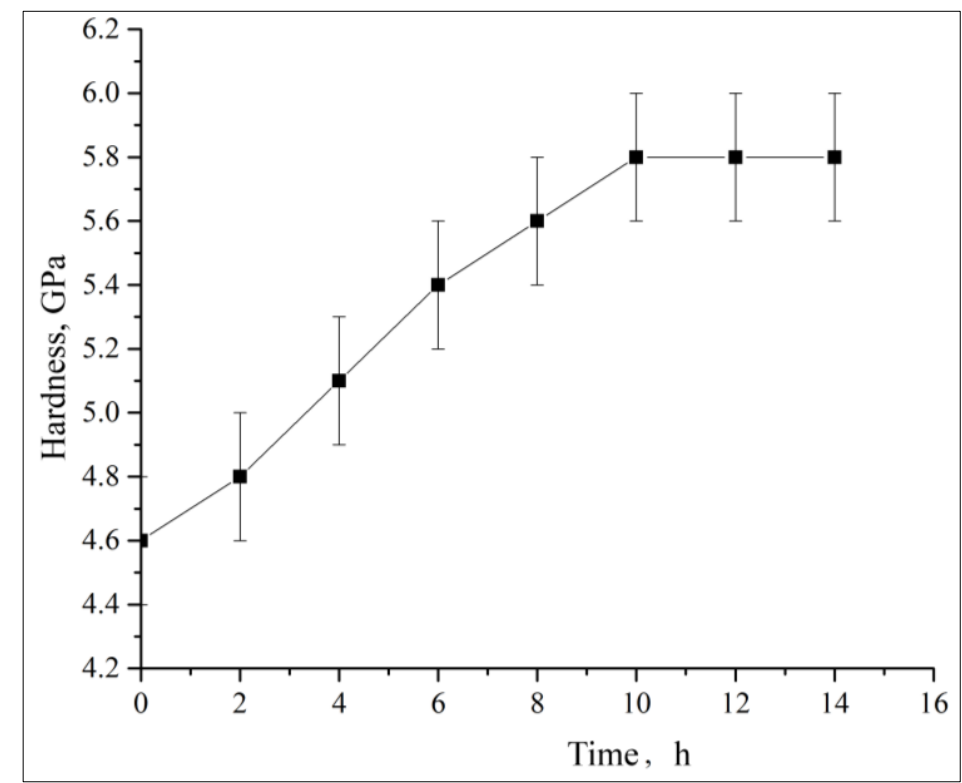

Fig. 5.5. Dependence of composite hardness on the duration of isothermal holding at $400{ }^{\circ} \mathrm{C}$

Table 5.1

Mechanical properties of rings materials based on $\mathrm{Cr}_{3} \mathrm{C}_{2}-$ Cu60Ni20Mn20 composites

\begin{tabular}{|l|c|c|}
\hline \multirow{2}{*}{$\begin{array}{c}\text { Characteristics, designations, units } \\
\text { of measurement }\end{array}$} & \multicolumn{2}{|c|}{ Value } \\
\cline { 2 - 3 } & Before aging & $\begin{array}{c}\text { After aging } \\
400^{\circ} \mathrm{C}\end{array}$ \\
\hline Vickers hardness, $H V, \mathrm{GPa}$ & 480 & 590 \\
\hline Bending strength, $R_{b m}\left(\sigma_{3 \Gamma}\right), \mathrm{MPa}$ & 960 & 1010 \\
\hline Crack resistance, $K_{I C}, \mathrm{MPa} \cdot \mathrm{m}^{1 / 2}$ & 22 & 18 \\
\hline
\end{tabular}

The results of sclerometeric studies show that the hardness of the $\mathrm{Cr}_{3} \mathrm{C}_{2}-\mathrm{Cu} 60 \mathrm{Ni20Mn} 20$ composite (Hs) measured at a load of $100 \mathrm{~N}$ and calculated by the width of the groove (Figure 5.6) by formula (2.26) is $5.19 \mathrm{GPa}$, which closely correlates with the hardness measured by squeezing 
the pyramid. The surface left by the tracker indenter thus contains traces of plastic deformation on two sides of the track. This testifies to high indexes of plasticity of a composite in combination with high hardness.

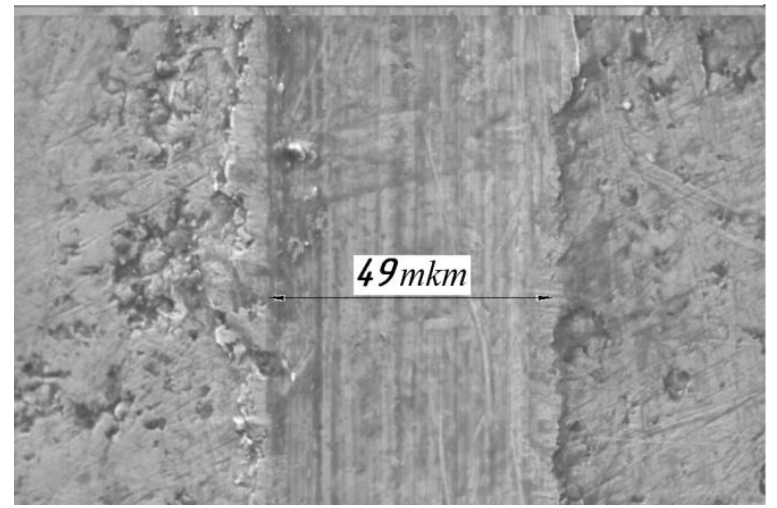

Fig. 5.6. The diamond cone track is left on the surface of $\mathrm{Cr}_{3} \mathrm{C}_{2}-\mathrm{Cu60Ni20Mn20}$ composite after sclerometric studies $(\times 500)$

5.3. Wear-resistant materials of rings based on composites of the $\mathrm{Cr}_{3} \mathrm{C}_{2}-\mathrm{Cu} 60 \mathrm{Ni20Mn20}$ system in conditions of sliding friction on metal according to the disc-plane scheme

The results of tribotests in the conditions of sliding friction on a steel counterbody show that when increasing the specific load, the coefficient of friction is described by a curve with a minimum $(\sim 0.15)$, which is at a pressure $\sim 20 \mathrm{MPa}$. (Fig. 5.7). Further increase of the load leads to an intensive increase both the coefficient of friction and the intensity of wear.

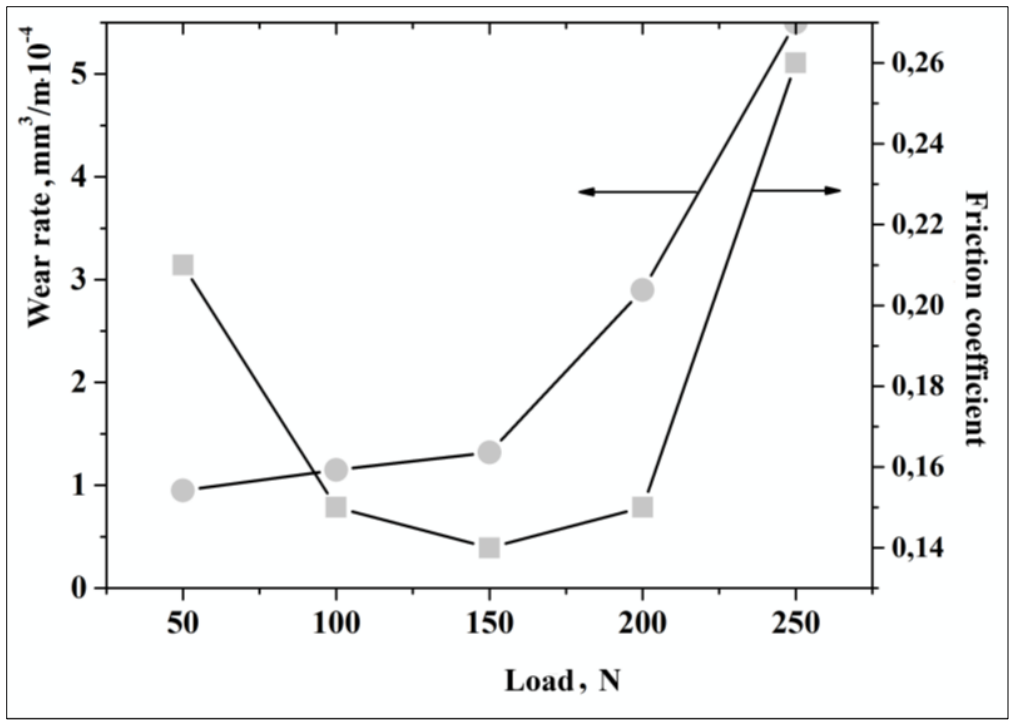

Fig. 5.7. Dependence of the volume intensity of wear and the coefficient of friction in a pair of $\mathrm{Cr}_{3} \mathrm{C}_{2}-\mathrm{Cu} 60 \mathrm{Ni20Mn20-steel} \mathrm{composite}$ 
Thus, in the process of friction of the $\mathrm{Cr}_{3} \mathrm{C}_{2}-\mathrm{Cu} 60 \mathrm{Ni} 20 \mathrm{Mn} 20$ composite on steel, three basic stages can be distinguished:

1. Under load up to $100 \mathrm{~N}$ (pressure $\sim 14 \mathrm{MPa}$ ), the finishing of surfaces, partial deflection of the carbide phase grains and the appearance of microscopic processes;

2. For loads from 100 to $200 \mathrm{~N}$ (pressure from $\sim 14$ to $20 \mathrm{MPa}$ ) is characterized by the appearance of oxide films and the appearance of oxide wear, which contributes to reducing the coefficient of friction;

3. At loads above $200 \mathrm{~N}$ the processes of gripping and intensive thermal wear are developed.

The results of the tribology tests of the developed composites in the conditions of sliding friction without lubrication (Fig. 5.8) show that in the process of friction with an increase in the duration of tests to 1 hour, the friction coefficient linearly decreases by almost 3 times. Consequently, the developed composites are characterized by high running-in ability. This characteristic is especially important for the operation of end sealants, especially when starting and stopping pump units, as there are sharp jumps in temperature that can lead to thermal cracking of rings. This is especially evident when using ceramic rings based on aluminum oxide and silicon carbides. Thus, the developed composites can be offered as substitutes for ceramic materials in a work environment where there is a high risk of dry friction appearance. The low temperature of the $\mathrm{Cr}_{3} \mathrm{C}_{2}-\mathrm{Cu} 60 \mathrm{Ni} 20 \mathrm{Mn} 20$ composites allows not only to use them in the form of monolithic materials, but also to apply coatings on their basis by the method of furnace surfacing on steel billets. This allows you to significantly save materials and simplify the technology of obtaining products.

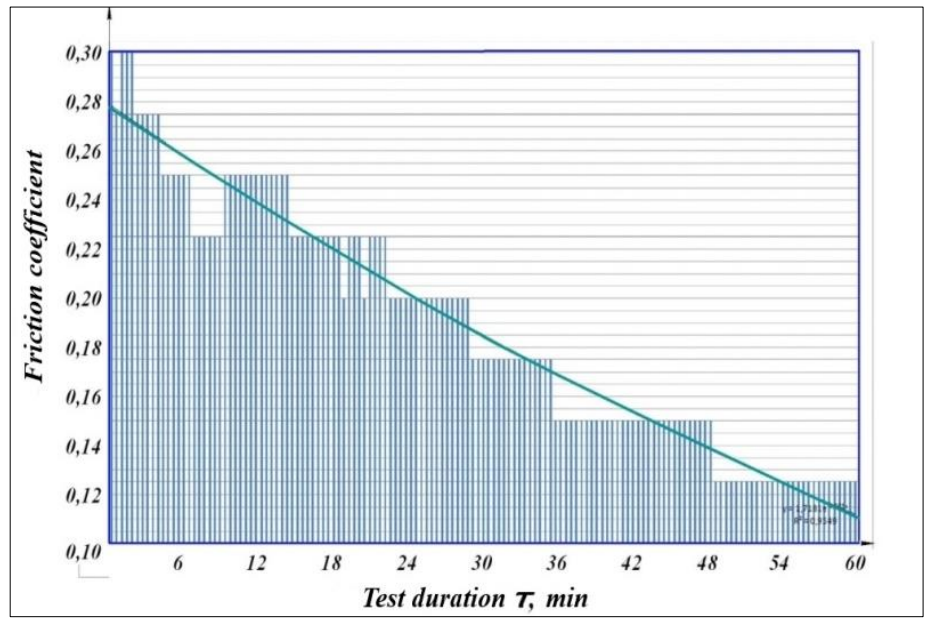

Fig. 5.8. The dependence of the coefficient of friction on the duration of testing in a pair of $\mathrm{Cr}_{3} \mathrm{C}_{2}-\mathrm{Cu} 60 \mathrm{Ni20Mn20}$ composites at a pressure of $0.64 \mathrm{MPa}$ 


\subsection{Wear-resistant materials of rings based on composites}

of the $\mathrm{Cr}_{3} \mathrm{C}_{2}-\mathrm{Cu} 60 \mathrm{Ni20Mn20}$ system in conditions of abrasive wear

The results of the comparative analysis of wear resistance of the developed material under friction on the fixed abrasive (Fig. 5.9) show that its wear resistance is higher compared to traditional high-chromium materials for surfacing. This is due to the expressed heterophase structure of the developed cermet and the high content (66 wt.\%) of the carbide phase, which is sufficiently evenly distributed in the matrix phase.

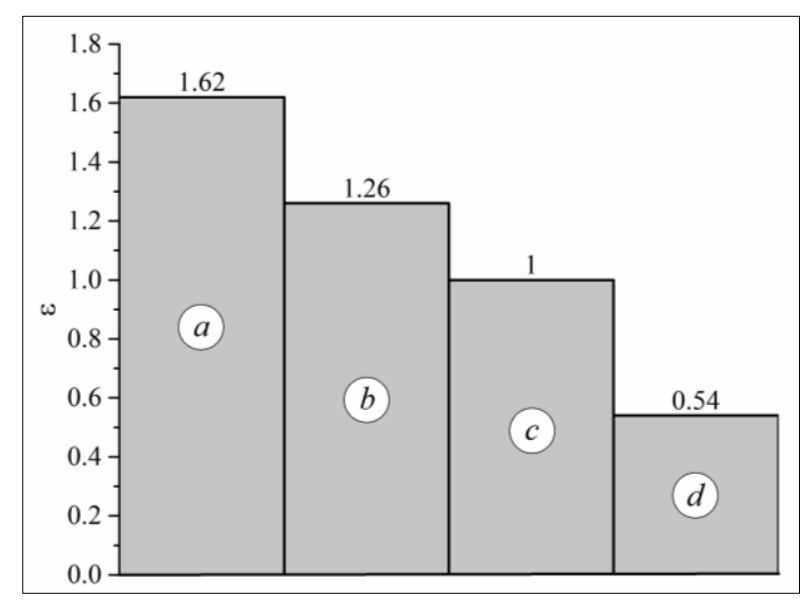

Fig. 5.9. Comparative characteristics of wear resistance of cermet $\mathrm{Cr}_{3} \mathrm{C}_{2}-\mathrm{Cu} 60 \mathrm{Ni20Mn20}$ (a) and some high-chromium materials for surfacing: T-620 (b); T-590 (c); Sormait CA-1 (d)

\subsection{Performance characteristics of mechanical seal rings of oil and gas pumps based on $\mathrm{Cr}_{3} \mathrm{C}_{2}-\mathrm{Cu} 60 \mathrm{Ni20Mn} 20$ composite}

Operational testing of mechanical seal rings was carried out on the basis of the Dolin gas processing plant (Dolinsky gas processing plant) on the line of the gas-friction plant, the scheme of which is shown in fig. 5.10.

Gas Fractionation Unit (HFU) is intended for the separation of a wide fraction of light hydrocarbons into narrow

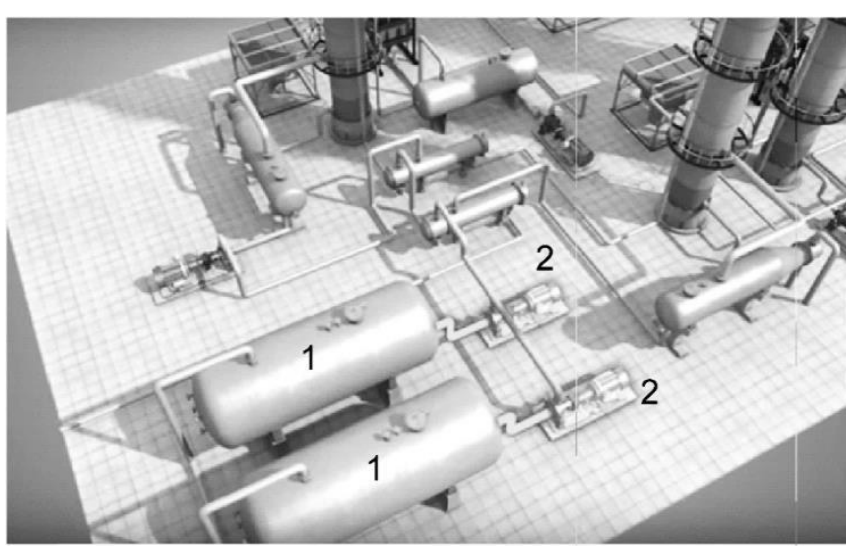

Fig. 5.10. Scheme of gas-friction plant ${ }^{103}$

103 Газофракционирующая установка URL: https://www.youtube.com/ watch?v= zbxzrqrbbmw 
fractions. Their quantity and composition depend on raw materials and technological problems.

HFU is equipped with a line of centrifugal pumps of the brand 4 NG5 $\times 2$. Horizontal electric pump unit of the model 4 NG5 $\times 2$ (Fig. 5.11) has a two-stage centrifugal mechanism and is used for the transfer of a wide fraction of petroleum products and liquefied gases at temperatures from -3 to $200^{\circ} \mathrm{C}$. In addition to these substances, this pump makes it possible to pump liquids that are similar to the above physical chemical indicators (Table 5.2). The pump is equipped with a horizontal housing connector. The impellers are in double-sided position. The specified model of the pump is completed by the electric motor, which belongs to the explosion-proof category $(22 \mathrm{~kW} / 3000 \mathrm{rpm})$. Such pumps are designed for operation in premises where possible explosive gas mixtures, as well as dust with air falling into categories No. 1, 2, 3 on their explosion hazard, as well as groups T1, T2 and T3 in accordance with the current rules of the structure of electrical installations.

Operation of the pump is carried out in accordance with the system of standards for maintenance and repair of technological equipment of facilities for collecting, transporting gas and gas processing plants included in the system of standards of PJSC "Ukrnafta". This system takes over the maintenance and repair of centrifugal pumps. Maintenance (carried out once a month) of the pump includes:

- cleaning and washing of bearings;

- revision and, if necessary, replacement of seals;

- replacing the lubricant with half-mounts;

- steam rinsing of the system of pipelines leading up to the sealing liquid;

- checking the centering of the unit and attaching it to the foundation;

The current $(\mathrm{C})$ repair includes:

- checking the rotor in the casing and actual gaps in the seals;

- replacement of mechanical seal rings;

- control of the state of the rotor and shaft nuts, operating in the bearings of sliding;

- cleaning of pipelines and chambers of water cooling;

- control of the status of elastic elements of the clutch;

- detailed inspection of all components and parts of the pump and elimination of all detected defects;

Average repair (A) includes all work related to the current repair, as well as:

- disassembly of the rotor, inspection of the shaft, measurement of the taper of the seats, operating in the bearings of the slip; 
- rolling and grinding of the shaft;

- replacing the end seal and the bearings of sliding;

- control of the state of parts of the rotor with the replacement of impregnated;

- monitoring the position of the body and measuring vibration before and after stopping.

Major repairs (M) provides, in addition to works that are carried out with an average repair of a fifth wheel:

- inspection of the case by methods of non-destructive testing;

- replacement of working wheels, shafts, sealing rings, earthbugs, bronze on poles, pressure packing sleeves;

- removal of the building from the foundation and rooting of the seats;

- rotation of the pump and measurement of vibration before stopping and after start-up;

Permissible deviation of periodicity of carrying out of repair works is \pm 5 and +20 for current and major repairs, respectively. Repair works in accordance with the system of technological service and repair of technological equipment facilities of collection facilities, transport of gas and gas-fired plants is carried out according to the scheme: M-5 (C-A)-C-M.

The pump housing is made of gray cast iron and 40x stainless steel shaft. Seal shaft is single or double mechanical seal. The centrifugal pumps are connected to the line through the nozzles through the flanged connection (Fig. 5.12).

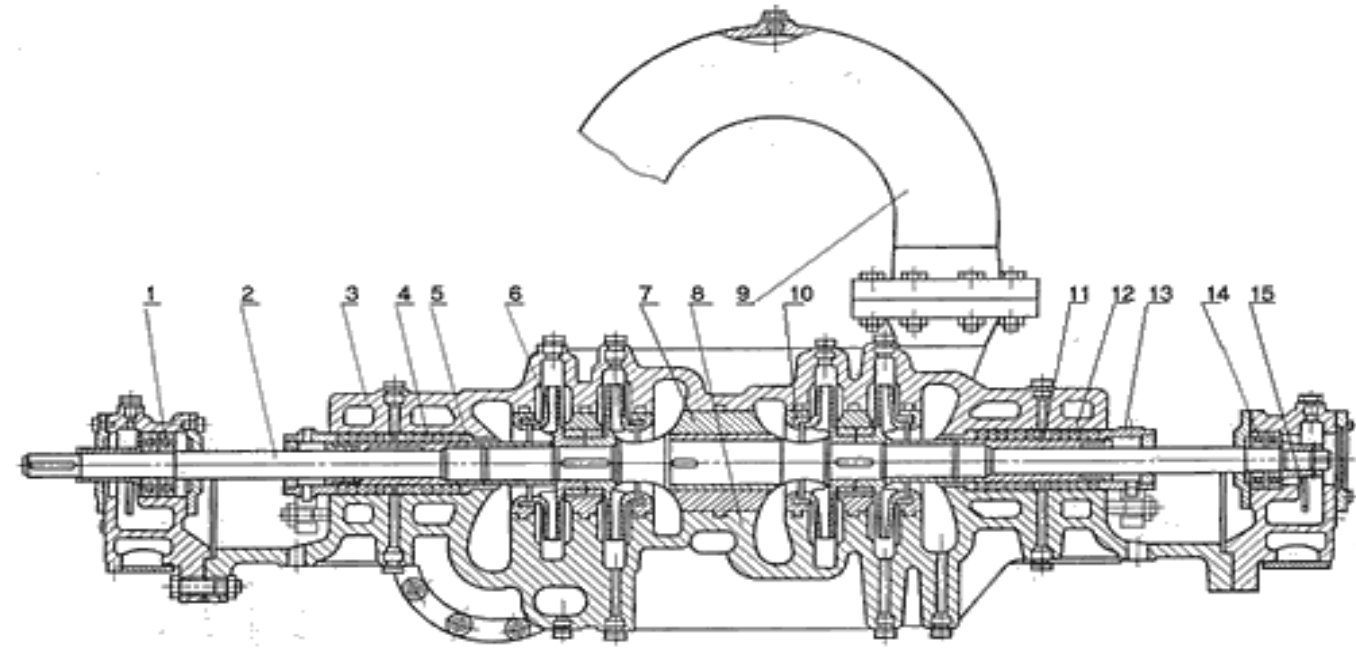

Fig. 5.11. Scheme of a centrifugal pump 4 NG5 $\times 2^{104}$

1 -bearing; 2 -shaft; 3 -body cover; 4 -seals; 5 -protective sleeve; 6 -impeller; 7 -diaphragm; 8 -body; 9 -transient pipe; 10 - ring sealing;

11, 12 -face sealing; 13 - cover; 14 - bearings; 15 - ring for lubrication

${ }^{104}$ Нефтяной насос H URL: http://promglobal.md/pump/product511.html 
Table 5.2

Specifications of a 4 HG $5 \times 2$ centrifugal pumps

\begin{tabular}{|l|c|}
\hline \multicolumn{1}{|c|}{$\begin{array}{c}\text { The name of the characteristic for the diameter } \\
\text { of the impeller is } 194 \mathrm{~mm}\end{array}$} & Value \\
\hline Productivity, $\mathrm{m}^{3} / \mathrm{h}$ & 53 \\
\hline Pressure, $\mathrm{m}$ & 108 \\
\hline Power consumption, $\mathrm{kW}$ & 22 \\
\hline Nominal rotational speed, 1/min & 2950 \\
\hline The average duration of work (years) & 7,5 \\
\hline
\end{tabular}

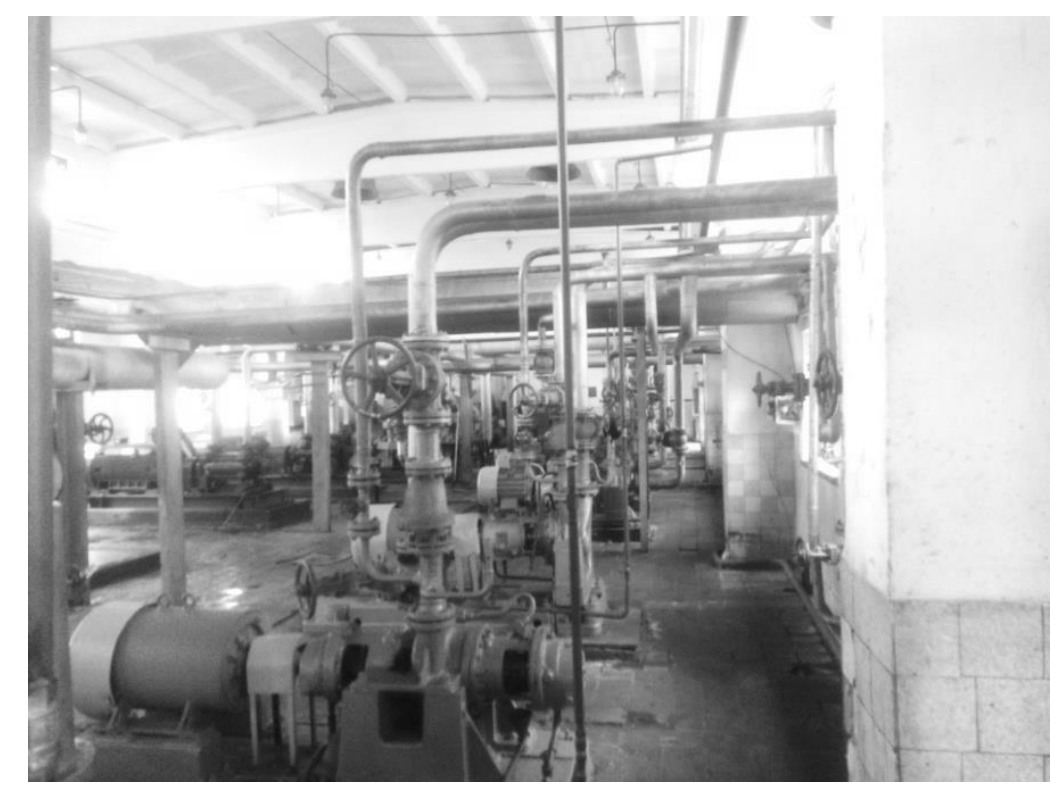

Fig. 5.12. General view of the location of centrifugal pumps at the Dolinsky GPP

HFU manufactures propane-butane, gasoline stable gas, butane and isobutane. The raw material (propane-butane fraction) with the temperature initially enters the container 1 (Fig. 5.10) for water defending. The resulting mixture with centrifugal pumps 2 is pumped through a heat exchanger and at a temperature of $65{ }^{\circ} \mathrm{C}$ enters a column, which is designed to separate the raw material into propane-butane and butanepentane fractions. After this, the cooling of fractions and their transportation is carried out to eliminate excess moisture. After that, the centrifugal pump is used for transportation as automotive gas fuel.

According to the results of industrial tests after the replacement of a pair of ceramic sealing rings from silicon carbide on a combination of metal ceramics $\left(\mathrm{Cr}_{3} \mathrm{C}_{2}-\mathrm{Cu} 60 \mathrm{Ni} 20 \mathrm{Mn} 20\right)-$ ceramics ( $\left.\mathrm{SiC}\right)$, the durability of the results of the planned inspection increased by 2 times compared with the serial ones. 


\section{CONCLUSIONS}

The actual scientific and technical task of increasing durability of friction pairs of mechanical seal rings of centrifugal pumps intended for the pumping of petroleum products is solved in the paper.

1. With a method of powder metallurgy developed a wear-resistant antifriction metal-ceramic composite material on the basis of a chromium carbide and copper-nickel-manganese alloy $\left(\mathrm{Cr}_{3} \mathrm{C}_{2}-\mathrm{Cu} 60 \mathrm{Ni20Mn} 20\right)$ for the manufacture of rings of mechanical seals of oil and gas centrifugal pumps, the use of which can significantly increase their resistance to thermal cracking.

2. Through theoretical calculations and experimental studies, the kinetics of infiltration of the porous ceramic frame from the chromium carbide by the melt of manganese cupronickel has been established, which allows us to make a rational choice of the modes of fabrication of mechanical seal rings from the composite $\mathrm{Cr}_{3} \mathrm{C}_{2}-\mathrm{Cu} 60 \mathrm{Ni} 20 \mathrm{Mn} 20$.

3. A mathematical model of heat propagation at the contact interaction of rings of mechanical seals made from heterogeneous materials has been developed, which enables to predict the temperature gradient in conditions of friction without lubrication, which is characteristic for the working conditions of the sealing of oil and gas industrial centrifugal pumps in the absence of a working environment.

4. It was established that the increase in the durability of the mechanical seals is ensured by the combination of materials of ceramic rings ( $\mathrm{SiC})$ and metal ceramics $\left(\mathrm{Cr}_{3} \mathrm{C}_{2}-\mathrm{Cu} 60 \mathrm{Ni} 20 \mathrm{Mn} 20\right)$.

5. A semi-industrial bench has been developed for the determination of the tribology characteristics of antifriction materials that may be suitable for the manufacture of mechanical seal rings for oil products pumping.

The results of the present research were tested at the Dolin gas processing plant (structural unit of PJSC UKRNAFTA), where it was established that the developed combination of materials can increase the life of the mechanical seals of centrifugal oil and gas pumps by 2 times according to the results of planned inspection.

\section{SUMMARY}

The analysis of the designs of the mechanical seals and the reasons for their failure is carried out, which showed, that one of the main reasons for the failure of the system of the mechanical seals is the brittle destruction of the sealing rings due to the temperature gradient in the friction zone. Thermal cracking appears when dry friction occurs in the initial stages of operation or in emergency situations. 
The main modern types of materials used for the manufacture of rings and their advantages and disadvantages are analyzed. It is shown that under conditions of work, where there is a high risk of dry friction, using of pairs of rings from ceramic materials is not rational. On the basis of this, it is suggested to use metal-ceramic composite with a matrix based on copper-nickel-manganese alloys, which have the ability to be strengthened by aging, for the manufacture of rings. The known composites with a matrix based on copper-nickel-manganese alloys that can be used for the production of rings are analyzed.

The method of obtaining rings of mechanical seals is chosen, namely, infiltration of a porous ceramic prefoms with a melt in a vacuum. Based on the comparative analysis of the properties and cost of ceramic materials for the production of rings, a higher chromium carbide $\left(\mathrm{Cr}_{3} \mathrm{C}_{2}\right)$ was selected.

The technology of fabricating of the seal rings is developed by forming the preforms from the chromium carbide powder and their subsequent melt infiltration. The specified technology allows to receive materials where the content of the ceramic phase is $\sim 60 \%$ by volume.

To estimate the performance of the rings, a comprehensive definition of mechanical and tribology properties of the material was proposed, as well as bench tests on a projected semi-industrial stand, the use of which allows measuring the temperature in the contact area and the coefficient of friction.

An equation that determines the kinetics of impregnation of a porous carbide framework based on its morphological characteristics, as well as the concentration and temperature dependence of the surface tension and the viscosity of the melt, is proposed. The solution of the equation describing the impregnation kinetics using the Lambert function allowed the optimal choice of the duration of infiltration and the size of the $\mathrm{Cr}_{3} \mathrm{C}_{2}$ particles.

The analysis of structure, chemical and phase composition of rings material are carried out by methods of electron microscopy, energy dispersion X-ray spectroscopy and X-ray phase analysis. According to the research results, the distribution and form of $\mathrm{Cr}_{3} \mathrm{C}_{2}$ grains in the composite and its phase composition were determined. On the basis of this, the bulk structure of the composite was modeled, the parameters of which determined the thermophysical properties of the material of the rings.

On the basis of the solution of the Fourier thermal conductivity equation using the integral Laplace transform at given boundary 
conditions an equation was obtained that describes the temperature distribution and temperature differences in the rings contact area. Calculations have shown that for pair $\mathrm{SiC}$ by $\mathrm{Cr}_{3} \mathrm{C}_{2}-\mathrm{Cu} 60 \mathrm{Ni2OMn} 20$ the temperature difference in the contact zone is practically 3 times lower than that of $\mathrm{SiC}$ by $\mathrm{SiC}$. This implies significantly higher resistance to thermal cracking.

The test of metal ceramic materials of rings on frictional heat resistance, which results have found that on the friction surfaces in pair $\mathrm{SiC}$ by $\mathrm{Cr}_{3} \mathrm{C}_{2}-\mathrm{Cu} 60 \mathrm{Ni20Mn} 2 \mathrm{O}$ formed plastic high-copper heat-resistant boundary layer with high antifriction properties. The formation of the boundary layer occurs at sliding speeds from 1 to $5 \mathrm{~m} / \mathrm{s}$ at a pressure equal to $1 \mathrm{MPa}$.

The mechanical properties of the metal-ceramic material of the rings (hardness, crack resistance, durability during bending) were determined and it was established that when the temperature rises at $400^{\circ} \mathrm{C}$ for a period of 10 hours, the hardness and strength of the material increase by $23 \%$ and $17 \%$, respectively. Thus, the high temperature effect that occurs when working the seal seals for the developed composite has a positive effect.

It has been established that the wear resistance of the metal-ceramic material of rings in the conditions of abrasive wear with friction on the fixed abrasive exceeds the wear resistance of the investigated highchromium alloys (T-620, T-590, sormite CS-1), which is explained by the high content of the carbide phase.

The operational tests of rings $\mathrm{SiC}$ by $\mathrm{Cr}_{3} \mathrm{C}_{2}-\mathrm{Cu} 60 \mathrm{Ni20Mn20}$ were carried out at the Dolin gas processing plant (structural unit of Ukrnafta PJSC) on the line of a gas-friction plant intended for the separation of a wide fraction of hydrocarbons into narrow ones. For testing the ring was installed on a pump 4 NG $5 \times 2$, designed for pumping liquefied propane in accordance with the current technological regulations.

Industrial testing of rings has shown that the proposed combination of materials of rings can increase the durability of end seals by 2 times compared with serial ones, in order of data from the planned inspection.

Scientific novelty of the obtained results:

- For the first time was established that the structure of the material of the rings of the mechanical seals, obtained by impregnation of the formed chromium-carbide powder in the melt of manganese metallurgy, consists of bonds on the basis of a solid copper solution $-35 \mathrm{vol} . \%$ and evenly distributed disperse inclusions of chromium carbides $\mathrm{Cr}_{3} \mathrm{C}_{2}$ and $\mathrm{Cr}_{7} \mathrm{C} 3$; 
- The regularities of the contact rings of the seal seals of oil and gas pumps in the conditions of dry friction of slip by the use of the developed semi-industrial booth are established;

- Received the further development the theory of thermal calculations the sliding friction of heterogeneous composite materials in the environment of petroleum products;

- For the first time the tribotechnical characteristics of rings of end seals from metal-ceramic composites of the carbide chromium system manganese melchior in the conditions of dry friction have been determined, which allowed them to be used in conjunction with selfbonded silicon carbide on the pipelines for the transfer of petroleum products.

The practical importance of the results:

- The results obtained in the work allows to make a rational choice of materials for friction of end seals from the standpoint of ensuring their resistance to thermal cracking.

- The technology of manufacturing of seal rings from new metalceramic wear-resistant antifriction materials with high resistance to thermal cracking in the conditions of dry sliding friction that arises at the initial stages of operation of oil and gas pumps is developed.

\section{REFERENCES}

1. OOO «Гидромаш Инжиниринг». URL: http://gme.in.ua/ torcevye-uplotnenija-prichiny-vyhoda-so-stroja-v-nasosah звернення: 15.11.2018).

2. Преимущества торцевого уплотнения над сальниковым. URL: http://www.sealtd.com.ua/tor/advantage.html (дата звернення: 15.12.2018).

3. Jane Wang Q., Yip-Wah Encyclopedia of tribology:monography. New York: Springer-Verlag, 2013. 4139 p.

4. Кондаков Л.А. Уплотнения и уплотнительная техника: справочник [2-е изд.]. Москва : Машиностроение, 1994. 448 с.

5. Майер Э. Торцовые уплотнения (пер. с нем.) : монография. Москва : Машиностроение, 1978. 288 с.

6. Голубев А.И. Торцовые уплотнения вращающихся валов: монография. Москва : Машиностроение, 1978. 212 с.

7. Alan O. Lebek Principles and design of mechanical face seals:monography. New York : Wiley-Interscience, 1991. $764 \mathrm{p}$.

8. Макаров Г.В. Уплотнительные устройства: справочник. Москва : Машиностроение, 1973. 232 с. 
9. Воронков Б.Д. Подшипники сухого трения: монография. Ленинград : Машиностроение. Ленингр. отд., 1979. 224 с.

10. Huebner M.B. Material selection for mechanical seals : Proceedings of the 21st International Pump User's Symposium (Houston, Texas, February-March 2005). Houston, 2005. PP. 127-135.

11. Федорченко И.М., Пугина Л.И. Композиционные спеченные антифрикционные материалы: монография. Киев : Наук. думка, 1980. $404 \mathrm{c}$.

12. Déprez P., Hivart P., Coutouly J. F., Debarre E. Friction and wear studies using Taguchi method: application to the characterization of carbon-silicon carbide tribological couples of automotive water pump seals. Advances in Materials Science and Engineering. London, 2009. №830476. P. 10.

13. Wakely K. Mechanical seals: some developments in face materials. Tribology Int. Amsterdam, 1986. vol.19, №4. PP. 198-203.

14. Müller H.K., Nau B.S. Fluid Sealing Technology: Principles and Applications.monography: NewYork : Marcel Dekker, Inc., 1998. 485 p.

15. Meehanite worldwide specification handbook. URL: http:// www.meehanite.com/Meehanite_Worldwide_Specification_Handbook_v er09.07.2013.pdf (дата звернення: 15.12.2018).

16. Криль Я.А., Флюнт О.Р., Криль Г.В. Матеріалознавство. Тлумачний словник: Т.1. Львів : «Новий світ - 2000», 2012. 476 с.

17. Lai T., Gabriel R., Mayer-Yep L. Improved performance seals for pipeline applications. Lubrication Engineering. Amsterdam, 2003. vol.59, №4. PP. 18-29.

18. ОСТ 26-06-1426-87: Уплотнения валов насосов. Классификация и условные обозначения. URL: http://www.complexdoc.ru/ ntdpdf/481379/uplotneni ya_valov_nasosov_klassifikatsiya_i_uslovnye_ oboznacheniya.pdf (дата звернення: 15.12.2018).

19. Самсонов Г.В., Винницкий И.М. Тугоплавкие соединения: справочник. Москва : Металлургия, 1976. 560 с.

20. Гнесин Г.Г. Бескислородные керамические материалы : монография. Київ : Техніка, 1987. 152 с.

21. Неметаллические тугоплавкие соединения : монография / Т.Я. Косолапова и др. Москва : Металлургия, 1985. 224 с.

22. Сорокин О.Ю., Бубненков И.А., Кошелев Ю.И. и др. Разработка мелкозернистого силицированного графита с улучшенными свойствами. Химия и химическая технология. Иваново, 2012. Т.55, № 6. С. $12-16$. 
23. Материалы уплотняющих колец торцового уплотнения. URL: http://www.sealtd.com.ua/tor/ring_matirial.html (дата звернення: 15.12.2018).

24. Гнилиця І.Д., Криль Я.А., Цап. І.В. Дослідження впливу технологічних параметрів процесу одержання силіційованих графітів для виготовлення кілець торцьових ущільнень відцентрових насосів на їх експлуатаційні властивості. Проблеми трибологї. Хмельницький, 2011. № 3. С. 39-43.

25. Борисова А.Л. Физико-химические свойства окислов: справочник. Москва : Металлургия, 1978. 472 с.

26. Flitney R.K. Seals and sealing handbook, sixth edition. monography: Oxford : Butterworth-Heinemann, 2014. 648 p.

27. Bellosi A., Daurelio G., Chita G. UV laser ablation of alumina ring faces for mechanical seal applications. Applied Physics A. Berlin: Springer Berlin Heidelberg, 1999. Vol. 69, № 1. PP. 539-542.

28. Уманский А.П., Довгаль А.Г., Костенко А.Д. Влияние состава и структуры карбидокремниевых композитов на износостойкость и механизмы их изнашивания при трении в паре с керамическим контртелом. Проблеми трибології. Хмельницький, 2011. № 3. C. $81-88$.

29. Крыль Я.А. Высокотемпературное газостатическое уплотнение нитрида кремния: монография. Киев : Наукова думка, 1993. 141 с.

30. Vila M., Carrapichano J.M., Gomes J.R. Ultra-high performance of DLC-coated Si3N4 rings for mechanical seals. Wear. Amsterdam, 2008. Vol. 256, № 5-6. PP. 940-944.

31. Бондаренко В.П. Триботехнические композиты с высокомодульными наполнителями: монография. Киев : Наукова думка, 1987. 232 c.

32. Nau B.S. Mechanical seal face materials: Proceedings of the Institution of Mechanical Engineers, Part J: Journal of Engineering Tribology (London, March 1). London, 1997. PP. 165-183.

33. Способ изготовления контактных поверхностей торцевых пар трения: Пат. 2169640 РФ. МПКВ22F7/04. № 2000118575/02 ; заявл. 17.07.2000; опубл. 27.06.2001.

34. Composite wear-resistant articles such as face seals: Пат. US3594011 A USA, MПКВ22F7/08 ; заявл. 04.08.1968 ; опублік. 20.07.1971.

35. Method of making composite wear resistant articles, such as face seals: Пат. US3666456 A USA, МПКВ22F7/08 ; заявл. 14.09.1970; опублік. 30.05.1972. 
36. Wei L., Gu B. Q., Feng X., Sun J. J. Research on friction characteristic of end faces of mechanical seals. Advanced Tribology: Proceedings of CIST2008 \& ITS-IFToMM2008. London, 2010. PP. 304-308.

37. ISO 21049/API 682, 2004, Pumps - shaft sealing systems for centrifugal and rotary pumps. URL: https://www.iso.org/standard/ 35625.html (дата звернення: 15.12.2018).

38. Chapter 3 Materials. URL: http://machining.grundfos.com/ media/16605/shaftseal_chapter3.pdf (дата звернення: 15.12.2018).

39. Гнесин Б.А. Возможности управления связностью карбида кремния в композиционных материалах карбид кремния силициды молибдена. Наука и Образование. МГТУ им. Н.Э. Баумана. Электрон. журн. Москва, 2014. №12. С. 941-950.

40. Mayer S., Heinrich Ju.G Processing-microstructure properties relationships of MoSi2-SiC composites. Journal of the European Ceramic Society. Amsterdam, 2002. vol.22, №13. PP. 2357-2363.

41. Suresh Kumar R., Sivakumar D., Venkateswarlu K., Gandhi A.S. Mechanical behavior of molybdenum disilicide reinforced silicon carbide composites. Scripta Materialia. Amsterdam, 2011. Vol. 22, № 13. PP. 838-841.

42. Dean R. S., Anderson C.T. Alloys of manganese-copper and nickel. Am. Soc. Metals Trans. USA, 1941. Vol. 29. PP. 808-812.

43. Belousov V.Ya. Increasing the wear resistance of granular tungsten carbide base composite materials by heat treatment. Soviet materials science. Lviv, 1979. Vol. 15, № 5. PP. 512-514.

44. Masamichi Miki, Shigenori Hori Grain Boundary Reaction in a Cu-Ni-Mn Alloy. Soviet materials science. Sendai, 1982. Vol. 46, № 3. PP. 301-307.

45. Shapiro S., Derek E. Tyler, R. Lanam Phenomenology of precipitation in copper-20 pct nickel-20 pct manganese. Metallurgical Transactions. USA, 1982. Vol. 46, № 3. PP. 301-307.

46. Parravano N. The Ternary Nickel-Manganese-Copper Alloys. Gazz. Chim. Ital. 1912. Vol. 42, № 11. PP. 385-394.

47. Fischer V. The Equilibrium Diagrams for the Ternary Systems. Z. Metallkd. München, 1934. Vol. 26, № 4. PP. 80-82.

48. Zwicker U. Structure of Manganese rich Manganese-CopperNickel Alloys. Z. Metallkd. München, 1951. Vol. 42. PP. 331-335.

49. Chjan B. C. The Study of Ternary Copper Alloys of CopperNickel-Manganese. Izv. Vyss. Uchebn. Zaved. Tsvetn. Metall., 1951. Vol. 42. PP. 331-335. 
50. Glasov V.M. Chemical interaction between nickel and manganese in ternary cooper - based solid solution at various temperatures. Dokl. Acad. Nauk SSSR., 1962. Vol. 144, № 3. PP. 565-568.

51. Rolland J., Whitwham D. Decomposition of Pseudobinary Cu-NiMn Alloys. Compt. Rend. Acad. Sci. Paris, 1970. ser. C. 270, № 3. PP. 1777-1780.

52. Осинцев О.Е., Федоров В.Н. Медь и медные сплавы. Отечественные и зарубежное марки : справочник. Москва : Машиностроение, 2004. 336 с.

53. Watson A., Wagner S., Lysova E., Rokhlin L. Cu-Mn-Ni (CopperManganese-Nickel). Landolt-Börnstein - Group IV Physical Chemistry, 2007. Vol. 11C3. PP. 274-285.

54. Dea R., Long J., Graham T., Mathews C. Age Hardening Cu-NiMn Alloys. Trans. ASM, 1945. Vol. 34.

55. Петросянц А.А., Белоусов В.Я. Саркисов В.С. Повышение долговечности деталей газонефтепромыслового оборудования : монография. Москва : Недра, 1976. 211 с.

56. Патон Б.Е., Дудко Д.А., Максимович Б.И., Агафонов Н.Г. Наплавка намораживанием и заливкой расплавленного присадочного материала. Автоматическая сварка. Киев, 1966. № 11. С. 44-48.

57. Danilov, L.I., Rovenskikh, F.M. Surfacing of charging equipments ofblast Furnaces by a composite alloy. Metallurg. Москва, 1973. № 29. PP. 12-15.

58. Belousov V. Ya. Surfacing of charging equipments ofblast Furnaces by a composite alloy. Soviet materials science. Lviv, 1979. Vol 15, № 5. PP. 512-514.

59. Белоусов В.Я. Долговечность деталей машин с композиционными материалами: монография. Львов : Вища школа, 1984. $180 \mathrm{c}$.

60. Спиридонова I., Сухова О. Композиційні матеріали з металевою матрицею, зміцнені частками Сr-20Ti-10С. Фізика $і$ хімія твердого тіла. Івано-Франківськ, 2002. Т. 3, № 3. С. 503-507.

61. Суховая Е.В. Структурный подход к созданию износостойких композиционных материалов. Сверхтвердые материаль. Киев, 2013. №5. C. 29-38.

62. Whittaker P. Global tungsten prices show signs of stabilising. Powder Metallurgy Review. 2014. vol. 4, №2. P. 20.

63. Мировой рынок вольфрама. URL: http://www.cmmarket.ru/ markets/woworld.htm (дата звернення: 15.12.2018). 
64. Панасюк А.Д., Фоменко В.С., Глебова Г.Г. Стойкость неметаллических материалов в расплава: справочник. Киев : Наукова думка, 1986. $351 \mathrm{c.}$

65. Materials information system. URL: https://setis.ec.europa.eu/mis/ material/chromium (дата звернення: 15.12.2018).

66. Борисова А.Л. Совместимость тугоплавких соединений с металлами и графитом: справочник. Киев : Наукова думка, 1985. 247 с.

67. Гольдшмидт Ж. Дж. Сплавы внедрения (пер. с англ.): монография. Москва : Мир, 1971. 424 с.

68. Шіхаб Таер Абдалвахаб Розроблення технології виготовлення кілець торцевих ущільнень відцентрових насосів із металокерамічних матеріалів на основі карбіду хрому. Науковий вісник ІФНТУНГ. Івано-Франківськ, 2016. № 1 (40). С. 41-49.

69. Butler J.A.V. The thermodynamics of the surfaces of solutions. Proceedings of the Royal Society A, 1932. Vol. 135. PP. 348-375.

70. JMatPro practical software for materials properties. URL: http://www.sentesoftware.co.uk/jmatpro.aspx (дата звернення: 15.12.2018).

71. Найдич Ю.В., Колесниченко Г.А., Лавриненко И.А., Моцак Я.Ф. Пайка и металлизация сверхтвердых инструментальных материалов: монография. Киев : Наукова думка, 1977. 186 с.

72. SmartSEM - Zeiss. URL: http://www.zeiss.com/microscopy/ en_de/products/ microscope-software/smartsem.html (дата звернення: 15.12.2018).

73. INCA Energy - Oxford Instruments Nano Analysis. URL: http://www.oxinst.ru/html/EnergySEM.htm (дата звернення: 15.12.2018).

74. Салтыков С.А. Стереометрическая металлография : монография. Москва : Металлургия, 1976. 271 с.

75. Li K., Gao X. W., Yang W. B., Dai Y. L. Multiple fault diagnosis of down-hole conditions of sucker-rod pumping wells based on Freeman chain code and DCA. Petroleum Science, 2013. Vol. 10, № 3. PP. 347-360.

76. Iwata H., Ukai Y. SHAPE: a computer program package for quantitative evaluation of biological shapes based on elliptic Fourier descriptors. Journal of Heredity, 2002. Vol. 93, № 5. PP. 384-385.

77. Mori T., Tanaka K. Wetting Average stress in the matrix and average elastic energy of materials with misfitting inclusions. Acta metallurgica. 1973. Vol. 21, № 5. PР. 571-574.

78. Присяжнюк П.М., Бурда М.Й. Триботехнічні властивості карбідосталі $\mathrm{NbC-сталь} \mathrm{Гадфільда.} \mathrm{Проблеми} \mathrm{трибології.}$ Хмельницький, 2016. № 1. С. 88-94. 
79. Гинзбург Б.М., Точильников Д.Г. Влияние фуллереносодержащих добавок к фторопластам на их несущую способность при трении. Журнал технической физики. Санкт-Петербург, 2001. T.71 № 2. С. 120-124.

80. РД 50-662-88 Методические указания. Методы экспериментальной оценки фрикционной совместимости материалов трущихся сопряжений URL: https://ohranatruda.ru/ot_biblio/norma/555613/ (дата звернення: 15.12.2018).

81. Прилад для склерометричних досліджень : пат. 70725 Україна. №U201113900 ; заявл. 25.06.11; опубл. 25.06.12, Бюл. № 12.

82. Присяжнюк П.М. Закономірності формування структури та властивостей карбідосталей на основі сталі Гадфільда : дис. ... канд. техн. наук : 05.02.01. Київ, 2014. 159 с.

83. Рацька Н.Б. Підвищення зносостійкості сплаву системи $\mathrm{Nb}-\mathrm{Ti}$ термомодифузійним оксидуванням : дис. ... канд. техн. наук : 05.02.01. Львів, 2015. $140 \mathrm{c.}$

84. Шіхаб Т.А., Криль Я.А., Парайко Ю.І. та ін. Кінетика просочування $\mathrm{Cr} 3 \mathrm{C} 2$ марганцевим мельхіором у процесі отримання керметів. Фізика і хімія твердого тіла. Івано- Франківськ. 2015. № 16 (2). C. 408-412.

85. Scheidegger E. The physics of flow through porous media (3rd ed.): monography. Toronto : University of Toronto Press, 1974. 353 p.

86. Kozeny J. Ueber kapillare Leitung des Wassers im Boden. Sitzungsber Akad. Wiss. Wien. 1927. № 136(2a). PP. 271-306.

87. Butler J.A.V. Thermodynamics of the surfaces of solutions. Proc. Roy. Soc. London, Ser A. London. 1932. № 135. PP. 348-375.

88. Zhongnan Guo, Michael Hindler, Wenxia Yuan, Adolf Mikula The density and surface tension of $\mathrm{In}-\mathrm{Sn}$ and $\mathrm{Cu}-\mathrm{In}-\mathrm{Sn}$ alloys. Monatshefte für Chemie - Chemical Monthly. 2011. Vol. 142, № 6. PP. 579-584.

89. Redlich Otto, Kister A.T. Algebraic representation of thermodynamic properties and the classification of solutions. Ind. Eng. Chem. 1948. Vol.40,№ 2. PP. 345-348.

90. Lu H., Jiang M. Tension and Its Temperature Coefficient for Liquid Metals. J. Phys. Chem. B. 2005. Vol. 109. PP. 15463-15468.

91. Brillo J., Plevachuk Y. Egry I. Surface tension of liquid $\mathrm{Al}-\mathrm{Cu}-\mathrm{Ag}$ ternary alloys. Journal of Materials Science. 2010. Vol. 45, № 19. PP. 5150-5157. 
92. Miettinen J. Thermodynamic description of the $\mathrm{Cu}-\mathrm{Mn}-\mathrm{Ni}$ system at the $\mathrm{Cu}-\mathrm{Ni}$ side. Computer Coupling of Phase Diagrams and Thermochemistry. 2003. № 27. PP. 147-152.

93. Myshko Yu. D., Klibus A. V., Gapchenko M. N., Ishchuk N. Ya. Wetting of some hard alloys by Melchior MNMts20-20. Soviet Powder Metallurgy and Metal Ceramics. 1974. Vol. 13, № 9. PP. 731-734.

94. Prysyazhnyuk, P., Lutsak, D., Vasylyk, A., Thaer S, M. Burda et al. Calculation of surface tension and its temperature dependence for liquid Cu-20Ni-20Mn alloy. Metallurgical and Mining Industry. 2015. № 12, P. 346-350.

95. JMatPro practical software for materials properties URL: http:// www.sentesoftware. co.uk/jmatpro.aspx (дата звернення: 15.12.2018).

96. Шіхаб Т.А., Криль Я.А., Парайко Ю.І. та ін. Кінетика просочування $\mathrm{Cr} 3 \mathrm{C} 2$ марганцевим мельхіором у процесі отримання керметів. Фізика $i$ хімія твердого тіла. Івано-Франківськ, 2015. № 16 (2). C. 408-412.

97. Дубинов А.Е., Дубинова И.Д., Сайков С.К. W-функция Ламберта и ее применение в математических задачах физики. Самаров : ФГУП «РФЯЦ-ВНИИЭФ», 2006. 160 с.

98. Шлапак Л. С. Шіхаб Т., Присяжнюк П.М., Яремій І. П. Формування структури кермету на основі карбіду хрому з мідно-нікелевомаргановою зв'язкою. Металлофизика и новейшие технологии. Київ, 2016. № 38(7). С. 969-980.

99. Присяжнюк П.М. Шіхаб Т., Панчук В.Г Формування структури керметів Сr3С2-МНМц 60-20-20. Фізико-хімічна механіка матеріалів. Львів, 2016. № 52(2). С. 43-47.

100. Kingery W. D. Factors affecting thermal stress resistance of ceramic materials. Journal of the American Ceramic Society. 1955. № 38(1). С. 3-15.

101. Диткин В.А., Прудников А.П. Справочник по операционному исчислению. Москва : Высшая школа, 1965. 466 с.

102. Шлапак Л.С., Шіхаб Т.А., Присяжнюк П.М. та ін. Моделювання поширення тепла у кільцях торцевих ущільнень нафтогазопромислових насосів, виготовлених із композиту на основі карбіду хрому, за умов сухого тертя. Проблеми трибології. Хмельницький, 2018. № 3. С. 53-60.

103. Газофракционирующая установка URL: https://

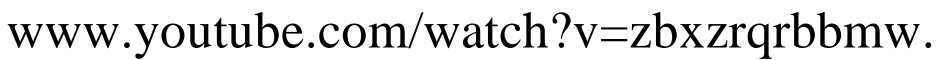

104. Нефтяной насос H URL: http://promglobal.md/pump/product 511.html 
Information about the authors: Prysyazhnyuk Pavlo Mykolaiovych,

Candidate of Technical Sciences, Associate Professor at the Department of Welding Ivano-Frankivsk National Technical University of Oil and Gas 15, Karpatska str., Ivano-Frankivsk, 76019, Ukraine

Shihab Thaer Abdulwahhab, Ph.D, Candidate of Technical Sciences, Lecturer at the Department of Applied Mechanics Engineering Technical College-Middle Technical University of Baghdad Alzafaraniya str., Baghdad, 29132, Iraq

Shlapak Liubomyr Stepanovych, Doctor of Technical Sciences, Head of the Department of Welding Ivano-Frankivsk National Technical University of Oil and Gas, 15, Karpatska str., Ivano-Frankivsk, 76019, Ukraine

Ivanov Oleksandr Oleksandrovych, Researcher Research Institute of Oil and Gas Energy and Ecology, Postgraduate Student Ivano-Frankivsk National Technical University of Oil and Gas 15, Karpatska str., Ivano-Frankivsk, 76019, Ukraine 